Supporting Information

\title{
Cobalt-Catalyzed $\mathrm{C}\left(\mathrm{sp}^{2}\right)-\mathrm{C}\left(\mathrm{sp}^{3}\right)$ Suzuki-Miyaura Cross Coupling
}

\author{
Jacob R. Ludwig, ${ }^{a}$ Eric M. Simmons, ${ }^{b}$ Steven R. Wisniewski, ${ }^{b}$ and Paul J. Chirik ${ }^{\text {* }}$ \\ a. Department of Chemistry, Frick Laboratory, Princeton University, Princeton, NJ 08544, USA \\ b. Chemical Process Development, Bristol Myers Squibb Company, One Squibb Drive, New \\ Brunswick, New Jersey 08903, United States \\ pchirik@princeton.edu
}

\section{Table of Contents}

I. General Considerations $\quad$ S2

II. High Throughput Experimentation $\quad$ S3

$\begin{array}{ll}\text { III. Reaction Optimization } & \text { S11 }\end{array}$

IV. Synthesis of Substrates, Intermediates and Authentic Product Standards S16

V. Co-Catalyzed Suzuki Coupling $\quad$ S23

$\begin{array}{lr}\text { VI. Radical Trap Experiments } & \text { S34 }\end{array}$

VII. Borate Synthesis and Reactivity $\quad$ S38

$\begin{array}{ll}\text { VIII. References } & \text { S43 }\end{array}$

$\begin{array}{ll}\text { IX. NMR Spectra } & \text { S45 }\end{array}$ 


\section{General Considerations}

All air- and moisture-sensitive manipulations were carried out using vacuum line, Schlenk and cannula techniques or in an MBraun inert atmosphere (nitrogen) dry box unless otherwise noted. All glassware was stored in a pre-heated oven prior to use. The solvents used for airand moisture-sensitive manipulations were dried and deoxygenated using literature procedures. ${ }^{1}$ Dimethyl acetamide (DMA, Sigma Aldrich, anhydrous) was brought into the glovebox and stored over $4 \AA$ molecular sieves prior to use. Potassium methoxide (KOMe, Sigma Aldrich, 95\%) was dried under reduced pressure overnight and then brought into the glovebox prior to use. Other solid commercial reagents were dried under reduced pressure and brought into the glovebox prior to use. Liquid commercial reagents were dried/degassed under reduced pressure before being brought into the glovebox prior to use. The following compounds were prepared according to literature procedures: (3-bromobutyl)benzene, ${ }^{2} 4^{\prime}$-phenyl-2,2':6',2"terpyridine ${ }^{3}$ (iPrPNP)CoCl, ${ }^{4}$ methyl 4-(cyclopentylmethyl)benzoate, ${ }^{5}$ and methyl 4-(hex-5-en-1yl)benzoate. ${ }^{6}$

${ }^{1} \mathrm{H}$ NMR spectra were recorded on a Bruker 500 AVANCE spectrometer $(500 \mathrm{MHz})$, a Bruker NB 300 spectrometer (300 MHz), or a Bruker Avance III HD NanoBay $(400 \mathrm{MHz}$ ) spectrometer. ${ }^{13} \mathrm{C}$ NMR spectra were recorded on a Bruker 500 AVANCE spectrometer (126 $\mathrm{MHz}) .{ }^{11} \mathrm{~B}$ NMR spectra were recorded on a Bruker NB 300 spectrometer $(96 \mathrm{MHz})$. All ${ }^{1} \mathrm{H}$ and ${ }^{13} \mathrm{C}$ NMR chemical shifts are reported in ppm relative to $\mathrm{SiMe}_{4}$ using the ${ }^{1} \mathrm{H}$ (chloroform-d: 7.26 ppm; DMSO- $d_{6}: 2.50 \mathrm{ppm}$ ) and ${ }^{13} \mathrm{C}$ (chloroform-d: $77.16 \mathrm{ppm}$; DMSO- $d_{6}: 39.52 \mathrm{ppm}$ ) chemical shifts of the solvent as a standard. ${ }^{1} \mathrm{H}$ NMR data for diamagnetic compounds are reported as follows: chemical shift, multiplicity $(s=$ singlet, $d=$ doublet, $t=$ triplet, $q=$ quartet, $p=$ pentet, $b r$ $=$ broad, $\mathrm{m}=$ multiplet, app $=$ apparent, obsc $=$ obscured $)$, coupling constants $(\mathrm{Hz})$, integration . Elemental analyses were performed at Robinson Microlit Laboratories, Inc., in Ledgewood, NJ. Solid-state magnetic moments were determined using a Johnson Matthey Magnetic Susceptibility Balancethat was calibrated with $\mathrm{HgCo}(\mathrm{SCN}) 4$. 
GC-FID analyses were performed using a Shimadzu GC-2010 gas chromatograph equipped with a Shimadzu AOC-20s autosampler and a Shimadzu SHRXI-5MS capillary column (15m x $250 \mu \mathrm{m})$. The instrument was set to an injection volume of $1 \mu \mathrm{L}$, an inlet split ratio of $20: 1$, and inlet and detector temperatures of $250{ }^{\circ} \mathrm{C}$ and $275^{\circ} \mathrm{C}$, respectively. UHP-grade S3 helium was used as carrier gas with a flow rate of $1.82 \mathrm{~mL} / \mathrm{min}$. Typically, the temperature program used for the analyses was as follows: $60^{\circ} \mathrm{C}$, isothermal $1 \mathrm{~min} ; 15^{\circ} \mathrm{C} / \mathrm{min}$ to $250{ }^{\circ} \mathrm{C}$, isothermal $2 \mathrm{~min}$. GC-FID yield was based on a linear calibration curve (minimum of 5 points) using dodecane as an internal standard. GC-MS analyses were performed on an Agilent 7890A Gas Chromatograph equipped with an Agilent 5975C Mass Selective Detector. High-resolution mass spectra were obtained at Princeton University mass spectrometry facilities using an Agilent 6230 TOF LC/MS with a time-of-flight mass analyzer. Infrared spectroscopy was conducted on a Thermo-Nicolet 6700 FT-IR spectrometer. Column chromatography was performed on SiliaFlash P60 (230-400mesh) silica gel from SiliCycle and Thin layer chromatography (TLC) was performed using aluminum-backed plates pre-coated with silica gel and a fluorescent indicator for visualization upon UV irradiation.

\section{High Throughput Experimentation}

\section{General procedure for HTE studies}

Microscale high-throughput experiments were carried out in an $\mathrm{N}_{2}$-filled glovebox. A 96-well reaction block was loaded with $1 \mathrm{~mL}$ glass vials containing appropriate ligand $(0.5 \mu \mathrm{mol}$ for bidentate ligands, $1.0 \mu \mathrm{mol}$ for monodentate ligands). A solution of $\mathrm{CoCl}_{2} \cdot 6 \mathrm{H}_{2} \mathrm{O}(0.010 \mathrm{M}$ in THF) was added to each vial. The resulting mixtures were aged for 20 min and then concentrated to dryness using a Genevac vacuum centrifuge. A solution of KHMDS (0.15 M in THF) was added to each vial, and the resulting mixtures were again concentrated to dryness using a Genevac. A micro stir bar was charged to each vial, then a solution of the alkyl bromide, aryl boronate ester and alcohol in the appropriate solvent were added to each vial. The reaction 
block was sealed under $\mathrm{N}_{2}$ with a sheet of PFA film, two rubber mats and a metal lid. The block was removed from the glovebox, placed in an orbital shaker, agitated at 300 RPM and heated to $60{ }^{\circ} \mathrm{C}$ on a hotplate for $16 \mathrm{~h}$. After cooling to room temperature, the block was unsealed and a solution of internal standard in $\mathrm{MeCN}$ was added to crude the reaction mixtures. The reaction mixtures were further diluted with 80:20 MeCN:water, then filtered (0.7 $\mu \mathrm{m}$ PPE 96-well filter microplate, Agilent 200937-100) and analyzed by UPLCMS on an Agilent Poroshell 120 EC-C18 column $(2.1 \times 50 \mathrm{~mm}, 1.9 \mu \mathrm{m})$; solvent A: 5:95 acetonitrile:water with $0.05 \%$ TFA, solvent $B$ : 95:5 acetonitrile:water with $0.05 \%$ TFA; gradient from 0\% B to $100 \%$ B over 2.0 min then $100 \%$ B for $0.5 \mathrm{~min}$, flow rate $1.0 \mathrm{~mL} / \mathrm{min}$, oven temperature $40{ }^{\circ} \mathrm{C}$, detection by UV at $220 \mathrm{~nm}$ and low-resolution mass spectrometry detection (positive ion mode) with a Shimadzu LCMS-2020 mass spectrometer. 
<smiles>CC(C)(C)c1ccnc(-c2cc(C(C)(C)C)ccn2)c1</smiles>

tB-BiPy<smiles>c1ccc(-c2ccnc3c2ccc2c(-c4ccccc4)ccnc23)cc1</smiles>

BPhen<smiles>Cc1cnc2c(ccc3c(C)c(C)cnc32)c1C</smiles>

$\mathrm{Me}_{4}$-Phen<smiles>c1cc(C2=NCCO2)nc(C2=NCCO2)c1</smiles>

PyBox<smiles>CC(C)[C@H]1COC(c2cccc(C3=N[C@@H](C(C)C)CO3)n2)=N1</smiles>

iPr-PyBox-R<smiles>CC(C)(C1=N[C@@H](Cc2ccccc2)CO1)C1=N[C@@H](Cc2ccccc2)CO1</smiles>

Bn MeBox-R<smiles>CN(CCC(C)(C)C)[C@H]1CCCC[C@H]1NCCC(C)(C)C</smiles>

-2 $\mathrm{HCl}$

DMDtHexCyDA HCI<smiles>c1ccc(C[C@@H]2COC(C3=N[C@H](Cc4ccccc4)CO3)=N2)cc1</smiles>

Bn-BiOX-s<smiles>N[C@@H]1CCCC[C@H]1O</smiles>

trans-2 $\mathrm{NH}_{2}-\mathrm{CyOH}-\mathrm{rac} \mathrm{HCl}$<smiles>c1cc(C2=N[C@H]3c4ccccc4C[C@H]3O2)nc(C2=N[C@@H]3c4ccccc4C[C@H]3O2)c1</smiles>

InPyBox-R<smiles>Nc1ccc2ccccc2c1-c1c(N)ccc2ccccc12</smiles>

BINAM- $R$<smiles>N#C/C(C1=N[C@@H](c2ccccc2)CO1)=C1/NC(c2ccccc2)CO1</smiles>

Ph CNBox-S<smiles>CC(C)(C1=N[C@@H]2c3ccccc3C[C@H]2O1)C1=N[C@@H]2c3ccccc3C[C@H]2O1</smiles>

Indabox-RS<smiles>CC(C)(C)[C@H]1COC(c2ccc(C(F)(F)F)cn2)=N1</smiles>

5-CF 3 -PyOX-tB-S<smiles>c1ccc(C2CCCN2)nc1</smiles>

PyrPyrrole

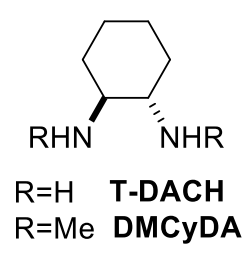

${ }_{\mathrm{N}}^{\mathrm{NHPh}}$

$\mathrm{PhNCH}_{2}$-Pyrrolidine-S<smiles>CN(C)[C@@H]1CCCC[C@H]1N(C)C</smiles>

TMCyDA-RR

\section{$\mathrm{R}_{1}=\mathrm{R}_{2}=\mathrm{Me}$ DMDPEN-SS \\ $\mathrm{R}_{1}=\mathrm{H}, \mathrm{R}_{2}=\mathrm{Ts}$ TsDPEN-SS}<smiles>C1CNC([C@@H]2CCCN2)C1</smiles>

Bipyrrolidine-R

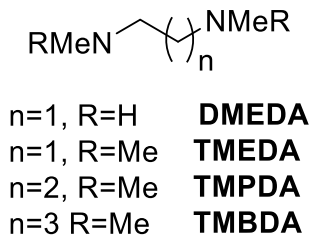<smiles>O=C(O)C1CCCN1</smiles>

PR-L<smiles>N[C@@H]1c2ccccc2C[C@H]1O</smiles>

Aminoindanol-RS

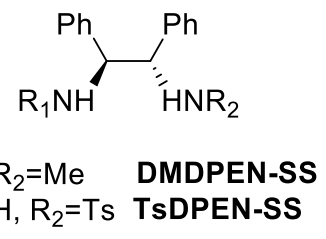

2-PyrMeOH-R<smiles>OC[C@H]1CCCN1</smiles>

2-PyrMeOH-R<smiles>Oc1cccc2cccnc12</smiles>

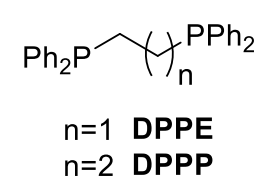

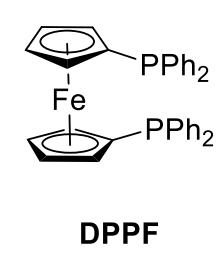<smiles>CN[C@@H](C)[C@H](O)c1ccccc1</smiles>

Ephedrine-RS HCl

Figure S1. Ligands tested in HTE studies. 
Table S1. Results of HTE ligand survey.<smiles>O=C(c1ccccc1)N1CCC(Br)CC1</smiles>

1.5 equiv
$5 \mathrm{~mol} \% \mathrm{CoCl}_{2} \cdot 6 \mathrm{H}_{2} \mathrm{O}$

$5 \mathrm{~mol} \%$ ligand

1.5 equiv KHMDS

2 equiv $\mathrm{MeOH}$ or $\mathrm{EtOH}$

THF or DMAc $(0.1 \mathrm{M})$ $60{ }^{\circ} \mathrm{C}, 16 \mathrm{~h}$<smiles>CC(=O)N1CCC(c2ccccc2)CC1</smiles>
$\mathrm{N}^{-\mathrm{Cbz}}$

\begin{tabular}{|c|c|c|c|c|c|c|c|c|c|}
\hline \multicolumn{2}{|l|}{ Ligand } & \multirow{2}{*}{$\begin{array}{c}\text { Base } \\
\text { Name }\end{array}$} & Solvent & \multirow{2}{*}{$\begin{array}{c}\text { C-C pdt. } \\
R A P\end{array}$} & \multirow{2}{*}{$\begin{array}{c}\text { Alkyl-Br } \\
R A P\end{array}$} & \multirow{2}{*}{$\begin{array}{c}\text { Pdt.: } \\
\text { Int. Std. }\end{array}$} & \multirow{2}{*}{$\begin{array}{c}\text { Cbz-Pip-H } \\
R A P\end{array}$} & \multirow{2}{*}{$\begin{array}{c}\text { alkene } \\
R A P\end{array}$} & \multirow{2}{*}{$\begin{array}{c}\text { Pdt.: } \\
\text { Impurities }\end{array}$} \\
\hline Name & L/M & & Name & & & & & & \\
\hline tB-BiPy & 1.0 & KOMe & THF & $11.73 \%$ & $60.00 \%$ & 0.30 & & $28.27 \%$ & $29: 71$ \\
\hline tB-BiPy & 1.0 & KOMe & DMAc & $5.63 \%$ & $20.62 \%$ & 0.12 & & $73.75 \%$ & $7: 93$ \\
\hline tB-BiPy & 1.0 & KOEt & THF & $6.09 \%$ & $67.81 \%$ & 0.13 & $2.45 \%$ & $23.65 \%$ & $19: 81$ \\
\hline tB-BiPy & 1.0 & KOEt & DMAc & $7.74 \%$ & $14.26 \%$ & 0.17 & & $78.00 \%$ & $9: 91$ \\
\hline iPr-PyBox-R & 1.0 & KOMe & THF & $3.27 \%$ & $73.59 \%$ & 0.07 & & $23.13 \%$ & $12: 88$ \\
\hline iPr-PyBox-R & 1.0 & KOEt & DMAc & $3.08 \%$ & $23.88 \%$ & 0.06 & & $73.04 \%$ & $4: 96$ \\
\hline Ph CNBox-S & 1.0 & KOMe & THF & $3.65 \%$ & $71.46 \%$ & 0.08 & $3.31 \%$ & $21.58 \%$ & $13: 87$ \\
\hline Ph CNBox-S & 1.0 & KOMe & DMAc & $5.85 \%$ & $18.16 \%$ & 0.12 & & $75.99 \%$ & $7: 93$ \\
\hline Ph CNBox-S & 1.0 & KOEt & THF & $3.78 \%$ & $62.52 \%$ & 0.08 & $17.79 \%$ & $15.91 \%$ & $10: 90$ \\
\hline Ph CNBox-S & 1.0 & KOEt & DMAC & $6.88 \%$ & $12.68 \%$ & 0.14 & & $80.44 \%$ & $8: 92$ \\
\hline Indabox-RS & 1.0 & KOEt & DMAC & $11.23 \%$ & $32.92 \%$ & 0.23 & $2.27 \%$ & $53.58 \%$ & $17: 83$ \\
\hline Bn-BiOX-S & 1.0 & KOMe & THF & & $74.73 \%$ & & & $25.27 \%$ & \\
\hline Bn-BiOX-S & 1.0 & KOMe & DMAc & $3.26 \%$ & $19.80 \%$ & 0.06 & & $76.95 \%$ & $4: 96$ \\
\hline $\mathrm{Bn}-\mathrm{BiOX}-\mathrm{S}$ & 1.0 & KOEt & THF & & $76.14 \%$ & & & $23.86 \%$ & \\
\hline Bn-BiOX-S & 1.0 & KOEt & DMAc & $4.60 \%$ & $15.00 \%$ & 0.09 & $1.58 \%$ & $78.82 \%$ & $5: 95$ \\
\hline Bn MeBox-R & 1.0 & KOMe & $\mathrm{THF}$ & & $74.19 \%$ & & & $25.81 \%$ & \\
\hline Bn MeBox-R & 1.0 & KOMe & DMAc & $15.72 \%$ & $30.73 \%$ & 0.35 & $2.69 \%$ & $50.85 \%$ & $23: 77$ \\
\hline Bn MeBox-R & 1.0 & KOEt & THF & $1.68 \%$ & $80.17 \%$ & 0.03 & & $18.15 \%$ & $8: 92$ \\
\hline Bn MeBox-R & 1.0 & KOEt & DMAC & $2.41 \%$ & $36.73 \%$ & 0.05 & $1.62 \%$ & $59.25 \%$ & $4: 96$ \\
\hline PyrPyrrole & 1.0 & KOMe & THF & & $78.29 \%$ & & & $21.71 \%$ & \\
\hline Me4-Phen & 1.0 & KOMe & THF & $9.12 \%$ & $57.97 \%$ & 0.20 & $2.98 \%$ & $29.93 \%$ & $22: 78$ \\
\hline Me4-Phen & 1.0 & KOMe & DMAc & $17.46 \%$ & $28.06 \%$ & 0.42 & $3.41 \%$ & $51.07 \%$ & $24: 76$ \\
\hline Me4-Phen & 1.0 & KOEt & THF & $2.40 \%$ & $28.28 \%$ & 0.05 & $8.90 \%$ & $60.42 \%$ & $3: 97$ \\
\hline Me4-Phen & 1.0 & KOEt & DMAC & $2.06 \%$ & $28.70 \%$ & 0.04 & $3.85 \%$ & $65.38 \%$ & $3: 97$ \\
\hline DMCyDA & 1.0 & KOMe & THF & $13.52 \%$ & $58.88 \%$ & 0.27 & $11.85 \%$ & $15.75 \%$ & $33: 67$ \\
\hline DMCyDA & 1.0 & KOMe & DMAc & $4.45 \%$ & $24.23 \%$ & 0.08 & $6.11 \%$ & $65.21 \%$ & $6: 94$ \\
\hline DMCyDA & 1.0 & KOEt & THF & $29.40 \%$ & $46.98 \%$ & 0.59 & $11.00 \%$ & $12.61 \%$ & $55: 45$ \\
\hline DMCyDA & 1.0 & KOEt & DMAC & $16.70 \%$ & $20.59 \%$ & 0.31 & $8.40 \%$ & $54.32 \%$ & $21: 79$ \\
\hline 5-CF3-PyOX-iBu-R & 1.0 & KOMe & THF & & $79.38 \%$ & & & $20.62 \%$ & \\
\hline 5-CF3-PyOX-iBu-R & 1.0 & KOMe & DMAc & $2.46 \%$ & $23.90 \%$ & 0.05 & & $73.64 \%$ & $3: 97$ \\
\hline 5-CF3-PyOX-iBu-R & 1.0 & KOEt & THF & & $83.80 \%$ & & & $16.20 \%$ & \\
\hline 5-CF3-PyOX-iBu-R & 1.0 & KOEt & DMAc & $3.47 \%$ & $22.53 \%$ & 0.07 & & $74.00 \%$ & $4: 96$ \\
\hline PyBOX & 1.0 & KOMe & THF & & $77.73 \%$ & & & $22.27 \%$ & \\
\hline PyBOX & 1.0 & KOMe & DMAc & $3.22 \%$ & $27.42 \%$ & 0.07 & $2.55 \%$ & $66.81 \%$ & $4: 96$ \\
\hline PyBOX & 1.0 & KOEt & THF & & $76.29 \%$ & & & $23.71 \%$ & \\
\hline PyBOX & 1.0 & KOEt & DMAC & $3.59 \%$ & $23.71 \%$ & 0.08 & $2.51 \%$ & $70.20 \%$ & $5: 95$ \\
\hline
\end{tabular}




\begin{tabular}{|c|c|c|c|c|c|c|c|c|c|}
\hline \multicolumn{2}{|l|}{ Ligand } & \multirow{2}{*}{$\begin{array}{c}\text { Base } \\
\text { Name }\end{array}$} & \multirow{2}{*}{$\begin{array}{c}\text { Solvent } \\
\text { Name }\end{array}$} & \multirow{2}{*}{$\begin{array}{c}\text { C-C pdt. } \\
R A P\end{array}$} & \multirow{2}{*}{$\begin{array}{c}\text { Alkyl-Br } \\
R A P\end{array}$} & \multirow{2}{*}{$\begin{array}{c}\text { Pdt.: } \\
\text { Int. Std. }\end{array}$} & \multirow{2}{*}{$\begin{array}{c}\text { Cbz-Pip-H } \\
R A P\end{array}$} & \multirow{2}{*}{$\begin{array}{c}\text { alkene } \\
R A P\end{array}$} & \multirow{2}{*}{$\begin{array}{c}\text { Pdt:: } \\
\text { Impurities }\end{array}$} \\
\hline Name & L/M & & & & & & & & \\
\hline InPyBox-R & 1.0 & KOMe & THF & & $76.58 \%$ & & & $23.42 \%$ & \\
\hline InPyBox-R & 1.0 & KOMe & DMAC & & $33.07 \%$ & & $2.14 \%$ & $64.79 \%$ & \\
\hline InPyBox-R & 1.0 & KOEt & THF & & $79.52 \%$ & & & $20.48 \%$ & \\
\hline InPyBox-R & 1.0 & KOEt & DMAc & & $32.77 \%$ & & $2.68 \%$ & $64.55 \%$ & \\
\hline trans-2NH2-CyOH-rac. $\mathrm{HCl}$ & 1.0 & KOMe & THF & $1.73 \%$ & $79.47 \%$ & 0.04 & & $18.81 \%$ & $8: 92$ \\
\hline trans-2NH2-CyOH-rac. $\mathrm{HCl}$ & 1.0 & KOMe & DMAC & $4.44 \%$ & $30.06 \%$ & 0.09 & $2.39 \%$ & $63.12 \%$ & $6: 94$ \\
\hline trans-2NH2-CyOH-rac. $\mathrm{HCl}$ & 1.0 & KOEt & THF & & $82.80 \%$ & & & $17.20 \%$ & \\
\hline trans-2NH2-CyOH-rac. $\mathrm{HCl}$ & 1.0 & KOEt & DMAC & $2.78 \%$ & $28.14 \%$ & 0.06 & $2.40 \%$ & $66.68 \%$ & $4: 96$ \\
\hline 2-PyrMeOH-S & 1.0 & KOMe & THF & & $79.65 \%$ & & & $20.35 \%$ & \\
\hline 2-PyrMeOH-S & 1.0 & KOMe & DMAc & $2.69 \%$ & $27.32 \%$ & 0.06 & $2.07 \%$ & $67.92 \%$ & $4: 96$ \\
\hline 2-PyrMeOH-S & 1.0 & KOEt & THF & & $82.95 \%$ & & & $17.05 \%$ & \\
\hline 2-PyrMeOH-S & 1.0 & KOEt & DMAc & $2.46 \%$ & $20.88 \%$ & 0.05 & $2.37 \%$ & $74.28 \%$ & 3:97 \\
\hline QNOL & 1.0 & KOMe & THF & $9.98 \%$ & $63.36 \%$ & 0.23 & $8.98 \%$ & $17.67 \%$ & $27: 73$ \\
\hline QNOL & 1.0 & KOMe & DMAc & $5.36 \%$ & $25.11 \%$ & 0.11 & $2.82 \%$ & $66.70 \%$ & $7: 93$ \\
\hline QNOL & 1.0 & KOEt & THF & & $83.66 \%$ & & & $16.34 \%$ & \\
\hline QNOL & 1.0 & KOEt & DMAC & $16.36 \%$ & $20.16 \%$ & 0.30 & $7.98 \%$ & $55.50 \%$ & $20: 80$ \\
\hline DPPE & 1.0 & KOMe & THF & $2.01 \%$ & $81.67 \%$ & 0.06 & $4.26 \%$ & $12.06 \%$ & $11: 89$ \\
\hline DPPE & 1.0 & KOMe & DMAc & $6.23 \%$ & $71.10 \%$ & 0.24 & $5.11 \%$ & $17.56 \%$ & $22: 78$ \\
\hline DPPE & 1.0 & KOEt & THF & $9.96 \%$ & $68.91 \%$ & 0.27 & $12.86 \%$ & $8.26 \%$ & $32: 68$ \\
\hline DPPE & 1.0 & KOEt & DMAC & $2.59 \%$ & $61.36 \%$ & 0.07 & $7.19 \%$ & $28.87 \%$ & $7: 93$ \\
\hline DPPP & 1.0 & KOMe & THF & $10.16 \%$ & $72.88 \%$ & 0.30 & $3.43 \%$ & $13.54 \%$ & $37: 63$ \\
\hline DPPP & 1.0 & KOMe & DMAc & $8.10 \%$ & $41.05 \%$ & 0.18 & $6.10 \%$ & $44.75 \%$ & $14: 86$ \\
\hline DPPP & 1.0 & KOEt & THF & $2.11 \%$ & $61.02 \%$ & 0.05 & $29.33 \%$ & $7.53 \%$ & $5: 95$ \\
\hline DPPP & 1.0 & KOEt & DMAc & $4.76 \%$ & $41.71 \%$ & 0.10 & $9.01 \%$ & $44.52 \%$ & $8: 92$ \\
\hline DPPF & 1.0 & KOMe & THF & $1.97 \%$ & $61.16 \%$ & 0.05 & & $36.88 \%$ & $5: 95$ \\
\hline DPPF & 1.0 & KOMe & DMAC & $9.02 \%$ & $25.02 \%$ & 0.20 & $2.91 \%$ & $63.05 \%$ & $12: 88$ \\
\hline DPPF & 1.0 & KOEt & THF & & $70.18 \%$ & & & $29.82 \%$ & \\
\hline DPPF & 1.0 & KOEt & DMAC & $1.50 \%$ & $52.70 \%$ & 0.04 & $2.63 \%$ & $43.17 \%$ & 3:97 \\
\hline PEt3 HBF4 & 2.0 & KOMe & THF & & $82.88 \%$ & & & $17.12 \%$ & \\
\hline PEt3 HBF4 & 2.0 & KOMe & DMAc & $3.18 \%$ & $32.91 \%$ & 0.06 & $5.19 \%$ & $58.71 \%$ & 5:95 \\
\hline PEt3 HBF4 & 2.0 & KOEt & THF & & $81.22 \%$ & & $2.01 \%$ & $16.78 \%$ & \\
\hline PEt3 HBF4 & 2.0 & KOEt & DMAC & $4.42 \%$ & $31.83 \%$ & 0.09 & $7.26 \%$ & $56.49 \%$ & $6: 94$ \\
\hline PPh3 & 2.0 & KOMe & THF & & $74.51 \%$ & & & $25.49 \%$ & \\
\hline PPh3 & 2.0 & KOMe & DMAC & $2.09 \%$ & $27.06 \%$ & 0.04 & $3.52 \%$ & $67.33 \%$ & $3: 97$ \\
\hline PPh3 & 2.0 & KOEt & THF & & $79.00 \%$ & & & $21.00 \%$ & \\
\hline PPh3 & 2.0 & KOEt & DMAc & $3.93 \%$ & $19.05 \%$ & 0.08 & $3.05 \%$ & $73.98 \%$ & $5: 95$ \\
\hline Xantphos & 1.0 & KOMe & THF & & $76.90 \%$ & & & $23.10 \%$ & \\
\hline Xantphos & 1.0 & KOMe & DMAC & & $26.59 \%$ & & & $73.41 \%$ & \\
\hline Xantphos & 1.0 & KOEt & THF & & $77.80 \%$ & & & $22.20 \%$ & \\
\hline Xantphos & 1.0 & KOEt & DMAC & & $23.55 \%$ & & & $76.45 \%$ & \\
\hline DPPBz & 1.0 & KOMe & THF & & $70.13 \%$ & & $13.53 \%$ & $16.34 \%$ & \\
\hline DPPBz & 1.0 & KOMe & DMAC & & $81.96 \%$ & & $2.34 \%$ & $15.70 \%$ & \\
\hline DPPBz & 1.0 & KOEt & THF & & $66.20 \%$ & & $18.84 \%$ & $14.97 \%$ & \\
\hline \multirow[t]{5}{*}{ DPPBz } & 1.0 & KOEt & DMAc & $0.91 \%$ & $73.50 \%$ & 0.04 & $3.94 \%$ & $21.64 \%$ & $3: 97$ \\
\hline & & KOMe & THF & & $74.04 \%$ & & & $25.96 \%$ & \\
\hline & & KOMe & DMAC & $2.66 \%$ & $23.50 \%$ & 0.05 & & $73.83 \%$ & $3: 97$ \\
\hline & & KOEt & THF & & $79.17 \%$ & & & $20.83 \%$ & \\
\hline & & KOEt & DMAc & $4.38 \%$ & $17.35 \%$ & 0.09 & & $78.27 \%$ & $5: 95$ \\
\hline
\end{tabular}


Table S2. Results of HTE solvent survey.

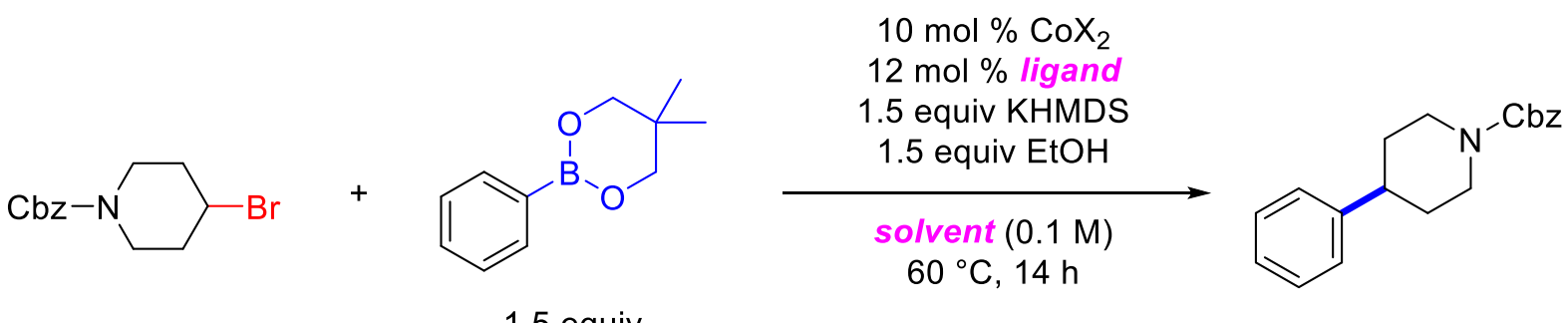

1.5 equiv

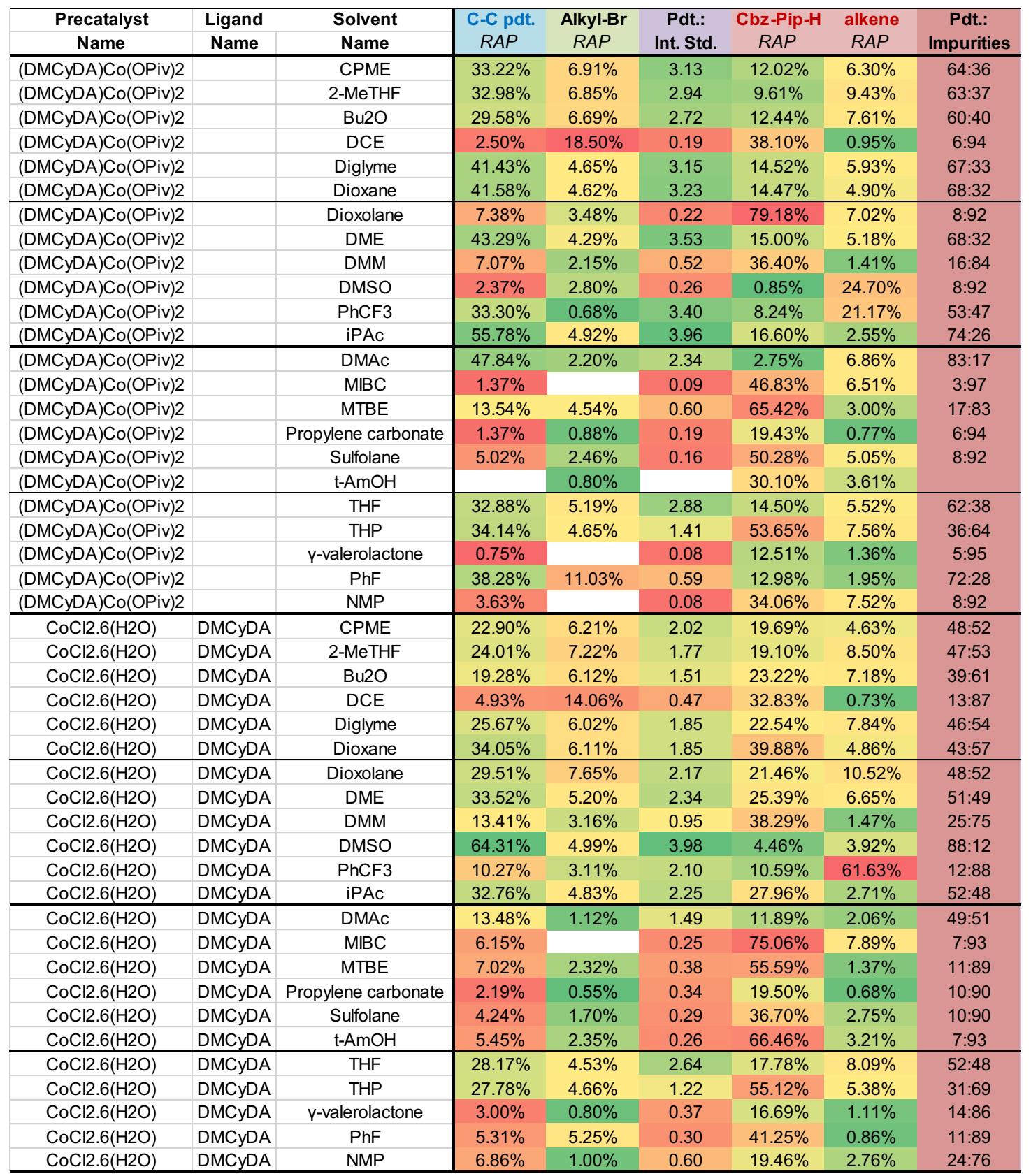




\begin{tabular}{|c|c|c|c|c|c|c|c|c|}
\hline $\begin{array}{l}\text { Precatalyst } \\
\text { Name }\end{array}$ & $\begin{array}{l}\text { Ligand } \\
\text { Name }\end{array}$ & $\begin{array}{c}\text { Solvent } \\
\text { Name }\end{array}$ & $\begin{array}{c}\text { C-C pdt. } \\
R A P\end{array}$ & $\begin{array}{c}\text { Alkyl-Br } \\
R A P\end{array}$ & $\begin{array}{c}\text { Pdt.: } \\
\text { Int. Std. }\end{array}$ & $\begin{array}{c}\text { Cbz-Pip-H } \\
R A P\end{array}$ & $\begin{array}{l}\text { alkene } \\
R A P\end{array}$ & $\begin{array}{c}\text { Pdt.: } \\
\text { Impurities }\end{array}$ \\
\hline (TMEDA)Co(OPiv)2 & & CPME & & $3.69 \%$ & & $40.92 \%$ & $2.12 \%$ & \\
\hline (TMEDA)Co(OPiv)2 & & 2-MeTHF & $12.98 \%$ & $11.38 \%$ & 1.25 & $15.81 \%$ & $7.81 \%$ & $35: 65$ \\
\hline (TMEDA)Co(OPiv)2 & & $\mathrm{Bu} 2 \mathrm{O}$ & $0.79 \%$ & $1.53 \%$ & 0.10 & $26.76 \%$ & $0.99 \%$ & 3:97 \\
\hline (TMEDA)Co(OPiv)2 & & DCE & & $1.54 \%$ & & $28.32 \%$ & $1.24 \%$ & \\
\hline (TMEDA)Co(OPiv)2 & & Diglyme & $32.15 \%$ & $3.07 \%$ & 3.28 & $15.82 \%$ & $2.28 \%$ & $64: 36$ \\
\hline (TMEDA)Co(OPiv)2 & & Dioxane & $14.48 \%$ & $7.32 \%$ & 1.48 & $20.64 \%$ & $7.04 \%$ & $34: 66$ \\
\hline (TMEDA)Co(OPiv)2 & & Dioxolane & $11.12 \%$ & $8.84 \%$ & 1.25 & $16.88 \%$ & $11.24 \%$ & $28: 72$ \\
\hline (TMEDA)Co(OPiv)2 & & DME & $27.05 \%$ & $4.42 \%$ & 2.69 & $17.31 \%$ & $2.91 \%$ & $57: 43$ \\
\hline (TMEDA)Co(OPiv)2 & & DMM & & & & $27.16 \%$ & $2.32 \%$ & \\
\hline (TMEDA)Co(OPiv)2 & & DMSO & $21.61 \%$ & $4.72 \%$ & 0.82 & $5.34 \%$ & $6.13 \%$ & $65: 35$ \\
\hline (TMEDA)Co(OPiv)2 & & PhCF3 & $0.89 \%$ & $1.79 \%$ & 0.21 & $19.39 \%$ & $48.84 \%$ & $1: 99$ \\
\hline (TMEDA)Co(OPiv)2 & & iPAc & $27.54 \%$ & $4.67 \%$ & 2.19 & $24.59 \%$ & $1.68 \%$ & $51: 49$ \\
\hline (TMEDA)Co(OPiv)2 & & DMAC & $14.82 \%$ & $2.84 \%$ & 1.12 & $6.70 \%$ & $31.10 \%$ & $28: 72$ \\
\hline (TMEDA)Co(OPiv)2 & & MIBC & $4.56 \%$ & & 0.63 & $26.94 \%$ & $1.44 \%$ & $14: 86$ \\
\hline (TMEDA)Co(OPiv)2 & & MTBE & & $1.16 \%$ & & $40.86 \%$ & $2.22 \%$ & \\
\hline (TMEDA)Co(OPiv)2 & & Propylene carbonate & $0.84 \%$ & $0.57 \%$ & 0.14 & $17.66 \%$ & $4.60 \%$ & 4:96 \\
\hline (TMEDA)Co(OPiv)2 & & Sulfolane & & & & $23.04 \%$ & $16.86 \%$ & \\
\hline (TMEDA)Co(OPiv)2 & & $\mathrm{t}-\mathrm{AmOH}$ & & & & $27.26 \%$ & $1.16 \%$ & \\
\hline (TMEDA)Co(OPiv)2 & & THF & $26.07 \%$ & $4.27 \%$ & 3.21 & $13.49 \%$ & $3.84 \%$ & $60: 40$ \\
\hline (TMEDA)Co(OPiv)2 & & THP & $10.30 \%$ & $6.25 \%$ & 0.48 & $56.74 \%$ & $4.59 \%$ & $14: 86$ \\
\hline (TMEDA)Co(OPiv)2 & & $\mathrm{Y}$-valerolactone & & & & $11.81 \%$ & $9.81 \%$ & \\
\hline (TMEDA)Co(OPiv)2 & & $\mathrm{PhF}$ & & $1.74 \%$ & & $30.36 \%$ & $2.07 \%$ & \\
\hline (TMEDA)Co(OPiv)2 & & NMP & & & & $19.15 \%$ & $38.58 \%$ & \\
\hline $\mathrm{CoCl} 2.6(\mathrm{H} 2 \mathrm{O})$ & TMEDA & CPME & & & & $25.17 \%$ & $3.20 \%$ & \\
\hline $\mathrm{CoCl} 2.6(\mathrm{H} 2 \mathrm{O})$ & TMEDA & 2-MeTHF & & $7.69 \%$ & & $34.22 \%$ & $8.70 \%$ & \\
\hline $\mathrm{CoCl} 2.6(\mathrm{H} 2 \mathrm{O})$ & TMEDA & Bu2O & & & & $32.48 \%$ & $5.01 \%$ & \\
\hline $\mathrm{CoCl} 2.6(\mathrm{H} 2 \mathrm{O})$ & TMEDA & DCE & & $4.87 \%$ & & $36.18 \%$ & $7.88 \%$ & \\
\hline $\mathrm{CoCl} 2.6(\mathrm{H} 2 \mathrm{O})$ & TMEDA & Diglyme & & $2.12 \%$ & & $31.94 \%$ & $25.88 \%$ & \\
\hline $\mathrm{CoCl} 2.6(\mathrm{H} 2 \mathrm{O})$ & TMEDA & Dioxane & & $5.32 \%$ & & $38.57 \%$ & $5.12 \%$ & \\
\hline $\mathrm{CoCl} 2.6(\mathrm{H} 2 \mathrm{O})$ & TMEDA & Dioxolane & & $7.86 \%$ & & $35.14 \%$ & $8.38 \%$ & \\
\hline $\mathrm{CoCl} 2.6(\mathrm{H} 2 \mathrm{O})$ & TMEDA & DME & & $2.62 \%$ & & $39.93 \%$ & $2.72 \%$ & \\
\hline $\mathrm{CoCl} 2.6(\mathrm{H} 2 \mathrm{O})$ & TMEDA & DMM & & & & $19.93 \%$ & $0.47 \%$ & \\
\hline $\mathrm{CoCl} 2.6(\mathrm{H} 2 \mathrm{O})$ & TMEDA & DMSO & $3.25 \%$ & $1.75 \%$ & 0.15 & $14.17 \%$ & $10.24 \%$ & $12: 88$ \\
\hline $\mathrm{CoCl} 2.6(\mathrm{H} 2 \mathrm{O})$ & TMEDA & PhCF3 & $0.65 \%$ & $1.56 \%$ & 0.15 & $22.04 \%$ & $52.47 \%$ & 1:99 \\
\hline $\mathrm{CoCl} 2.6(\mathrm{H} 2 \mathrm{O})$ & TMEDA & iPAc & & $1.98 \%$ & & $47.84 \%$ & $11.86 \%$ & \\
\hline $\mathrm{CoCl} 2.6(\mathrm{H} 2 \mathrm{O})$ & TMEDA & DMAc & & & & $19.48 \%$ & $25.72 \%$ & \\
\hline $\mathrm{CoCl} 2.6(\mathrm{H} 2 \mathrm{O})$ & TMEDA & MIBC & $9.20 \%$ & & 0.60 & $52.79 \%$ & $3.86 \%$ & $14: 86$ \\
\hline $\mathrm{CoCl} 2.6(\mathrm{H} 2 \mathrm{O})$ & TMEDA & MTBE & & & & $34.99 \%$ & $2.66 \%$ & \\
\hline $\mathrm{CoCl} 2.6(\mathrm{H} 2 \mathrm{O})$ & TMEDA & Propylene carbonate & & & & $15.68 \%$ & $1.46 \%$ & \\
\hline $\mathrm{CoCl} 2.6(\mathrm{H} 2 \mathrm{O})$ & TMEDA & Sulfolane & & & & $21.64 \%$ & $7.56 \%$ & \\
\hline $\mathrm{CoCl} 2.6(\mathrm{H} 2 \mathrm{O})$ & TMEDA & $\mathrm{t}-\mathrm{AmOH}$ & & & & $48.76 \%$ & $6.88 \%$ & \\
\hline $\mathrm{CoCl} 2.6(\mathrm{H} 2 \mathrm{O})$ & TMEDA & THF & & $4.50 \%$ & & $34.20 \%$ & $7.15 \%$ & \\
\hline $\mathrm{CoCl} 2.6(\mathrm{H} 2 \mathrm{O})$ & TMEDA & THP & & $3.86 \%$ & & $52.70 \%$ & $3.33 \%$ & \\
\hline $\mathrm{CoCl} 2.6(\mathrm{H} 2 \mathrm{O})$ & TMEDA & Y-valerolactone & & & & $11.86 \%$ & $6.23 \%$ & \\
\hline $\mathrm{CoCl} 2.6(\mathrm{H} 2 \mathrm{O})$ & TMEDA & $\mathrm{PhF}$ & & & & $35.14 \%$ & $2.10 \%$ & \\
\hline $\mathrm{CoCl} 2.6(\mathrm{H} 2 \mathrm{O})$ & TMEDA & NMP & & & & $10.73 \%$ & $12.98 \%$ & \\
\hline
\end{tabular}


Table S3. Results of HTE ligand and solvent survey.

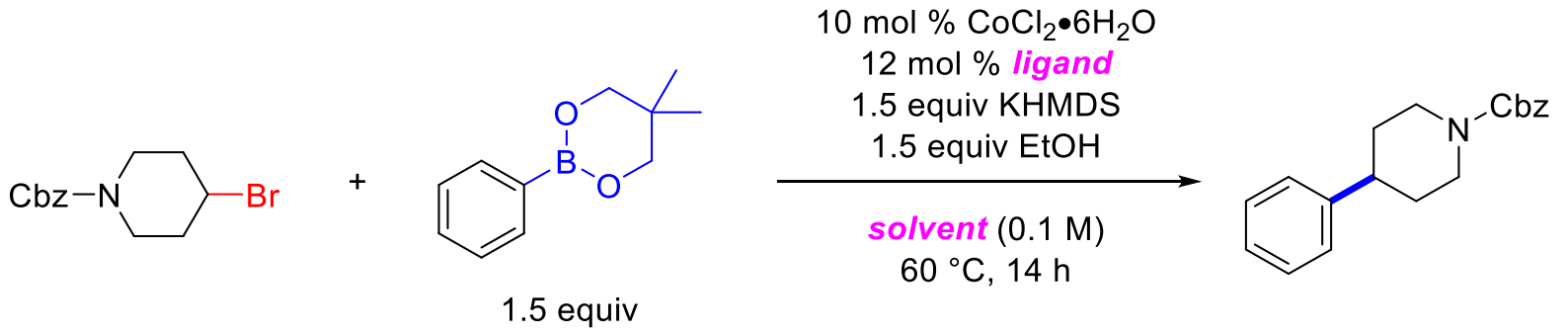

\begin{tabular}{|c|c|c|c|c|c|c|c|}
\hline Ligand & Solvent & C-C pdt. & Alkyl-Br & Pdt.: & Cbz-Pip-H & alkene & Pdt.: \\
\hline Name & Name & $R A P$ & RAP & Int. Std. & $R A P$ & RAP & Impurities \\
\hline DMEDA & THF & $5.61 \%$ & $5.99 \%$ & 0.56 & $36.69 \%$ & $7.32 \%$ & $11: 89$ \\
\hline DMEDA & PhF & & $0.82 \%$ & & $37.20 \%$ & $1.28 \%$ & \\
\hline DMEDA & DMSO & & $6.58 \%$ & & $62.56 \%$ & $13.04 \%$ & \\
\hline DMEDA & 90:10 PhF:THF & $1.10 \%$ & $4.32 \%$ & 0.12 & $45.52 \%$ & $1.18 \%$ & $2: 98$ \\
\hline DMEDA & 80:20 PhF:THF & $3.42 \%$ & $7.30 \%$ & 0.35 & $45.65 \%$ & $3.18 \%$ & $7: 93$ \\
\hline DMEDA & 50:50 PhF:THF & $4.67 \%$ & $8.40 \%$ & 0.44 & $41.47 \%$ & $5.58 \%$ & 9:91 \\
\hline TsDPEN-SS & THF & $8.53 \%$ & $4.86 \%$ & 0.70 & $42.62 \%$ & $10.96 \%$ & $14: 86$ \\
\hline TsDPEN-SS & PhF & $2.45 \%$ & $4.10 \%$ & 0.24 & $50.63 \%$ & $5.75 \%$ & $4: 96$ \\
\hline TsDPEN-SS & DMSO & $34.37 \%$ & $15.84 \%$ & 1.42 & $31.68 \%$ & $7.01 \%$ & $47: 53$ \\
\hline TsDPEN-SS & 90:10 PhF:THF & $4.78 \%$ & $7.51 \%$ & 0.37 & $60.85 \%$ & $7.39 \%$ & $7: 93$ \\
\hline TsDPEN-SS & 80:20 PhF:THF & $6.54 \%$ & $8.98 \%$ & 0.44 & $65.88 \%$ & $2.78 \%$ & 9:91 \\
\hline TsDPEN-SS & 50:50 PhF:THF & $7.29 \%$ & $6.98 \%$ & 0.55 & $49.78 \%$ & $9.92 \%$ & 11:89 \\
\hline TMEDA & THF & $8.58 \%$ & $4.95 \%$ & 0.89 & $29.00 \%$ & $6.80 \%$ & $19: 81$ \\
\hline TMEDA & PhF & & & & $35.32 \%$ & $1.31 \%$ & \\
\hline TMEDA & DMSO & $13.58 \%$ & $10.05 \%$ & 0.28 & $44.61 \%$ & $11.99 \%$ & $19: 81$ \\
\hline TMEDA & 90:10 PhF:THF & & $1.97 \%$ & & $36.89 \%$ & $6.61 \%$ & \\
\hline TMEDA & 80:20 PhF:THF & $7.34 \%$ & $6.40 \%$ & 0.83 & $37.51 \%$ & $2.77 \%$ & $15: 85$ \\
\hline TMEDA & 50:50 PhF:THF & $9.72 \%$ & $6.54 \%$ & 1.11 & $29.58 \%$ & $5.55 \%$ & $22: 78$ \\
\hline BINAM-R & THF & $1.95 \%$ & $2.21 \%$ & 0.20 & $42.08 \%$ & $2.62 \%$ & $4: 96$ \\
\hline BINAM-R & PhF & & & & $37.08 \%$ & $2.02 \%$ & \\
\hline BINAM-R & DMSO & $14.08 \%$ & $11.02 \%$ & 0.49 & $44.12 \%$ & $9.44 \%$ & $21: 79$ \\
\hline BINAM-R & 90:10 PhF:THF & & $1.23 \%$ & & $42.62 \%$ & $8.88 \%$ & \\
\hline BINAM-R & 80:20 PhF:THF & & $1.76 \%$ & & $44.49 \%$ & $13.43 \%$ & \\
\hline BINAM-R & 50:50 PhF:THF & $1.21 \%$ & $4.07 \%$ & 0.13 & $44.60 \%$ & $1.46 \%$ & $3: 97$ \\
\hline TMPDA & THF & $7.15 \%$ & $5.66 \%$ & 0.75 & $35.46 \%$ & $6.73 \%$ & $14: 86$ \\
\hline TMPDA & PhF & & & & $37.56 \%$ & $1.38 \%$ & \\
\hline TMPDA & DMSO & & $7.79 \%$ & & $58.32 \%$ & $12.46 \%$ & \\
\hline TMPDA & 90:10 PhF:THF & $1.27 \%$ & $4.14 \%$ & 0.14 & $44.24 \%$ & $1.12 \%$ & $3: 97$ \\
\hline TMPDA & 80:20 PhF:THF & $3.19 \%$ & $5.52 \%$ & 0.28 & $40.79 \%$ & $6.46 \%$ & $6: 94$ \\
\hline TMPDA & 50:50 PhF:THF & $5.08 \%$ & $7.25 \%$ & 0.52 & $39.13 \%$ & $4.97 \%$ & $10: 90$ \\
\hline DMDPEN-SS & THF & $21.62 \%$ & $8.18 \%$ & 1.94 & $21.32 \%$ & $15.38 \%$ & $37: 63$ \\
\hline DMDPEN-SS & PhF & $22.97 \%$ & $17.52 \%$ & 2.64 & $26.30 \%$ & $3.63 \%$ & $43: 57$ \\
\hline DMDPEN-SS & DMSO & $31.11 \%$ & $9.81 \%$ & 1.69 & $28.35 \%$ & $4.05 \%$ & $49: 51$ \\
\hline DMDPEN-SS & 90:10 PhF:THF & $26.04 \%$ & $19.80 \%$ & 2.09 & $36.42 \%$ & $6.88 \%$ & $38: 62$ \\
\hline DMDPEN-SS & 80:20 PhF:THF & $22.02 \%$ & $14.62 \%$ & 2.14 & $30.43 \%$ & $6.90 \%$ & $37: 63$ \\
\hline DMDPEN-SS & 50:50 PhF:THF & $23.28 \%$ & $11.18 \%$ & 2.30 & $25.84 \%$ & $10.17 \%$ & 39:61 \\
\hline TMBDA & THF & $1.96 \%$ & $3.15 \%$ & 0.18 & $40.71 \%$ & $4.08 \%$ & $4: 96$ \\
\hline TMBDA & PhF & & & & $36.28 \%$ & $1.74 \%$ & \\
\hline TMBDA & DMSO & & & & $17.22 \%$ & $0.45 \%$ & \\
\hline TMBDA & 90:10 PhF:THF & & $1.77 \%$ & & $41.18 \%$ & $9.35 \%$ & \\
\hline TMBDA & 80:20 PhF:THF & & $4.92 \%$ & & $45.39 \%$ & $1.58 \%$ & \\
\hline TMBDA & 50:50 PhF:THF & & $3.20 \%$ & & $46.51 \%$ & $2.70 \%$ & \\
\hline Aminolndanol-RS & THF & & & & $55.79 \%$ & $1.96 \%$ & \\
\hline Aminolndanol-RS & PhF & & $2.45 \%$ & & $51.59 \%$ & $6.78 \%$ & \\
\hline Aminolndanol-RS & DMSO & & $6.82 \%$ & & $37.75 \%$ & $7.29 \%$ & \\
\hline Aminolndanol-RS & 90:10 PhF:THF & & $2.04 \%$ & & $58.28 \%$ & $8.66 \%$ & \\
\hline Aminolndanol-RS & 80:20 PhF:THF & & $1.98 \%$ & & $57.58 \%$ & $9.82 \%$ & \\
\hline Aminolndanol-RS & 50:50 PhF:THF & & & & $55.95 \%$ & $11.72 \%$ & \\
\hline
\end{tabular}




\begin{tabular}{|c|c|c|c|c|c|c|c|}
\hline $\begin{array}{l}\text { Ligand } \\
\text { Name }\end{array}$ & $\begin{array}{l}\text { Solvent } \\
\text { Name }\end{array}$ & $\begin{array}{c}\text { C-C pdt. } \\
R A P\end{array}$ & $\begin{array}{c}\text { Alkyl-Br } \\
R A P\end{array}$ & Pdt:: & $\begin{array}{c}\text { Cbz-Pip-H } \\
R A P\end{array}$ & alkene & Pdt.: \\
\hline DMCyDA & THF & $21.19 \%$ & $5.56 \%$ & 2.19 & $22.47 \%$ & $11.19 \%$ & $39 \cdot 61$ \\
\hline DMCyDA & $\mathrm{PhF}$ & $21.18 \%$ & $13.44 \%$ & 257 & $28.20 \%$ & $243 \%$ & $41: 59$ \\
\hline DMCyDA & DMSO & $46.05 \%$ & $11.65 \%$ & 2.55 & $19.91 \%$ & $9.23 \%$ & $61: 39$ \\
\hline DMCyDA & 90:10 PhF:THF & $22.94 \%$ & $13.07 \%$ & 2.30 & $32.08 \%$ & $4.11 \%$ & $39: 61$ \\
\hline DMCyDA & 80:20 PhF:THF & $22.19 \%$ & $11.63 \%$ & 2.22 & $30.33 \%$ & $5.15 \%$ & $38: 62$ \\
\hline DMCyDA & 50:50 PhF:THF & $21.70 \%$ & $8.86 \%$ & 2.12 & $26.26 \%$ & $7.61 \%$ & $39: 61$ \\
\hline Bipyrrolidine-R & THF & $25.84 \%$ & $3.63 \%$ & 1.97 & $26.46 \%$ & $15.58 \%$ & $38: 62$ \\
\hline Bipyrrolidine-R & PhF & $17.75 \%$ & $11.93 \%$ & 1.91 & $33.03 \%$ & $2.67 \%$ & $33: 67$ \\
\hline Bipyrrolidine-R & DMSO & $47.88 \%$ & $9.55 \%$ & 2.57 & $19.40 \%$ & $9.15 \%$ & $63: 37$ \\
\hline Bipyrrolidine-R & 90:10 PhF:THF & $20.67 \%$ & $12.43 \%$ & 1.82 & $40.19 \%$ & $4.28 \%$ & $32: 68$ \\
\hline Bipyrrolidine-R & 80:20 PhF:THF & $20.66 \%$ & $11.43 \%$ & 1.80 & $37.66 \%$ & $5.56 \%$ & $32: 68$ \\
\hline Bipyrrolidine-R & 50:50 PhF:THF & $22.80 \%$ & $9.18 \%$ & 1.94 & $30.71 \%$ & $8.93 \%$ & $37: 63$ \\
\hline T-DACH-SS & THF & $11.22 \%$ & $9.18 \%$ & 1.01 & $28.08 \%$ & $14.27 \%$ & $21: 79$ \\
\hline T-DACH-SS & PhF & $13.04 \%$ & $13.77 \%$ & 1.71 & $33.11 \%$ & $1.51 \%$ & $27: 73$ \\
\hline T-DACH-SS & DMSO & $26.38 \%$ & $14.09 \%$ & 0.86 & $44.73 \%$ & $6.29 \%$ & $34: 66$ \\
\hline T-DACH-SS & 90:10 PhF:THF & $13.55 \%$ & $15.50 \%$ & 1.36 & $37.73 \%$ & $5.75 \%$ & $24: 76$ \\
\hline T-DACH-SS & 80:20 PhF:THF & $12.89 \%$ & $13.82 \%$ & 1.30 & $38.80 \%$ & $6.79 \%$ & $22: 78$ \\
\hline T-DACH-SS & 50:50 PhF:THF & $12.22 \%$ & $14.22 \%$ & 1.07 & $34.27 \%$ & $11.62 \%$ & $21: 79$ \\
\hline Ephedrine-RS HCl & THF & $5.08 \%$ & & 0.48 & $44.50 \%$ & $4.27 \%$ & $9: 91$ \\
\hline Ephedrine-RS HCl & PhF & $1.64 \%$ & $3.36 \%$ & 0.19 & $47.04 \%$ & $1.17 \%$ & $3: 97$ \\
\hline Ephedrine-RS HCl & DMSO & & & & $75.28 \%$ & $13.14 \%$ & \\
\hline Ephedrine-RS $\mathrm{HCl}$ & 90:10 PhF:THF & $5.94 \%$ & $7.21 \%$ & 0.63 & $46.26 \%$ & $1.72 \%$ & $11: 89$ \\
\hline Ephedrine-RS HCl & 80:20 PhF:THF & $2.07 \%$ & $4.08 \%$ & 0.18 & $57.56 \%$ & $1.64 \%$ & $3: 97$ \\
\hline Ephedrine-RS HCl & 50:50 PhF:THF & $2.44 \%$ & $4.38 \%$ & 0.25 & $47.75 \%$ & $2.70 \%$ & $5: 95$ \\
\hline TMCyDA-RR & THF & $13.67 \%$ & $1.65 \%$ & 1.45 & $27.61 \%$ & $6.56 \%$ & $29: 71$ \\
\hline TMCyDA-RR & PhF & & & & $35.32 \%$ & $1.34 \%$ & \\
\hline TMCyDA-RR & DMSO & & $7.75 \%$ & & $58.79 \%$ & $12.52 \%$ & \\
\hline TMCyDA-RR & 90:10 PhF:THF & $4.05 \%$ & $1.58 \%$ & 0.51 & $37.27 \%$ & $8.69 \%$ & $8: 92$ \\
\hline TMCyDA-RR & 80:20 PhF:THF & $12.66 \%$ & $4.82 \%$ & 1.30 & $37.76 \%$ & $2.52 \%$ & $24: 76$ \\
\hline TMCyDA-RR & 50:50 PhF:THF & $14.16 \%$ & $4.97 \%$ & 1.45 & $31.78 \%$ & $4.68 \%$ & $28: 72$ \\
\hline PR-L & THF & & $3.48 \%$ & & $56.49 \%$ & $11.91 \%$ & \\
\hline PR-L & PhF & & & & $33.16 \%$ & $1.54 \%$ & \\
\hline PR-L & DMSO & $10.17 \%$ & $7.24 \%$ & 0.21 & $46.16 \%$ & $11.93 \%$ & $15: 85$ \\
\hline PR-L & 90:10 PhF:THF & & & & $44.66 \%$ & $7.90 \%$ & \\
\hline PR-L & 80:20 PhF:THF & & & & $53.47 \%$ & $10.95 \%$ & \\
\hline PR-L & 50:50 PhF:THF & & $2.54 \%$ & & $61.07 \%$ & $3.47 \%$ & \\
\hline DMDtHexCyDA HCl & THF & & & & $47.01 \%$ & $8.43 \%$ & \\
\hline DMDtHexCyDA HCl & PhF & & & & $44.31 \%$ & $2.50 \%$ & \\
\hline DMDtHexCyDA HCl & DMSO & & & & $75.41 \%$ & $10.47 \%$ & \\
\hline DMDtHexCyDA HCl & 90:10 PhF:THF & & & & $56.26 \%$ & $4.10 \%$ & \\
\hline DMDtHexCyDA HCl & 80:20 PhF:THF & & $11.82 \%$ & & $51.04 \%$ & $4.76 \%$ & \\
\hline DMDtHexCyDA HCl & 50:50 PhF:THF & & $3.86 \%$ & & $51.82 \%$ & $2.05 \%$ & \\
\hline PhNCH2-Pyrrolidine-S & THF & $3.91 \%$ & & 0.28 & $57.05 \%$ & $7.47 \%$ & $6: 94$ \\
\hline PhNCH2-Pyrrolidine-S & PhF & & & & $43.46 \%$ & $1.36 \%$ & \\
\hline PhNCH2-Pyrrolidine-S & DMSO & & $43.21 \%$ & & & & \\
\hline PhNCH2-Pyrrolidine-S & 90:10 PhF:THF & $2.97 \%$ & $2.85 \%$ & 0.25 & $61.29 \%$ & $2.14 \%$ & $4: 96$ \\
\hline PhNCH2-Pyrrolidine-S & 80:20 PhF:THF & $4.14 \%$ & $3.60 \%$ & 0.34 & $58.93 \%$ & $3.23 \%$ & $6: 94$ \\
\hline PhNCH2-Pyrrolidine-S & 50:50 PhF:THF & $3.53 \%$ & $3.12 \%$ & 0.25 & $58.64 \%$ & $5.38 \%$ & $5: 95$ \\
\hline
\end{tabular}

\section{Reaction Optimization}




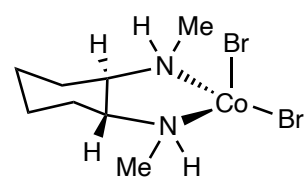

$(R, R$-DMCyDA)CoBr 2

$\left(\boldsymbol{R}, \boldsymbol{R}\right.$-DMCyDA)CoBr 2 . In an $\mathrm{N}_{2}$-filled glovebox, a $20 \mathrm{~mL}$ screw-capped vial equipped with a magnetic stir bar was charged with $\mathrm{CoBr}_{2}(437 \mathrm{mg}, 2 \mathrm{mmol}$, green solid) and THF (5 mL). To this blue solution, a solution of $(R, R)-(-)-N, N^{\prime}-$ Dimethyl-1,2-cyclohexanediamine (313 $\mathrm{mg}, 2.2$ $\mathrm{mmol})$ in THF (5 mL) was added slowly. The initially pink suspension eventually turned into a blue solution. After stirring for 2 hours at room temperature, the reaction was concentrated under reduced pressure. Pentane was added, and subsequently removed under reduced pressure. This process was repeated until all THF was completely removed from the vial (the pentane should appear colorless, this usually happened after two or three repeats of the pentane addition/removal cycle). Filtering the blue pentane suspension on a glass frit gave a blue solid. Additional washing with pentane and drying under reduced pressure gave $768 \mathrm{mg}$ ( $97 \%$ yield) of blue solid that was directly used in catalytic reactions without further purification.

Anal. Calcd. for $\mathrm{C}_{8} \mathrm{H}_{18} \mathrm{Br}_{2} \mathrm{CoN}_{2}$ : C, 26.62; H, 5.03; N, 7.76. Found: C, 26.85; H, 5.08; N, 7.63.

Magnetic susceptibility (Guoy balance, $296 \mathrm{~K}$ ): $\mu_{\mathrm{eff}}=3.8 \mu_{\mathrm{B}}$. HRMS (ESI) $\mathrm{m} / \mathrm{z}$ : [M+DMA-Br] ${ }^{+}$ Calcd for $\mathrm{C}_{12} \mathrm{H}_{27} \mathrm{BrCoN}_{3} \mathrm{O}^{+}$367.0664; Found 367.0667.

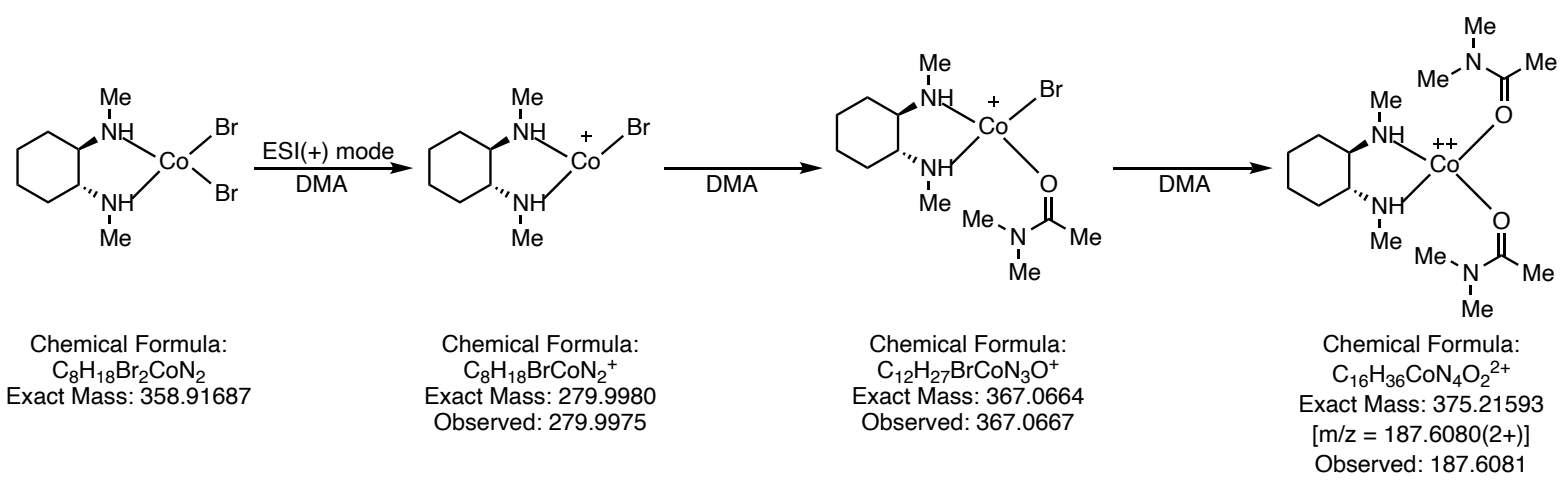

Figure S2. HRMS analysis of $(R, R$-DMCyDA $) \mathrm{CoBr}_{2}$ in $N, N$-dimethylacetamide. 


\section{General procedure for optimization experiments}

Optimization experiments were run on a $0.25 \mathrm{mmol}$ scale. In an $\mathrm{N}_{2}$-filled glovebox, a $20 \mathrm{~mL}$ screw-capped vial equipped with a magnetic stir bar was charged with base, cobalt source, and solvent. Then, the aryl boron reagent, 1,3,5-Tri-tert-butylbenzene (internal standard), and the alkyl bromide were added either neat or in solution, depending on solubility. The vial was capped, and the reaction was allowed to stir for the time and at the temperature (on a hotplate) indicated in the table. A $10 \mu \mathrm{L}$ aliquot was removed from each reaction that was diluted to $1 \mathrm{~mL}$ with a 4:1 mixture of acetonitrile:water. A $400 \mu \mathrm{L}$ portion of this solution was passed through a $0.7 \mu \mathrm{m}$ filter before being analyzed directly by UPLC-MS.

Table S4. Previously reported Co catalysts and Co salts in the coupling of 4-bromo-N-Cbzpiperidine with $\mathrm{PhB}(\mathrm{neo})$.

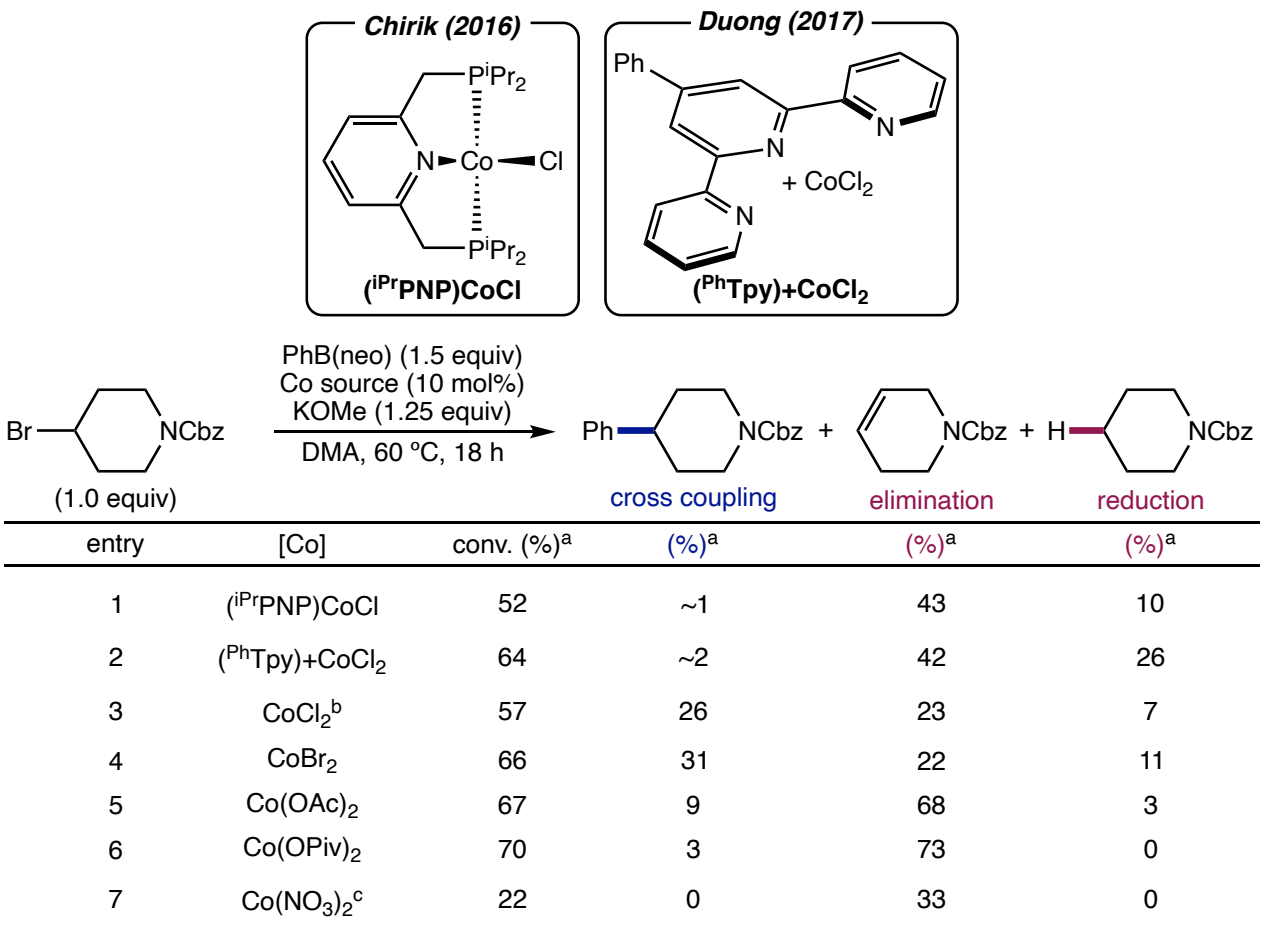

aYield and conversion measured by UPLC using 1,3,5-tri-tert-butylbenzene as an internal standard. b99.99\%. Chexahydrate salt. 
Table S5. Initial ICP-MS analysis of $\mathrm{PhB}($ neo) and Co salts.

\begin{tabular}{|c|c|c|c|c|c|c|c|c|c|c|c|c|c|c|}
\hline & \multicolumn{14}{|c|}{ Concentration (ppm w/w) } \\
\hline & Al & $\mathrm{Cr}$ & $\mathrm{Fe}$ & Mn & Co & $\mathbf{N i}$ & $\mathrm{Cu}$ & $\mathrm{Zn}$ & As & Pd & Sn & $\mathrm{Pb}$ & $\mathbf{B i}$ & B \\
\hline PhB(neo) & $<10$ & $<10$ & 0.3 & $<10$ & $<10$ & $<10$ & $<10$ & $<10$ & $<10$ & $<10$ & $<10$ & $<10$ & $<10$ & 50512 \\
\hline $\begin{array}{c}\text { Co(OPiv) }{ }_{2} \\
\text { (homemade) }\end{array}$ & $<10$ & $<10$ & 9.7 & $<10$ & 211779 & $<10$ & $<10$ & $<10$ & 116 & $<10$ & $<10$ & $<10$ & $<10$ & \\
\hline $\begin{array}{c}\mathrm{CoCl}_{2} \text { (Alfa } \\
\text { Aesar, 99.7\%) } \\
\text { Sample } 1 \\
\end{array}$ & 41 & $<10$ & 13 & 35 & 414231 & 132 & $<10$ & $<10$ & 230 & $<10$ & $<10$ & $<10$ & $<10$ & \\
\hline $\begin{array}{c}\mathrm{CoCl}_{2} \text { (Alfa } \\
\text { Aesar, 99.7\%) } \\
\text { Sample } 2\end{array}$ & 31 & $<10$ & 20 & 37 & 450036 & 128 & $<10$ & $<10$ & 252 & $<10$ & $<10$ & $<10$ & $<10$ & \\
\hline
\end{tabular}

Table S6. Diamine ligands in the Co-catalyzed Suzuki coupling of 4-bromo-N-Cbz-piperidine with $\mathrm{PhB}($ neo).

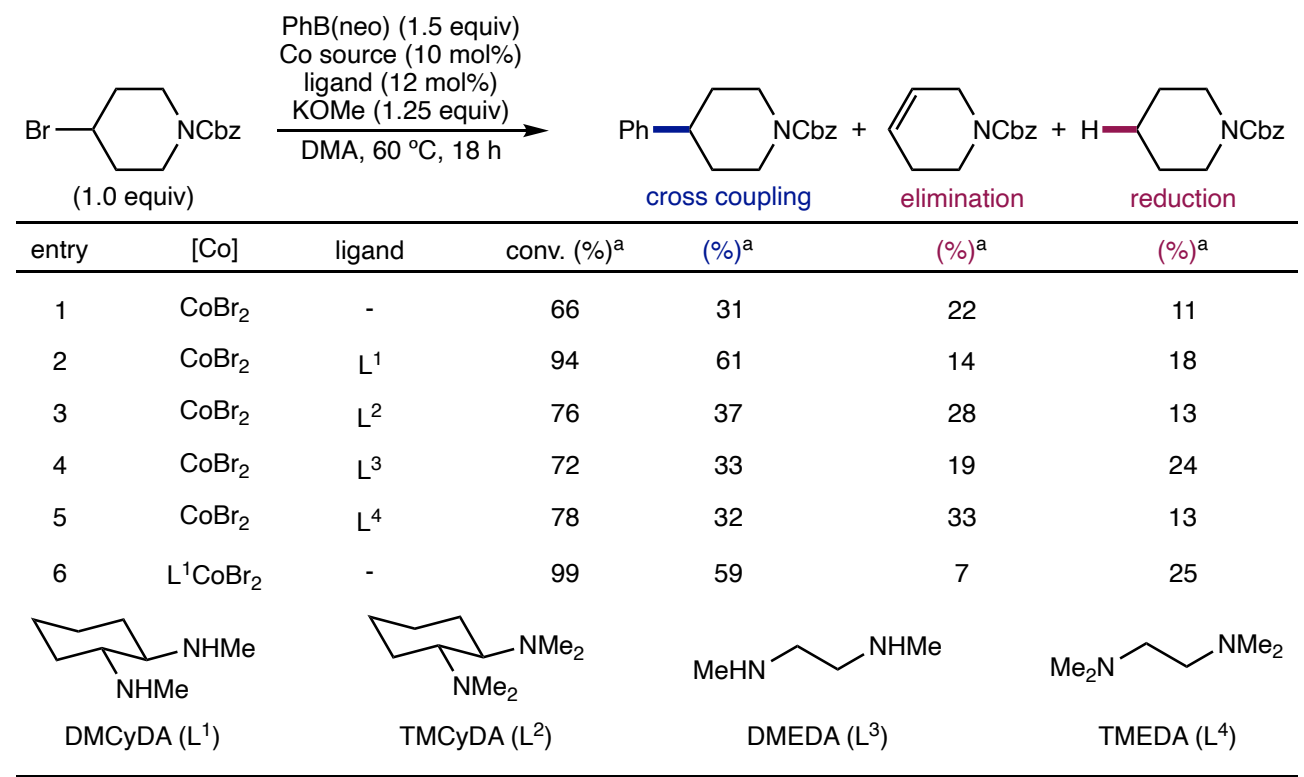

For $L^{1}$ and $L^{2}$, racemic trans diastereomer was used. For the isolated precatalyst, enantiopure ligand was used. aYield and conversion measured by UPLC using 1,3,5-tri-tert-butylbenzene as an internal standard. 
Table S7. ICP-MS analysis of KOMe and Co precatalysts.

\begin{tabular}{|c|c|c|c|c|c|c|}
\cline { 2 - 7 } & \multicolumn{6}{|c|}{ Concentration (ppm w/w) } \\
\hline KOMe (Strem) & 3 & 3 & & & & \\
\hline KOMe (Aldrich) & 7 & 3 & & & & \\
\hline DMCyDACo(OPiv)2 & 12 & & 2 & 2 & 7 & 58 \\
\hline DMCyDACoBr2 Sample 1 & 5 & & 9 & 4 & 3 & 86 \\
\hline DMCyDACoBr2 Sample 2 & 0 & & 7 & 3 & 2 & 71 \\
\hline
\end{tabular}

Table S8. Bases used in the coupling of 4-bromo-N-Cbz-piperidine with $\mathrm{PhB}(\mathrm{neo})$.

\begin{tabular}{|c|c|c|c|c|c|}
\hline \multirow{2}{*}{$\begin{array}{r}\mathrm{Br} \\
\text { entry } \\
\end{array}$} & \multicolumn{2}{|c|}{$\underbrace{}_{\mathrm{NCbz}} \begin{array}{c}\mathrm{PhB}(\text { neo })(1.5 \text { equiv) } \\
\mathrm{L}^{1} \mathrm{CoBr}_{2}(10 \mathrm{~mol} \%) \\
\text { base (x equiv) }\end{array}$} & cross coupling & $\overbrace{\text { elimination }}^{\mathrm{NCbz}}$ & \multirow{2}{*}{$\frac{\text { reductio }}{(\%)^{\mathrm{a}}}$} \\
\hline & base $(x)$ & conv. $(\%)^{a}$ & $(\%)^{a}$ & $(\%)^{a}$ & \\
\hline 1 & KOMe (1.25) & 99 & 59 & 7 & 25 \\
\hline 2 & KOMe (1.5) & 99 & 49 & 22 & 24 \\
\hline 3 & KOMe (1.75) & 99 & 47 & 17 & 28 \\
\hline 4 & KOEt (1.25) & 86 & 38 & 34 & 17 \\
\hline 5 & KHMDS/EtOH (1.25) & 99 & 48 & 48 & 8 \\
\hline 6 & $\mathrm{NaOMe}(1.25)$ & 95 & 64 & 11 & 19 \\
\hline $7^{b}$ & KOPh (1.25) & 67 & 0 & 78 & 0 \\
\hline $8^{b}$ & KOTMS (1.25) & 6 & $\sim 1$ & 4 & 3 \\
\hline $9^{b}$ & KOMe sol'n $(1.25)^{c}$ & 45 & 0 & 45 & 1 \\
\hline
\end{tabular}

aYield and conversion measured by UPLC using 1,3,5-tri-tert-butylbenzene as an internal standard.

${ }^{b} 21$ hour reaction time. ${ }^{c}$ Commerically available KOMe solution (25 wt. \%) in methanol. 
Table S9. Solvents used in the coupling of 4-bromo-N-Cbz-piperidine with $\mathrm{PhB}(\mathrm{neo})$.

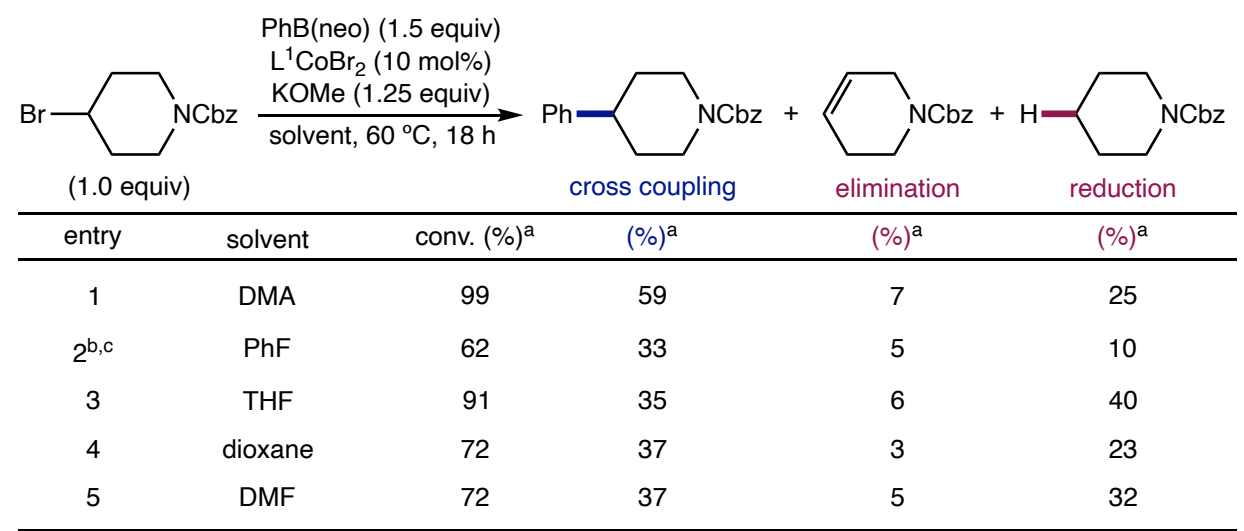

aYield and conversion measured by UPLC using 1,3,5-tri-tert-butylbenzene as an internal standard. b21 hour reaction time. ${ }^{c} \sim 13$ RAP coupling to solvent observed.

Table S10. Catalyst loading and concentration used in the coupling of 4-bromo-N-Cbzpiperidine with $\mathrm{PhB}(\mathrm{neo})$.

\begin{tabular}{|c|c|c|c|c|c|c|}
\hline \multicolumn{2}{|c|}{ Br } & \multicolumn{2}{|c|}{$\begin{array}{l}\mathrm{PhB}(\text { neo })(1.5 \text { equiv) } \\
\mathrm{L}^{1} \mathrm{CoBr}_{2}(\mathrm{x} \text { mol\%) } \\
\stackrel{\mathrm{KOMe}(1.25 \text { equiv })}{\mathrm{DMA}(\mathrm{yM}), 60^{\circ} \mathrm{C}, 18 \mathrm{~h}}\end{array}$} & $\underbrace{\mathrm{NCb}}_{\text {ss coupling }}$ & \multirow{2}{*}{$\frac{\sum_{\text {elimination }}^{\mathrm{NCbz}}}{(\%)^{\mathrm{a}}}$} & \multirow{2}{*}{$\frac{\text { reduction }}{(\%)^{\mathrm{a}}}$} \\
\hline entry & $x(\mathrm{~mol} \%)$ & $y(M)$ & conv. $(\%)^{a}$ & $(\%)^{a}$ & & \\
\hline 1 & 10 & 0.1 & 99 & 59 & 7 & 25 \\
\hline 2 & 1 & 0.1 & 76 & 0 & 87 & 0 \\
\hline 3 & 5 & 0.1 & 89 & 28 & 32 & 29 \\
\hline 4 & 15 & 0.1 & 99 & 69 & 5 & 18 \\
\hline 5 & 20 & 0.1 & 99 & 71 & 3 & 14 \\
\hline 6 & 10 & 0.5 & 91 & 42 & 20 & 12 \\
\hline 7 & 10 & 1.0 & 87 & 34 & 21 & 13 \\
\hline
\end{tabular}

aYield and conversion measured by UPLC using 1,3,5-tri-tert-butylbenzene as an internal standard.

\section{Synthesis of Substrates, Intermediates and Authentic Product Standards \\ General Procedure (A): Condensation of $\mathrm{ArB}(\mathrm{OH})_{2}$ with neopentyl glycol for the synthesis of $\mathrm{ArB}(\mathrm{neo})$ reagents}




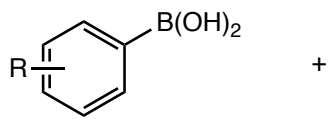

(1 equiv)

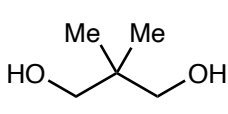

(1.5 equiv)

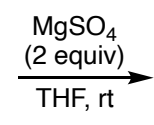

$\overbrace{}^{B(\text { neo })}$

To a $20 \mathrm{~mL}$ screw-capped scintillation vial (or a round bottom flask, depending on scale) equipped with a magnetic stir bar was added aryl boronic acid (1 equiv), neopentyl glycol (1.5 equiv), magnesium sulfate (2 equiv), and THF (0.2 M). The reaction vessel was sealed, and the mixture was allowed to stir at room temperature. After the indicated time, the mixture was filtered over celite and washed with ethyl acetate. The resulting filtrate was concentrated, and the crude material was purified by silica gel column chromatography (hexanes/ethyl acetate as eluent) to afford the corresponding aryl neopentyl glycol boronate ester.

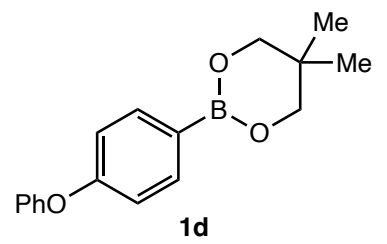

5,5-dimethyl-2-(4-phenoxyphenyl)-1,3,2-dioxaborinane (1d). General procedure A was employed on a $10 \mathrm{mmol}$ scale for $14 \mathrm{~h}$ and yielded $2.32 \mathrm{~g}$ ( $82 \%$ yield) of a white solid identified as 1 d. The ${ }^{1} \mathrm{H}$ NMR data is consistent with literature ${ }^{7}$ reported data. ${ }^{1} \mathrm{H}$ NMR $(400 \mathrm{MHz}$, chloroform-d, $\left.23^{\circ} \mathrm{C}\right): \delta 7.81-7.73(\mathrm{~m}, 2 \mathrm{H}), 7.39-7.29(\mathrm{~m}, 2 \mathrm{H}), 7.16-7.06(\mathrm{~m}, 1 \mathrm{H}), 7.06-$ $6.97(\mathrm{~m}, 2 \mathrm{H}), 7.01-6.93(\mathrm{~m}, 2 \mathrm{H}), 3.76(\mathrm{~s}, 4 \mathrm{H}), 1.03(\mathrm{~s}, 6 \mathrm{H})$.<smiles>FC(F)(F)c1ccc(B2OC[N+]([Na])CO2)cc1</smiles>

5,5-dimethyl-2-(4-(trifluoromethyl)phenyl)-1,3,2-dioxaborinane (1f). General procedure A was employed on a $3 \mathrm{mmol}$ scale for $21 \mathrm{~h}$ and yielded $285 \mathrm{mg}$ (37\% yield) of a white solid identified as 1f. The ${ }^{1} \mathrm{H}$ NMR data is consistent with literature ${ }^{7}$ reported data. ${ }^{1} \mathbf{H}$ NMR (500 
$\mathrm{MHz}$, chloroform-d, $\left.23^{\circ} \mathrm{C}\right): \delta 7.90(\mathrm{~d}, J=7.8 \mathrm{~Hz}, 2 \mathrm{H}), 7.59(\mathrm{~d}, J=7.8 \mathrm{~Hz}, 2 \mathrm{H}), 3.79(\mathrm{~s}, 4 \mathrm{H})$, $1.03(\mathrm{~s}, 6 \mathrm{H})$.

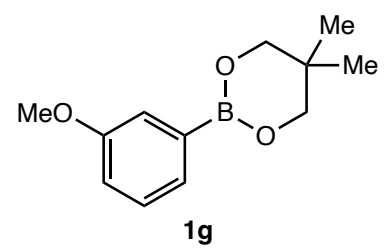

2-(3-methoxyphenyl)-5,5-dimethyl-1,3,2-dioxaborinane (1g). General procedure A was employed on a $3 \mathrm{mmol}$ scale for $48 \mathrm{~h}$ and yielded $387 \mathrm{mg}$ ( $59 \%$ yield) of a white solid identified as $\mathbf{1 g}$. The ${ }^{1} \mathrm{H}$ NMR data is consistent with literature ${ }^{8}$ reported data. ${ }^{1} \mathbf{H}$ NMR $(500 \mathrm{MHz}$, chloroform-d, $\left.23^{\circ} \mathrm{C}\right): \delta 7.42-7.37(\mathrm{~m}, 1 \mathrm{H}), 7.34(\mathrm{~d}, \mathrm{~J}=2.9 \mathrm{~Hz}, 1 \mathrm{H}), 7.31-7.25(\mathrm{~m}, 1 \mathrm{H}), 6.98$ (ddd, $J=8.1,2.8,1.1 \mathrm{~Hz}, 1 \mathrm{H}), 3.83(\mathrm{~s}, 3 \mathrm{H}), 3.77(\mathrm{~s}, 4 \mathrm{H}), 1.03(\mathrm{~s}, 6 \mathrm{H})$.<smiles>CC(=O)c1ccc(B2OCC(C)(C)CO2)cc1</smiles>

1-(4-(5,5-dimethyl-1,3,2-dioxaborinan-2-yl)phenyl)ethan-1-one (1n). General procedure A was employed on a $5 \mathrm{mmol}$ scale for $19 \mathrm{~h}$ and yielded $1.09 \mathrm{~g}$ (94\% yield) of a white solid identified as $\mathbf{1 n}$. The ${ }^{1} \mathrm{H}$ NMR data is consistent with literature ${ }^{9}$ reported data. ${ }^{1} \mathbf{H}$ NMR (500 $\mathrm{MHz}$, chloroform- $\left.d, 23^{\circ} \mathrm{C}\right): \delta 7.95-7.86(\mathrm{~m}, 4 \mathrm{H}), 3.79(\mathrm{~s}, 4 \mathrm{H}), 2.61(\mathrm{~s}, 3 \mathrm{H}), 1.03(\mathrm{~s}, 6 \mathrm{H})$.

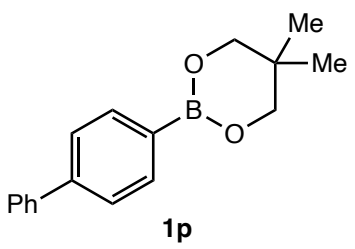


2-([1,1'-biphenyl]-4-yl)-5,5-dimethyl-1,3,2-dioxaborinane (1p). General procedure A was employed on a $10 \mathrm{mmol}$ scale for $17 \mathrm{~h}$ and yielded $2.17 \mathrm{~g}$ (81\% yield) of a white solid identified as $1 \mathrm{p}$. The ${ }^{1} \mathrm{H}$ NMR data is consistent with literature ${ }^{7}$ reported data. ${ }^{1} \mathrm{H}$ NMR $(500 \mathrm{MHz}$, ffchloroform- $\left.d, 23^{\circ} \mathrm{C}\right): \delta 7.88(\mathrm{~d}, J=8.1 \mathrm{~Hz}, 2 \mathrm{H}), 7.66-7.58(\mathrm{~m}, 4 \mathrm{H}), 7.44(\mathrm{t}, J=7.7 \mathrm{~Hz}, 2 \mathrm{H})$, $7.40-7.31(\mathrm{~m}, 1 \mathrm{H}), 3.80(\mathrm{~s}, 4 \mathrm{H}), 1.04(\mathrm{~s}, 6 \mathrm{H})$.

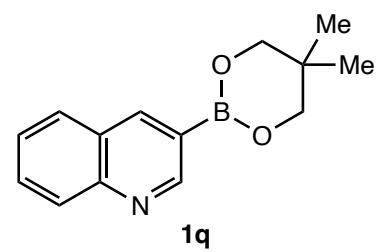

3-(5,5-dimethyl-1,3,2-dioxaborinan-2-yl)quinoline (1q). General procedure A was employed on a $3.5 \mathrm{mmol}$ scale for $21 \mathrm{~h}$. Purification by column chromatography gave a solid mixture of products containing unreacted neopentyl glycol. Recrystallization (DCM/hexane) was used to remove the glycol, leaving $\mathbf{1 q}$ in the filtrate. This process was repeated multiple times, and ultimately yielded $351 \mathrm{mg}$ (42\% yield) of a white solid identified as 1 q. ${ }^{1} \mathbf{H}$ NMR (500 MHz, chloroform- $\left.d, 23^{\circ} \mathrm{C}\right): \delta 9.21(\mathrm{~d}, J=1.8 \mathrm{~Hz}, 1 \mathrm{H}), 8.62-8.58(\mathrm{~m}, 1 \mathrm{H}), 8.11(\mathrm{dt}, J=8.6,0.9 \mathrm{~Hz}$, 1H), $7.84(\mathrm{dd}, J=8.2,1.4 \mathrm{~Hz}, 1 \mathrm{H}), 7.73(\mathrm{ddd}, J=8.4,6.9,1.5 \mathrm{~Hz}, 1 \mathrm{H}), 7.53(\mathrm{ddd}, J=8.1,6.9$, $1.2 \mathrm{~Hz}, 1 \mathrm{H}), 3.84(\mathrm{~s}, 4 \mathrm{H}), 1.06(\mathrm{~s}, 6 \mathrm{H}) \cdot{ }^{13} \mathrm{C}\left\{{ }^{1} \mathrm{H}\right\}$ NMR $\left(126 \mathrm{MHz}\right.$, chloroform-d, $\left.23^{\circ} \mathrm{C}\right)$ : (note: one aromatic carbon signal not observed, likely the carbon attached to boron) $\delta 154.7,149.2,143.5$, 130.4, 129.3, 128.6, 127.8, 126.5, 72.6, 32.2, 22.1. IR (neat, $\mathrm{cm}^{-1}$ ): 3043, 2956, 2871, 1593, 1478, 1336, 1245, 1118, 998, 750, 677. HRMS (ESI-TOF) $\mathrm{m} / \mathrm{z}:[\mathrm{M}+\mathrm{H}]^{+}$Calcd for $\mathrm{C}_{14} \mathrm{H}_{17} \mathrm{BNO}_{2}{ }^{+}$ 241.1383; Found 241.1376.

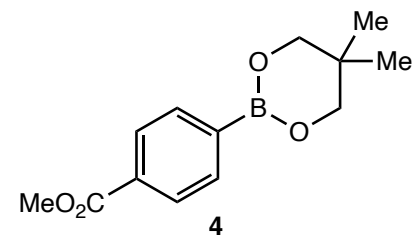


methyl 4-(5,5-dimethyl-1,3,2-dioxaborinan-2-yl)benzoate (4). General procedure A was employed on a $10 \mathrm{mmol}$ scale for $14 \mathrm{~h}$ and yielded $1.99 \mathrm{~g}$ ( $80 \%$ yield) of a white solid identified as 4. The ${ }^{1} \mathrm{H}$ NMR data is consistent with literature ${ }^{8}$ reported data. ${ }^{1} \mathrm{H}$ NMR $(400 \mathrm{MHz}$, chloroform- $\left.d, 23^{\circ} \mathrm{C}\right): \delta 8.04-7.97(\mathrm{~m}, 2 \mathrm{H}), 7.89-7.83(\mathrm{~m}, 2 \mathrm{H}), 3.92(\mathrm{~s}, 3 \mathrm{H}), 3.78(\mathrm{~s}, 4 \mathrm{H}), 1.03$ $(\mathrm{s}, 6 \mathrm{H})$.

\section{Substitution on 1,4-dibromobutane for the synthesis of $2 \mathrm{l}$ and $2 \mathrm{~m}$}

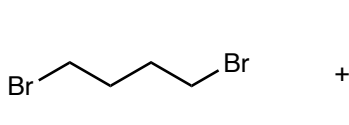

(1.1 equiv)

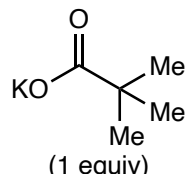

(1 equiv)

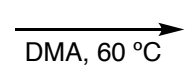

4-bromobutyl pivalate (2I). Potassium pivalate $(1.1 \mathrm{~g}, 8 \mathrm{mmol})$ and DMF $(20 \mathrm{~mL})$ were added to a screw-capped $20 \mathrm{~mL}$ scintillation vial equipped with a magnetic stir bar. 1,4-dibromobutane $\left(1 \mathrm{~mL}, 8.8 \mathrm{mmol}\right.$ ) was then added, and the mixture was allowed to stir overnight at $60{ }^{\circ} \mathrm{C}$ on a hotplate. The next day, the reaction was allowed to cool to room temperature before being diluted with water and ethyl acetate. The layers were separated, and the aqueous layer was further extracted with ethyl acetate two more times. The combined organic layers were dried over sodium sulfate and concentrated. Purification of the crude material by column chromatography (hexanes/ethyl acetate as eluent) gave $907 \mathrm{mg}$ (48\% yield) of a clear oil identified as 21. The ${ }^{1} \mathrm{H}$ NMR data is consistent with literature ${ }^{10}$ reported data. ${ }^{1} \mathbf{H}$ NMR (500 $\mathrm{MHz}$, chloroform- $\left.d, 23^{\circ} \mathrm{C}\right): \delta 4.09(\mathrm{t}, J=6.3 \mathrm{~Hz}, 2 \mathrm{H}), 3.44(\mathrm{t}, J=6.6 \mathrm{~Hz}, 2 \mathrm{H}), 1.98-1.90(\mathrm{~m}$, $2 \mathrm{H}), 1.84-1.76(\mathrm{~m}, 2 \mathrm{H}), 1.20(\mathrm{~s}, 9 \mathrm{H})$.

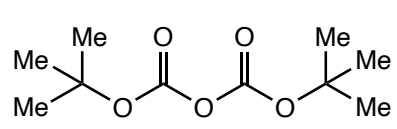

(1 equiv)

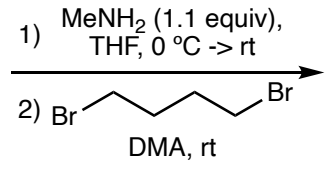

DMA, rt

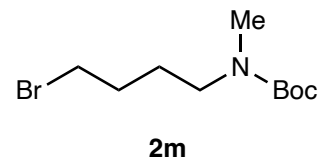

$2 \mathrm{~m}$ 
tert-butyl (4-bromobutyl)(methyl)carbamate $(2 \mathrm{~m})$. A solution of methylamine $(10 \mathrm{~mL}, 2 \mathrm{M}$ in THF) was added to a $100 \mathrm{~mL}$ round bottom flask containing a magnetic stir bar, along with additional THF $(6 \mathrm{~mL})$. The resulting solution was cooled to $0^{\circ} \mathrm{C}$ with an ice bath, prior to the dropwise addition of a solution of di-tert-butyl dicarbonate $(4 \mathrm{~g}, 18.33 \mathrm{mmol})$ in THF (11 $\mathrm{mL})$. The reaction was allowed to warm to room temperature overnight. The next day, the reaction was filtered through a pad of celite that was subsequently washed with ether. Concentration of the filtrate gave a cloudy oil that was used directly in the next step without further purification. DMF (36 mL) and a magnetic stir bar were added to a $100 \mathrm{~mL}$ round bottom flask containing the crude oil, and the resulting solution was cooled to $0^{\circ} \mathrm{C}$. $\mathrm{NaH}(60 \%$ dispersion in mineral oil, 880 $\mathrm{mg}, 22 \mathrm{mmol}$ ) was added and the reaction was allowed to stir for 10 minutes before 1,4dibromobutane $(2.61 \mathrm{~mL}, 22 \mathrm{mmol})$ was added. The reaction was allowed to warm to room temperature overnight. The next day, the reaction was cooled to $0^{\circ} \mathrm{C}$ before being quenched with saturated ammonium chloride and diluted with water and ethyl acetate. The layers were separated, and the aqueous layer was further extracted with ethyl acetate (x2). The combined organics were washed with brine, dried over sodium sulfate and concentrated. Purification of the crude reaction mixture by column chromatography (hexanes/ethyl acetate as eluent) gave 1.36 g (28\% over two steps) of a clear oil that was identified as $2 \mathbf{m} .{ }^{1} \mathbf{H}$ NMR (500 MHz, chloroform- $d$, $\left.23^{\circ} \mathrm{C}\right): 3.43(\mathrm{t}, \mathrm{J}=6.7 \mathrm{~Hz}, 2 \mathrm{H}), 3.29-3.21(\mathrm{~m}, 2 \mathrm{H}), 2.83(\mathrm{~s}, 3 \mathrm{H}), 1.89-1.78(\mathrm{~m}, 2 \mathrm{H}), 1.71-$ $1.61(\mathrm{~m}, 2 \mathrm{H}), 1.45(\mathrm{~s}, 9 \mathrm{H}) \cdot{ }^{13} \mathrm{C}\left\{{ }^{1} \mathrm{H}\right\}$ NMR $\left(126 \mathrm{MHz}\right.$, chloroform-d, $\left.23{ }^{\circ} \mathrm{C}\right)$ : (note: some signals observed as apparent doublets, likely as a consequence of rotomers around the NBoc group in solution. The designation "chemical shift/chemical shift" is used to reflect this observation in the

${ }^{13} \mathrm{C}$ NMR data.) $\delta 155.9,79.5,47.9 / 47.4,34.1,33.7 / 33.4,29.9,28.6,26.6 / 26.3$. IR (neat, $\mathrm{cm}^{-1}$ ): 2973, 2931, 1686, 1391, 1364, 1155, 876, 770. HRMS (ESI-TOF) m/z: [M+Na $]^{+}$Calcd for $\mathrm{C}_{10} \mathrm{H}_{20} \mathrm{BrNO}_{2} \mathrm{Na}^{+}$288.05696; Found 288.05697.

\section{Synthesis of authentic standards for intermolecular radical trap products $7 b$ and $7 c$}



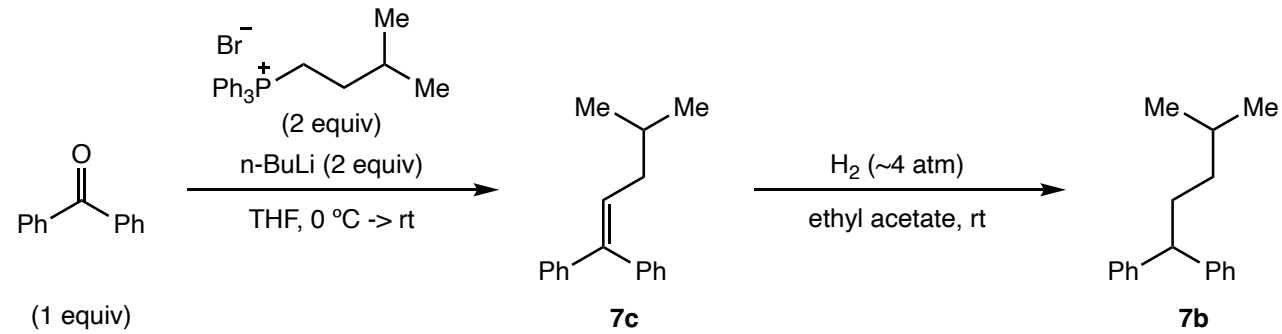

$7 \mathbf{b}$

(4-methylpent-1-ene-1,1-diyl)dibenzene (7c). A $50 \mathrm{~mL}$ round bottom flask containing a magnetic stir bar and a suspension of phosphonium salt $(1.74 \mathrm{~g}, 4.21 \mathrm{mmol})$ in THF $(15 \mathrm{~mL})$ was cooled to $0{ }^{\circ} \mathrm{C}$. Addition of $\mathrm{n}$-butyllithium $(1.7 \mathrm{~mL}, 4.21 \mathrm{mmol}, 2.5 \mathrm{M}$ in hexanes) yielded a dark red solution that was allowed to stir for 20 minutes prior to the addition of benzophenone (384 mg, $2.10 \mathrm{mmol})$ in THF $(2 \mathrm{~mL})$. The resulting solution was allowed to warm to room temperature overnight. The next day, the reaction was diluted with water and ethyl acetate. The layers were separated, and the aqueous layer was further extracted with ethyl acetate (x2). The combined organics were washed with brine, dried over sodium sulfate, and concentrated. Purification of the crude reaction mixture by column chromatography (hexanes as eluent) gave $309 \mathrm{mg}(62 \%)$ of a clear oil that was identified as $7 \mathrm{c}$. The ${ }^{1} \mathrm{H}$ NMR data is consistent with literature ${ }^{11}$ reported data. ${ }^{1} \mathrm{H}$ NMR $\left(500 \mathrm{MHz}\right.$, chloroform- $\left.d, 23^{\circ} \mathrm{C}\right): \delta 7.36(\mathrm{t}, J=7.4 \mathrm{~Hz}, 2 \mathrm{H})$, $7.33-7.19(\mathrm{~m}, 6 \mathrm{H}), 7.17(\mathrm{~d}, J=7.4 \mathrm{~Hz}, 2 \mathrm{H}), 6.11(\mathrm{t}, J=7.5 \mathrm{~Hz}, 1 \mathrm{H}), 2.01(\mathrm{t}, J=7.1 \mathrm{~Hz}, 2 \mathrm{H})$, $1.72(\mathrm{dq}, J=13.5,6.7 \mathrm{~Hz}, 1 \mathrm{H}), 0.90(\mathrm{~d}, J=6.7 \mathrm{~Hz}, 6 \mathrm{H})$.

(4-methylpentane-1,1-diyl)dibenzene (7b). An approximately $170 \mathrm{~mL}$ thick-walled glass vessel containing a magnetic stir bar was charged with $10 \%$ Palladium on carbon (149 mg, $\sim 0.14$ $\mathrm{mmol}$ of $\mathrm{Pd})$, followed by a solution of alkene $7 \mathrm{c}(165 \mathrm{mg}, 0.70 \mathrm{mmol})$ in ethyl acetate $(7 \mathrm{~mL})$. The vessel was frozen in liquid nitrogen, evacuated, and backfilled with 1 atm of hydrogen gas at liquid nitrogen temperature, corresponding to approximately $4 \mathrm{~atm}$ of hydrogen pressure at 23 ${ }^{\circ} \mathrm{C}$. After stirring at room temperature for $4 \mathrm{~h}$, the reaction was filtered over a tightly packed celite plug using ethyl acetate as the eluent. The filtrate was concentrated and purification by 
column chromatography (hexanes as eluent) to give $130 \mathrm{mg}(78 \%)$ of a clear oil that was identified as 7 b. ${ }^{1} \mathbf{H}$ NMR $\left(500 \mathrm{MHz}\right.$, chloroform- $\left.d, 23^{\circ} \mathrm{C}\right): \delta 7.30-7.20(\mathrm{~m}, 8 \mathrm{H}), 7.20-7.13(\mathrm{~m}$, 2H), $3.85(\mathrm{t}, J=7.8 \mathrm{~Hz}, 1 \mathrm{H}), 2.08-2.00(\mathrm{~m}, 2 \mathrm{H}), 1.62-1.48(\mathrm{~m}, 1 \mathrm{H}), 1.15$ (ddd, $J=11.5,7.6$, $5.8 \mathrm{~Hz}, 2 \mathrm{H}), 0.86(\mathrm{~d}, J=6.6 \mathrm{~Hz}, 6 \mathrm{H}) .{ }^{13} \mathrm{C}\left\{{ }^{1} \mathrm{H}\right\}$ NMR $\left(126 \mathrm{MHz}\right.$, chloroform-d, $\left.23{ }^{\circ} \mathrm{C}\right): \delta 145.5$, 128.5, 128.0, 126.1, 51.8, 37.4, 33.7, 28.3, 22.7. IR (neat, $\mathrm{cm}^{-1}$ ): 3025, 2952, 2929, 2868, 1493, 1031, 745, 696. HRMS (El-QTOF) m/z: [M] ${ }^{+}$Calcd for $\mathrm{C}_{18} \mathrm{H}_{22}{ }^{+}$238.17215; Found 238.17207.

\section{Co-Catalyzed Suzuki Coupling}

General Procedure (B): Co-catalyzed Suzuki cross-coupling

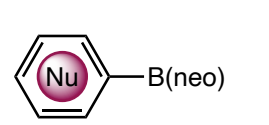

1
(1.5 equiv)

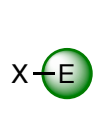

(1 equiv)

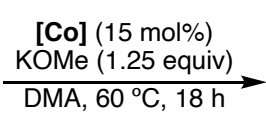

DMA, $60^{\circ} \mathrm{C}, 18 \mathrm{~h}$

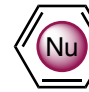

3

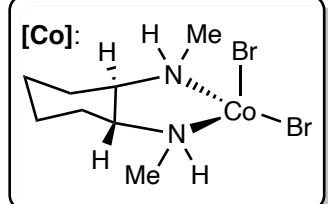

In an $\mathrm{N}_{2}$-filled glovebox, a $20 \mathrm{~mL}$ screw-capped scintillation vial equipped with a magnetic stir bar was charged with KOMe (22 mg, $0.31 \mathrm{mmol}),\left(\mathrm{DMCyDA} \mathrm{CoBr}_{2}(13.5 \mathrm{mg}, 0.038 \mathrm{mmol})\right.$, $\operatorname{ArB}($ neo $) 1(0.375 \mathrm{mmol})$ and DMA $(1.5 \mathrm{~mL})$. This mixture was allowed to stir for 5 minutes at room temperature before alkyl bromide $2(0.25 \mathrm{mmol})$ was added as a solution in DMA $(1 \mathrm{~mL})$. For liquid electrophiles, DMA $(1 \mathrm{~mL})$ was added to the mixture prior to a final microsyringe addition of neat liquid alkyl halide. The vial was capped, sealed with electrical tape, brought out of the glovebox, and placed in a preheated metal block on a hotplate set to $60^{\circ} \mathrm{C}$. After stirring at this temperature for $18 \mathrm{~h}$, the reaction was allowed to cool to room temperature, followed by subsequent dilution with ethyl acetate and water. The layers were separated, and the aqueous layer was extracted with ethyl acetate two more times. The combined organics were washed with brine, dried over sodium sulfate, and concentrated. The crude material was purified by 
silica gel column chromatography (hexanes/ethyl acetate as eluent) to afford cross-coupled product 3 .

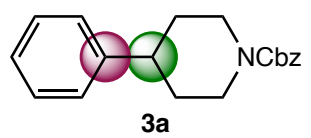

benzyl 4-phenylpiperidine-1-carboxylate (3a). General procedure B was employed using 1a and $2 \mathrm{a}$ with a slight modification. The yield of $3 \mathbf{a}$ was measured to be $69 \%$ by UPLC of the crude reaction mixture using 1,3,5-tri-tert-butylbenzene as an internal standard. The reaction was diluted with $2 \mathrm{M} \mathrm{NaOH}$ instead of water, and ethyl acetate. The basic aqueous solution was further extracted with ethyl acetate two more times. The combined organics were sequentially washed with water and brine, dried over sodium sulfate, and concentrated. Purification of the crude mixture by column chromatography (hexanes/ethyl acetate as eluent) afforded a clear oil identified as a mixture of compounds containing 3a. An ethyl acetate solution of this mixture was sequentially washed with $2 \mathrm{M} \mathrm{NaOH}$ two times before being dried over sodium sulfate and concentrated. Additional purification by preparative supercritical fluid chromatography afforded a clear oil that was identified as an analytically pure sample of $3 a$. The ${ }^{1} \mathrm{H}$ NMR data is consistent with literature ${ }^{12}$ reported data. ${ }^{1} \mathrm{H}$ NMR $\left(500 \mathrm{MHz}\right.$, chloroform-d, $\left.23{ }^{\circ} \mathrm{C}\right): \delta 7.41-7.35(\mathrm{~m}, 4 \mathrm{H})$, $7.35-7.28(\mathrm{~m}, 3 \mathrm{H}), 7.25-7.17(\mathrm{~m}, 3 \mathrm{H}), 5.16(\mathrm{~s}, 2 \mathrm{H}), 4.34(\mathrm{~s}, 2 \mathrm{H}), 2.89(\mathrm{~s}, 2 \mathrm{H}), 2.67(\mathrm{tt}, J=$ 12.2, 3.6 Hz, $1 \mathrm{H}), 1.85(\mathrm{~d}, J=13.1 \mathrm{~Hz}, 2 \mathrm{H}), 1.68-1.62(\mathrm{~m}, 2 \mathrm{H})$.

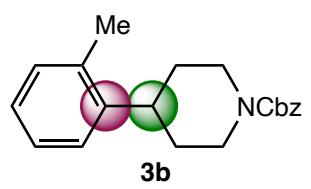

benzyl 4-(o-tolyl)piperidine-1-carboxylate (3b). General procedure B was employed using 1b and $2 \mathrm{a}$ with a slight modification. The reaction was diluted with $2 \mathrm{M} \mathrm{NaOH}$ instead of water, and ethyl acetate. The basic aqueous solution was further extracted with ethyl acetate two more 
times. The combined organics were sequentially washed with water and brine, dried over sodium sulfate, and concentrated. The yield of $3 \mathbf{b}$ was measured to be $70 \%$ by ${ }^{1} \mathrm{H}$ NMR of the crude reaction mixture using mesitylene as an internal standard. Purification of the crude mixture by column chromatography (hexanes/ethyl acetate as eluent) afforded a clear oil that was identified as an analytically pure sample of $\mathbf{3 b}$. ${ }^{1} \mathbf{H}$ NMR $\left(500 \mathrm{MHz}\right.$, chloroform- $\left.d, 23^{\circ} \mathrm{C}\right): \delta$ $7.42-7.29(\mathrm{~m}, 5 \mathrm{H}), 7.22-7.08(\mathrm{~m}, 4 \mathrm{H}), 5.17(\mathrm{~s}, 2 \mathrm{H}), 4.47-4.24(\mathrm{~m}, 2 \mathrm{H}), 3.02-2.79(\mathrm{~m}, 1 \mathrm{H})$, $2.35(\mathrm{~s}, 3 \mathrm{H}), 1.83-1.58(\mathrm{~m}, 4 \mathrm{H}) .{ }^{13} \mathrm{C}\left\{{ }^{1} \mathrm{H}\right\}$ NMR $\left(126 \mathrm{MHz}\right.$, chloroform- $\left.d, 23{ }^{\circ} \mathrm{C}\right): \delta 155.5,143.5$, 137.0, 135.2, 130.6, 128.6, 128.12, 128.05, 126.5, 126.2, 125.5, 67.2, 45.0, 38.4, 32.5, 19.5. IR (neat, $\left.\mathrm{cm}^{-1}\right): 3028,2937,2851,1692,1426,1276,1218,1127,1014,750,725,696$. HRMS (ESI-TOF) m/z: [M+H] ${ }^{+}$Calcd for $\mathrm{C}_{20} \mathrm{H}_{24} \mathrm{NO}_{2}{ }^{+}$310.1802; Found 310.1798.

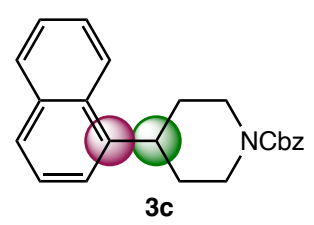

benzyl 4-(naphthalen-1-yl)piperidine-1-carboxylate (3c). General procedure B was employed using $1 \mathrm{c}$ and $2 \mathrm{a}$ with a slight modification. The reaction was diluted with $2 \mathrm{M} \mathrm{NaOH}$ instead of water, and ethyl acetate. The basic aqueous solution was further extracted with ethyl acetate two more times. The combined organics were sequentially washed with water and brine, dried over sodium sulfate, and concentrated. Purification of the crude mixture by column chromatography (hexanes/ethyl acetate as eluent) afforded a clear oil. An ethyl acetate/hexane solution of this oil was again washed with $2 \mathrm{M} \mathrm{NaOH}$, dried over sodium sulfate and concentrated to give $55 \mathrm{mg}$ (64\% yield) of a clear oil identified as $3 \mathbf{c} .{ }^{1} \mathbf{H}$ NMR $(500 \mathrm{MHz}$, chloroform- $\left.d, 23^{\circ} \mathrm{C}\right): \delta 8.10(\mathrm{~d}, J=8.4 \mathrm{~Hz}, 1 \mathrm{H}), 7.90-7.85(\mathrm{~m}, 1 \mathrm{H}), 7.74(\mathrm{~d}, J=8.2 \mathrm{~Hz}, 1 \mathrm{H})$, $7.56-7.31(\mathrm{~m}, 9 \mathrm{H}), 5.19(\mathrm{~s}, 2 \mathrm{H}), 4.52-4.31(\mathrm{~m}, 2 \mathrm{H}), 3.51(\mathrm{tt}, J=12.1,3.3 \mathrm{~Hz}, 1 \mathrm{H}), 3.14-$ $2.96(\mathrm{~m}, 2 \mathrm{H}), 2.07-1.94(\mathrm{~m}, 2 \mathrm{H}), 1.85-1.74(\mathrm{~m}, 2 \mathrm{H}) .{ }^{13} \mathrm{C}\left\{{ }^{1} \mathrm{H}\right\}$ NMR (126 MHz, chloroform-d, $\left.23^{\circ} \mathrm{C}\right): \delta 155.5,141.3,137.0,134.1,131.2,129.3,128.7,128.14,128.06,127.0,126.1,125.8$, 
125.6, 122.8, 122.6, 67.3, 45.1, 37.6, 33.0. IR (neat, $\mathrm{cm}^{-1}$ ): 3046, 2939, 2852, 1689, 1426, 1220, 1117, 777, 732, 697. HRMS (ESI-TOF) $\mathrm{m} / \mathrm{z}$ : $[\mathrm{M}+\mathrm{H}]^{+}$Calcd for $\mathrm{C}_{23} \mathrm{H}_{24} \mathrm{NO}_{2}{ }^{+}$346.1802; Found 346.1788.

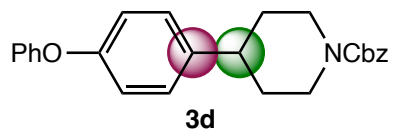

benzyl 4-(4-phenoxyphenyl)piperidine-1-carboxylate (3d). General procedure B was employed using $\mathbf{1 d}$ and $\mathbf{2 a}$ with a slight modification. Purification of the crude mixture by column chromatography (hexanes/ethyl acetate as eluent) afforded a clear oil that was subjected to the following washing procedure: an ethyl acetate/hexane solution of the oil was washed with $2 \mathrm{M}$ $\mathrm{NaOH}$, dried over sodium sulfate and concentrated. This washing procedure was repeated twice to give $51 \mathrm{mg}$ (53\% yield) of a clear oil identified as $\mathbf{3 d} .{ }^{1} \mathbf{H}$ NMR (500 MHz, chloroform-d, 23 $\left.{ }^{\circ} \mathrm{C}\right): \delta 7.41-7.29(\mathrm{~m}, 7 \mathrm{H}), 7.17-7.13(\mathrm{~m}, 2 \mathrm{H}), 7.09(\mathrm{tt}, J=7.5,1.2 \mathrm{~Hz}, 1 \mathrm{H}), 7.03-6.97(\mathrm{~m}$, $2 \mathrm{H}), 6.97-6.93(\mathrm{~m}, 2 \mathrm{H}), 5.16(\mathrm{~s}, 2 \mathrm{H}), 4.42-4.25(\mathrm{~m}, 2 \mathrm{H}), 2.96-2.78(\mathrm{~m}, 2 \mathrm{H}), 2.66(\mathrm{tt}, \mathrm{J}=$ 12.2, 3.6 Hz, $1 \mathrm{H}), 1.92-1.76(\mathrm{~m}, 2 \mathrm{H}), 1.69-1.56(\mathrm{~m}, 2 \mathrm{H}) .{ }^{13} \mathrm{C}\left\{{ }^{1} \mathrm{H}\right\}$ NMR $(126 \mathrm{MHz}$, chloroform$\left.d, 23{ }^{\circ} \mathrm{C}\right): \delta 157.5,155.8,155.4,140.6,137.0,129.9,128.6,128.13,128.06,128.05,123.3$, 119.1, 118.9, 67.2, 44.7, 42.1, 33.4. IR (neat, $\left.\mathrm{cm}^{-1}\right): 3032,2919,2850,1692,1488,1218,1120$, 1013, 868, 747, 693. HRMS (ESI-TOF) $\mathrm{m} / \mathrm{z}$ : $[\mathrm{M}+\mathrm{H}]^{+}$Calcd for $\mathrm{C}_{25} \mathrm{H}_{26} \mathrm{NO}_{3}{ }^{+}$388.1907; Found 388.1902.

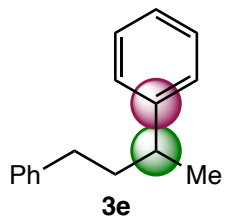

butane-1,3-diyldibenzene (3e). General procedure B was employed using 1 a and $\mathbf{2 e - g . ~}$ Purification of the crude mixture by column chromatography (hexanes as eluent) afforded $32 \mathrm{mg}$ $(60 \%$ yield $)$ of a clear oil identified as $3 e$. The ${ }^{1} \mathrm{H}$ NMR data is consistent with literature ${ }^{13}$ 
reported data. ${ }^{1} \mathrm{H}$ NMR $\left(500 \mathrm{MHz}\right.$, chloroform-d, $\left.23^{\circ} \mathrm{C}\right)$ : $\delta 7.35-7.11(\mathrm{~m}, 10 \mathrm{H}), 2.78-2.67(\mathrm{~m}$, 1H), $2.58-2.45(\mathrm{~m}, 2 \mathrm{H}), 2.00-1.84(\mathrm{~m}, 2 \mathrm{H}), 1.28(\mathrm{~d}, J=7.0 \mathrm{~Hz}, 3 \mathrm{H})$.

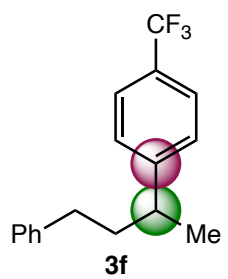

1-(4-phenylbutan-2-yl)-4-(trifluoromethyl)benzene (3f). General procedure B was employed using $1 \mathbf{f}$ and $\mathbf{2 e}-\mathbf{g}$. Purification of the crude mixture by column chromatography (hexanes as eluent) afforded $39 \mathrm{mg}$ (56\% yield) of a clear oil identified as $3 \mathrm{f}$. The ${ }^{1} \mathrm{H}$ NMR data is consistent with literature ${ }^{14}$ reported data. ${ }^{1} \mathrm{H}$ NMR $\left(500 \mathrm{MHz}\right.$, chloroform- $\left.d, 23^{\circ} \mathrm{C}\right): \delta 7.57(\mathrm{~d}, J=8.1 \mathrm{~Hz}$, 2H), $7.34-7.24(\mathrm{~m}, 4 \mathrm{H}), 7.22-7.15(\mathrm{~m}, 1 \mathrm{H}), 7.15-7.10(\mathrm{~m}, 2 \mathrm{H}), 2.85-2.74(\mathrm{~m}, 1 \mathrm{H}), 2.58-$ $2.44(\mathrm{~m}, 2 \mathrm{H}), 1.99-1.88(\mathrm{~m}, 2 \mathrm{H}), 1.29(\mathrm{~d}, \mathrm{~J}=6.9 \mathrm{~Hz}, 3 \mathrm{H})$.

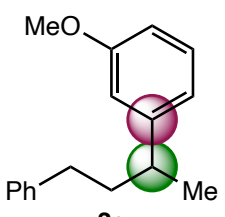

$3 g$

1-methoxy-3-(4-phenylbutan-2-yl)benzene (3g). General procedure B was employed using $1 \mathrm{~g}$ and $\mathbf{2 e - g}$. Purification of the crude mixture by column chromatography (hexanes/ethyl acetate as eluent) afforded $36 \mathrm{mg}\left(60 \%\right.$ yield) of a clear oil identified as $\mathbf{3 g}$. The ${ }^{1} \mathrm{H}$ NMR data is consistent with literature ${ }^{15}$ reported data. ${ }^{1} \mathrm{H}$ NMR $\left(500 \mathrm{MHz}\right.$, chloroform-d, $\left.23^{\circ} \mathrm{C}\right): \delta 7.30-$ $7.21(\mathrm{~m}, 3 \mathrm{H}), 7.20-7.12(\mathrm{~m}, 3 \mathrm{H}), 6.82(\mathrm{~d}, J=7.6 \mathrm{~Hz}, 1 \mathrm{H}), 6.79-6.73(\mathrm{~m}, 2 \mathrm{H}), 3.82(\mathrm{~s}, 3 \mathrm{H})$, $2.75-2.65(\mathrm{~m}, 1 \mathrm{H}), 2.53(\mathrm{td}, J=7.7,6.5,2.5 \mathrm{~Hz}, 2 \mathrm{H}), 1.99-1.83(\mathrm{~m}, 2 \mathrm{H}), 1.27(\mathrm{~d}, J=7.0 \mathrm{~Hz}$, $3 \mathrm{H})$. 


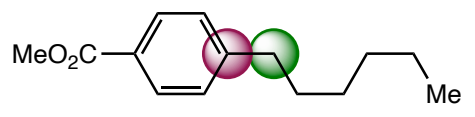

$3 h$

methyl 4-hexylbenzoate (3h). General procedure B was employed using 4 and $\mathbf{2 h}$. Purification of the crude mixture by column chromatography (hexanes/ethyl acetate as eluent) afforded 40 mg $(73 \%$ yield $)$ of a clear oil identified as $3 \mathbf{h}$. The ${ }^{1} \mathrm{H}$ NMR data is consistent with literature ${ }^{16}$ reported data. ${ }^{1} \mathrm{H}$ NMR $\left(500 \mathrm{MHz}\right.$, chloroform- $\left.d, 23^{\circ} \mathrm{C}\right): \delta 7.94(\mathrm{~d}, J=8.1 \mathrm{~Hz}, 2 \mathrm{H}), 7.24(\mathrm{~d}, J=$ $8.0 \mathrm{~Hz}, 2 \mathrm{H}), 3.90(\mathrm{~s}, 3 \mathrm{H}), 2.65(\mathrm{t}, J=7.8 \mathrm{~Hz}, 2 \mathrm{H}), 1.62(\mathrm{dq}, J=15.2,7.5,6.8 \mathrm{~Hz}, 2 \mathrm{H}), 1.37-$ $1.24(\mathrm{~m}, 6 \mathrm{H}), 0.93-0.83(\mathrm{~m}, 3 \mathrm{H})$.

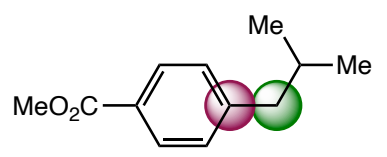

$3 \mathbf{i}$

methyl 4-isobutylbenzoate (3i). General procedure B was employed using 4 and $\mathbf{2 i}$ Purification of the crude mixture by column chromatography (hexanes/ethyl acetate as eluent) afforded $25 \mathrm{mg}\left(52 \%\right.$ yield) of a clear oil identified as $3 \mathbf{i}$. The ${ }^{1} \mathrm{H}$ NMR data is consistent with literature ${ }^{17}$ reported data. ${ }^{1} \mathrm{H}$ NMR $\left(500 \mathrm{MHz}\right.$, chloroform-d, $\left.23^{\circ} \mathrm{C}\right): \delta 7.98-7.92(\mathrm{~m}, 2 \mathrm{H}), 7.23-$ $7.18(\mathrm{~m}, 2 \mathrm{H}), 3.90(\mathrm{~s}, 3 \mathrm{H}), 2.53(\mathrm{~d}, J=7.2 \mathrm{~Hz}, 2 \mathrm{H}), 1.89(\mathrm{dq}, J=13.5,6.8 \mathrm{~Hz}, 1 \mathrm{H}), 0.90(\mathrm{~d}, J=$ $6.6 \mathrm{~Hz}, 6 \mathrm{H})$.

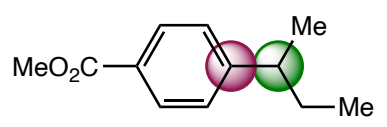

3j

methyl 4-(sec-butyl)benzoate (3j). General procedure B was employed using 4 and $\mathbf{2 j}$. Purification of the crude mixture by column chromatography (hexanes/ethyl acetate as eluent) afforded $22 \mathrm{mg}$ (46\% yield) of a clear oil identified as $\mathbf{3 j}$. The ${ }^{1} \mathrm{H}$ NMR data is consistent with 
literature ${ }^{18}$ reported data. ${ }^{1} \mathrm{H}$ NMR $\left(500 \mathrm{MHz}\right.$, chloroform- $\left.d, 23^{\circ} \mathrm{C}\right): \delta 7.99-7.93(\mathrm{~m}, 2 \mathrm{H}), 7.27$ $-7.22(\mathrm{~m}, 2 \mathrm{H}), 3.90(\mathrm{~s}, 3 \mathrm{H}), 2.71-2.61(\mathrm{~m}, 1 \mathrm{H}), 1.61(\mathrm{p}, J=7.4 \mathrm{~Hz}, 2 \mathrm{H}), 1.25(\mathrm{~d}, J=6.9 \mathrm{~Hz}$, $3 \mathrm{H}), 0.81(\mathrm{t}, J=7.4 \mathrm{~Hz}, 3 \mathrm{H})$.

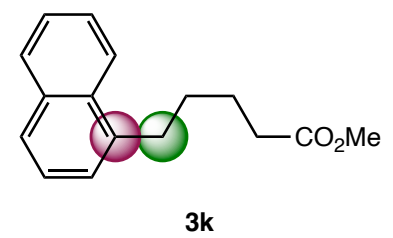

methyl 5-(naphthalen-1-yl)pentanoate (3k). General procedure B was employed using 1c and 2k. Purification of the crude mixture by column chromatography (hexanes/ethyl acetate as eluent) afforded $39 \mathrm{mg}$ (64\% yield) of a clear oil identified as $\mathbf{3 k}$. This reaction was also conducted on 4 times the scale ( $1 \mathrm{mmol}$ of electrophile) with a slight modification. An ethyl acetate solution of the material isolated following chromatographic purification was diluted with $2 \mathrm{M} \mathrm{NaOH}$ and the layers were separated. The organic layer was dried over sodium sulfate and concentrated to give $174 \mathrm{mg}$ ( $72 \%$ yield) of a pale-yellow oil identified as $\mathbf{3 k}$. The ${ }^{1} \mathrm{H}$ NMR data is consistent with literature ${ }^{19}$ reported data. ${ }^{1} \mathrm{H}$ NMR $\left(500 \mathrm{MHz}\right.$, chloroform- $\left.d, 23^{\circ} \mathrm{C}\right): \delta 8.02(\mathrm{~d}$, $J=8.3 \mathrm{~Hz}, 1 \mathrm{H}), 7.85(\mathrm{dd}, J=8.0,1.7 \mathrm{~Hz}, 1 \mathrm{H}), 7.71(\mathrm{~d}, J=8.2 \mathrm{~Hz}, 1 \mathrm{H}), 7.55-7.44(\mathrm{~m}, 2 \mathrm{H})$, $7.39(\mathrm{dd}, J=8.2,6.9 \mathrm{~Hz}, 1 \mathrm{H}), 7.32(\mathrm{~d}, J=7.0 \mathrm{~Hz}, 1 \mathrm{H}), 3.67(\mathrm{~s}, 3 \mathrm{H}), 3.13-3.06(\mathrm{~m}, 2 \mathrm{H}), 2.41-$ $2.34(\mathrm{~m}, 2 \mathrm{H}), 1.83-1.76(\mathrm{~m}, 4 \mathrm{H})$.

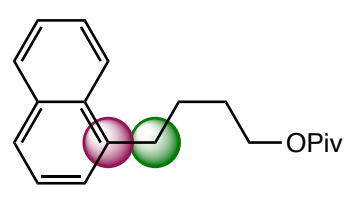

3I

4-(naphthalen-1-yl)butyl pivalate (3l). General procedure B was employed using 1c and 2 I. Purification of the crude mixture by column chromatography (hexanes/ethyl acetate as eluent) afforded $43 \mathrm{mg}\left(60 \%\right.$ yield) of a clear oil identified as 3 I. ${ }^{1} \mathrm{H}$ NMR $(500 \mathrm{MHz}$, chloroform- $d, 23$ 
$\left.{ }^{\circ} \mathrm{C}\right): \delta 8.05-8.00(\mathrm{~m}, 1 \mathrm{H}), 7.89-7.81(\mathrm{~m}, 1 \mathrm{H}), 7.72(\mathrm{~d}, J=8.2 \mathrm{~Hz}, 1 \mathrm{H}), 7.54-7.44(\mathrm{~m}, 2 \mathrm{H})$, $7.40(\mathrm{dd}, J=8.2,7.0 \mathrm{~Hz}, 1 \mathrm{H}), 7.32(\mathrm{dd}, J=7.0,1.2 \mathrm{~Hz}, 1 \mathrm{H}), 4.12(\mathrm{t}, J=6.3 \mathrm{~Hz}, 2 \mathrm{H}), 3.11(\mathrm{t}, J=$ $7.6 \mathrm{~Hz}, 2 \mathrm{H}), 1.89-1.73(\mathrm{~m}, 4 \mathrm{H}), 1.19(\mathrm{~s}, 9 \mathrm{H}) .{ }^{13} \mathrm{C}\left\{{ }^{1} \mathrm{H}\right\}$ NMR (126 MHz, chloroform-d, $\left.23^{\circ} \mathrm{C}\right): \delta$ $178.8,138.3,134.0,131.9,128.9,126.8,126.1,125.9,125.7,125.6,123.9,64.2,38.9,32.8$, 28.8, 27.4, 27.2. IR (neat, $\mathrm{cm}^{-1}$ ): 3045, 2955, 2869, 1723, 1479, 1282, 1150, 775. HRMS (ESITOF) $\mathrm{m} / \mathrm{z}:[\mathrm{M}+\mathrm{H}]^{+}$Calcd for $\mathrm{C}_{19} \mathrm{H}_{25} \mathrm{O}_{2}{ }^{+}$285.1849; Found 285.1848 .

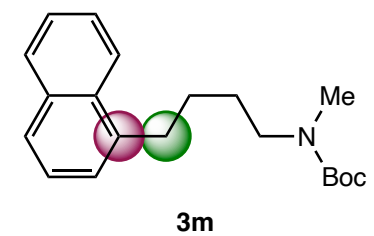

tert-butyl methyl(4-(naphthalen-1-yl)butyl)carbamate $(3 \mathrm{~m})$. General procedure B was employed using $1 \mathrm{c}$ and $\mathbf{2 m}$. Purification of the crude mixture by column chromatography (hexanes/ethyl acetate as eluent) afforded an impure mixture containing $3 \mathrm{~m}$. An ethyl acetate/hexane solution of this mixture was washed with $2 \mathrm{M} \mathrm{NaOH}(x 2)$, dried over sodium sulfate and concentrated. Additional purification by column chromatography afforded $39 \mathrm{mg}$ ( $50 \%$ yield) of a clear oil identified as $3 \mathrm{~m} .{ }^{1} \mathbf{H}$ NMR $\left(500 \mathrm{MHz}\right.$, chloroform- $\left.d, 23^{\circ} \mathrm{C}\right): \delta 8.03(\mathrm{~d}, J$ $=8.2 \mathrm{~Hz}, 1 \mathrm{H}), 7.85(\mathrm{dd}, J=7.9,1.6 \mathrm{~Hz}, 1 \mathrm{H}), 7.71(\mathrm{~d}, J=8.2 \mathrm{~Hz}, 1 \mathrm{H}), 7.55-7.44(\mathrm{~m}, 2 \mathrm{H}), 7.44$ - $7.36(\mathrm{~m}, 1 \mathrm{H}), 7.32(\mathrm{~d}, J=6.9 \mathrm{~Hz}, 1 \mathrm{H}), 3.28-3.22(\mathrm{~m}, 2 \mathrm{H}), 3.15-3.06(\mathrm{~m}, 2 \mathrm{H}), 2.82(\mathrm{~s}, 3 \mathrm{H})$, $1.81-1.70(\mathrm{~m}, 2 \mathrm{H}), 1.69-1.58(\mathrm{~m}, 2 \mathrm{H}), 1.44(\mathrm{~s}, 9 \mathrm{H}) .{ }^{13} \mathrm{C}\left\{{ }^{1} \mathrm{H}\right\}$ NMR (126 MHz, chloroform-d, 23 $\left.{ }^{\circ} \mathrm{C}\right): \delta 156.0,138.5,134.0,132.0,128.9,126.7,126.1,125.9,125.6,125.6,123.9,79.3,48.7$, 34.3, 32.8, 28.6, 27.9 (two carbons observed by HSQC). IR (neat, $\mathrm{cm}^{-1}$ ): 3045, 2973, 2930, 2862, 1687, 1391, 1156, 877, 775. HRMS (ESI-TOF) $\mathrm{m} / \mathrm{z}$ : $[\mathrm{M}+\mathrm{Na}]^{+}$Calcd for $\mathrm{C}_{20} \mathrm{H}_{27} \mathrm{NO}_{2} \mathrm{Na}^{+}$ 336.1934; Found 336.1936. 


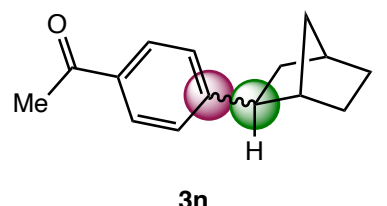

(士)-1-(4-(Bicyclo[2.2.1]heptan-2-yl)phenyl)ethenone (3n). General procedure B was employed using $\mathbf{1 n}$ and $\mathbf{2 n}$. The diastereomeric ratio (dr) of 4:1 (major shown) was established from crude ${ }^{1} \mathrm{H}$ NMR by relative integration of the benzylic methine signals for each diastereomer. Purification of the crude mixture by column chromatography (hexanes/ethyl acetate as eluent) afforded $29 \mathrm{mg}$ (54\% yield, 7:1 isolated $\mathrm{dr}$ ) of a clear oil identified as $\mathbf{3 n}$. The ${ }^{1} \mathrm{H}$ and ${ }^{13} \mathrm{C}$ NMR data are consistent with literature ${ }^{20}$ reported data for the major diastereomer. ${ }^{1} \mathrm{H}$ NMR (for the major diastereomer; $500 \mathrm{MHz}$, chloroform-d, $23^{\circ} \mathrm{C}$ ): $\delta 7.89-7.86(\mathrm{~m}, 2 \mathrm{H}$ ), $7.33-7.27(\mathrm{~m}, 2 \mathrm{H}), 2.79(\mathrm{dd}, J=9.1,5.6 \mathrm{~Hz}, 1 \mathrm{H}), 2.58(\mathrm{~s}, 3 \mathrm{H}), 2.41-2.34(\mathrm{~m}, 2 \mathrm{H}), 1.81$ (ddd, $J=11.9,9.2,2.4 \mathrm{~Hz}, 1 \mathrm{H}), 1.67-1.54(\mathrm{~m}, 2 \mathrm{H}), 1.53-1.49(\mathrm{~m}, 1 \mathrm{H}), 1.38(\mathrm{ddd}, J=10.3,6.9,2.4$ $\mathrm{Hz}, 1 \mathrm{H}), 1.32-1.19(\mathrm{~m}, 3 \mathrm{H}) .{ }^{1} \mathrm{H}$ NMR (isolated signals for the minor diastereomer; $500 \mathrm{MHz}$, chloroform-d, $\left.23{ }^{\circ} \mathrm{C}\right): \delta 3.33-3.20(\mathrm{~m}, 1 \mathrm{H}), 2.05-1.96(\mathrm{~m}, 1 \mathrm{H}) .{ }^{13} \mathrm{C}\left\{{ }^{1} \mathrm{H}\right\}$ NMR (for the major diastereomer; $126 \mathrm{MHz}$, chloroform- $d, 23^{\circ} \mathrm{C}$ ): $\delta$ 198.1, 153.6, 134.7, 128.6, 127.4, 47.6, 42.9, 39.3, 37.0, 36.3, 30.7, 28.9, 26.7. ${ }^{3} \mathbf{C}\left\{{ }^{1} \mathrm{H}\right\}$ NMR (isolated signals for the minor diastereomer; 126 $\mathrm{MHz}$, chloroform- $d, 23^{\circ} \mathrm{C}$ ): $\delta 128.5,128.3,46.3,42.7,40.7,37.6,34.3,30.2,23.1$. IR (neat, $\mathrm{cm}^{-}$ 1): 2948, 2868, 1679, 1604, 1357, 1268, 955, 823. HRMS (ESI-TOF) m/z: $[M+H]^{+}$Calcd for $\mathrm{C}_{15} \mathrm{H}_{19} \mathrm{O}^{+} 215.1430 ;$ Found 215.1434.

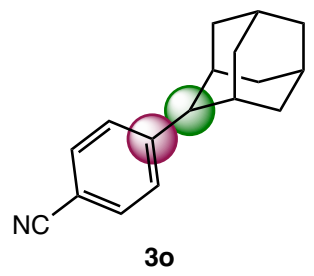

4-((1r,3r,5r,7r)-adamantan-2-yl)benzonitrile (30). General procedure B was employed using 10 and 20. Purification of the crude mixture by column chromatography (hexanes/ethyl acetate 
as eluent) afforded $22 \mathrm{mg}\left(37 \%\right.$ yield) of a white solid identified as $30 .{ }^{1} \mathbf{H}$ NMR $(500 \mathrm{MHz}$, chloroform-d, $\left.23^{\circ} \mathrm{C}\right): \delta 7.64-7.58(\mathrm{~m}, 2 \mathrm{H}), 7.49-7.43(\mathrm{~m}, 2 \mathrm{H}), 3.02(\mathrm{~s}, 1 \mathrm{H}), 2.49-2.44(\mathrm{~m}$, $2 \mathrm{H}), 2.07-1.98(\mathrm{~m}, 3 \mathrm{H}), 1.98-1.91(\mathrm{~m}, 2 \mathrm{H}), 1.83-1.69(\mathrm{~m}, 5 \mathrm{H}), 1.62-1.55(\mathrm{~m}, 2 \mathrm{H}) .{ }^{13} \mathrm{C}\left\{{ }^{1} \mathrm{H}\right\}$ NMR (126 MHz, chloroform-d, $\left.23^{\circ} \mathrm{C}\right): \delta 150.5,132.1,127.9,119.4,109.1,77.4,77.2,76.9$, 47.2, 39.1, 37.7, 32.0, 31.1, 27.9, 27.7. IR (neat, $\mathrm{cm}^{-1}$ ): 3075, 3062, 2900, 2847, 2227, 1606, 857, 834, 736. HRMS (ESI-TOF) $m / z$ : $[\mathrm{M}+\mathrm{H}]^{+}$Calcd for $\mathrm{C}_{17} \mathrm{H}_{20} \mathrm{~N}^{+}$238.1590; Found 238.1583.

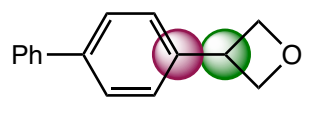

$3 p$

3-([1,1'-biphenyl]-4-yl)oxetane (3p). General procedure B was employed using $1 p$ and 2p with a slight modification. The reaction was diluted with $2 \mathrm{M} \mathrm{NaOH}$ instead of water, and ethyl acetate. The basic aqueous solution was further extracted with ethyl acetate two more times. The combined organics were sequentially washed with brine, dried over sodium sulfate, and concentrated. Purification of the crude mixture by column chromatography (hexanes/ethyl acetate as eluent) afforded an hexanes/ethyl acetate solution containing $3 p$ that was washed with $2 \mathrm{M} \mathrm{NaOH}$ (3 times), dried over sodium sulfate and concentrated. A hexane/DCM suspension of the resulting white solid was filtered through cotton and the filtrate was concentrated to give $27 \mathrm{mg}$ ( $51 \%$ yield) of a white solid identified as $3 \mathrm{p}$. The ${ }^{1} \mathrm{H}$ NMR data is consistent with literature ${ }^{21}$ reported data. ${ }^{1} \mathrm{H}$ NMR (500 MHz, chloroform-d, $\left.23^{\circ} \mathrm{C}\right): \delta 7.64-7.57$ $(\mathrm{m}, 4 \mathrm{H}), 7.51-7.41(\mathrm{~m}, 4 \mathrm{H}), 7.38-7.32(\mathrm{~m}, 1 \mathrm{H}), 5.11(\mathrm{dd}, J=8.4,6.0 \mathrm{~Hz}, 2 \mathrm{H}), 4.83(\mathrm{t}, J=6.4$ $\mathrm{Hz}, 2 \mathrm{H}), 4.33-4.24(\mathrm{~m}, 1 \mathrm{H})$.

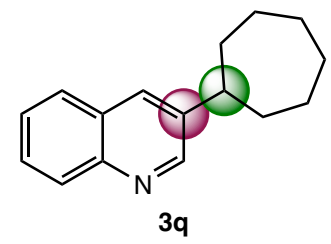


3-cycloheptylquinoline (3q). General procedure B was employed using $\mathbf{1 q}$ and $\mathbf{2 q}$. Purification of the crude mixture by column chromatography (hexanes/ethyl acetate as eluent) afforded 32 mg $(57 \%$ yield $)$ of a clear oil identified as $3 q$. The ${ }^{1} \mathrm{H}$ NMR data is consistent with literature ${ }^{12}$ reported data. ${ }^{1} \mathrm{H}$ NMR $\left(500 \mathrm{MHz}\right.$, chloroform-d, $\left.23^{\circ} \mathrm{C}\right): \delta 8.83-8.79(\mathrm{~m}, 1 \mathrm{H}), 8.09(\mathrm{~d}, J=8.5$ $\mathrm{Hz}, 1 \mathrm{H}), 7.95-7.91(\mathrm{~m}, 1 \mathrm{H}), 7.78(\mathrm{~d}, J=8.2 \mathrm{~Hz}, 1 \mathrm{H}), 7.69-7.62(\mathrm{~m}, 1 \mathrm{H}), 7.53(\mathrm{t}, J=7.5 \mathrm{~Hz}$, 1H), $2.90(\mathrm{tt}, J=10.6,3.8 \mathrm{~Hz}, 1 \mathrm{H}), 2.06-1.97(\mathrm{~m}, 2 \mathrm{H}), 1.92-1.82(\mathrm{~m}, 2 \mathrm{H}), 1.82-1.70(\mathrm{~m}$, $4 \mathrm{H}), 1.70-1.57(\mathrm{~m}, 4 \mathrm{H})$.

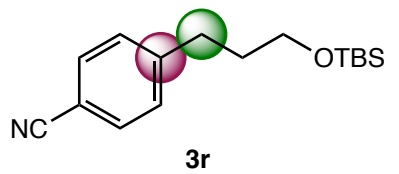

4-(3-((tert-butyldimethylsilyl)oxy)propyl)benzonitrile (3r). General procedure B was employed using $1 \mathbf{r}$ and $2 \mathbf{r}$. Purification of the crude mixture by column chromatography (hexanes/ethyl acetate as eluent) afforded $30 \mathrm{mg}\left(44 \%\right.$ yield) of a clear oil identified as $3 \mathrm{r} .{ }^{1} \mathbf{H}$ NMR (500 MHz, chloroform- $\left.d, 23^{\circ} \mathrm{C}\right): \delta 7.59-7.53(\mathrm{~m}, 2 \mathrm{H}), 7.33-7.26(\mathrm{~m}, 2 \mathrm{H}), 3.61(\mathrm{t}, \mathrm{J}=$ $6.1 \mathrm{~Hz}, 2 \mathrm{H}), 2.78-2.71(\mathrm{~m}, 2 \mathrm{H}), 1.88-1.78(\mathrm{~m}, 2 \mathrm{H}), 0.90(\mathrm{~s}, 9 \mathrm{H}), 0.04(\mathrm{~s}, 6 \mathrm{H}) .{ }^{13} \mathrm{C}\left\{{ }^{1} \mathrm{H}\right\} \mathrm{NMR}$ (126 MHz, chloroform-d, $\left.23^{\circ} \mathrm{C}\right): \delta 148.2,132.3,129.5,119.3,109.7,62.0,34.0,32.5,26.1$, 18.4, -5.2. IR (neat, $\mathrm{cm}^{-1}$ ): 2952, 2928, 2856, 2227, 1608, 1471, 1252, 1097, 832, 774. HRMS (ESI-TOF) m/z: [M+H] $]^{+}$Calcd for $\mathrm{C}_{16} \mathrm{H}_{26} \mathrm{NOSi}^{+} 276.1778$; Found 276.1777.

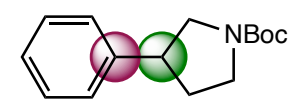

3s

tert-butyl 3-phenylpyrrolidine-1-carboxylate (3s). General procedure B was employed using 1a and 2s. Purification of the crude mixture by column chromatography (hexanes/ethyl acetate as eluent) afforded a clear oil that was dissolved in ethyl acetate, washed with $2 \mathrm{M} \mathrm{NaOH}$, dried over sodium sulfate, and concentrated to give $26 \mathrm{mg}$ (42\% yield) of a clear oil identified as 3 s. 
The ${ }^{1} \mathrm{H}$ NMR data is consistent with literature ${ }^{22}$ reported data. ${ }^{1} \mathrm{H}$ NMR $(500 \mathrm{MHz}$, chloroform- $d$, $\left.23^{\circ} \mathrm{C}\right): \delta 7.36-7.29(\mathrm{~m}, 2 \mathrm{H}), 7.27-7.21(\mathrm{~m}, 3 \mathrm{H}), 3.90-3.81(\mathrm{~m}, 0.5 \mathrm{H}), 3.81-3.74(\mathrm{~m}, 0.5 \mathrm{H})$, $3.70-3.60(\mathrm{~m}, 0.5 \mathrm{H}), 3.59-3.50(\mathrm{~m}, 0.5 \mathrm{H}), 3.46-3.23(\mathrm{~m}, 3 \mathrm{H}), 2.30-2.21(\mathrm{~m}, 1 \mathrm{H}), 2.04-$ $1.93(\mathrm{~m}, 1 \mathrm{H}), 1.50-1.44(\mathrm{~m}, 9 \mathrm{H})$.

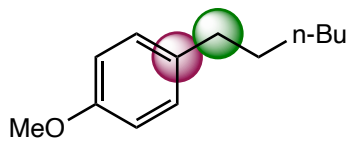

10

1-hexyl-4-methoxybenzene (10). Although 10 is not an entry in Scheme 2, the Co-catalyzed Suzuki-Miyaura coupling procedure to make it is reported here because $\mathbf{1 0}$ is one of the products formed from competition experiments in Scheme 4. General procedure B was employed using 9 and $2 \mathrm{~h}$. The yield of 10 was measured to be $42 \%$ by ${ }^{1} \mathrm{H}$ NMR of the crude reaction mixture using mesitylene as an internal standard. Purification of the crude mixture by column chromatography (hexanes/ethyl acetate as eluent) afforded a clear oil identified as an analytically pure sample of 10 . The ${ }^{1} \mathrm{H}$ NMR data is consistent with literature ${ }^{23}$ reported data. ${ }^{1} \mathbf{H}$ NMR (300 MHz, chloroform- $\left.d, 23^{\circ} \mathrm{C}\right): \delta 7.15-7.04(\mathrm{~m}, 2 \mathrm{H}), 6.88-6.77(\mathrm{~m}, 2 \mathrm{H}), 3.79(\mathrm{~s}, 3 \mathrm{H})$, $2.54(\mathrm{dd}, J=8.7,6.7 \mathrm{~Hz}, 2 \mathrm{H}), 1.66-1.52(\mathrm{~m}, 2 \mathrm{H}), 1.40-1.23(\mathrm{~m}, 6 \mathrm{H}), 0.93-0.82(\mathrm{~m}, 3 \mathrm{H})$.

\section{Radical Trap Experiments (Scheme 3)}

\section{Hexenyl radical clock (Scheme 3a)}

General procedure B with 4 and $\mathbf{5}$ was set up and carried out normally, with a modified workup procedure. After stirring for $18 \mathrm{~h}$ at $60^{\circ} \mathrm{C}$, dodecane $(57 \mu \mathrm{L}, 0.25 \mathrm{mmol})$ was added to the crude reaction mixture, which was diluted to approximately $5 \mathrm{~mL}$ with ethyl acetate. After adequate mixing, an approximately $0.5 \mathrm{~mL}$ aliquot of the resulting solution was removed and passed over a silica gel pipette column using ether as the eluent. The pipette column was 
flushed with ether until approximately $5 \mathrm{~mL}$ of eluent accumulated, and the resulting solution was analyzed directly by GC-FID (see Figures S3-S5 below).

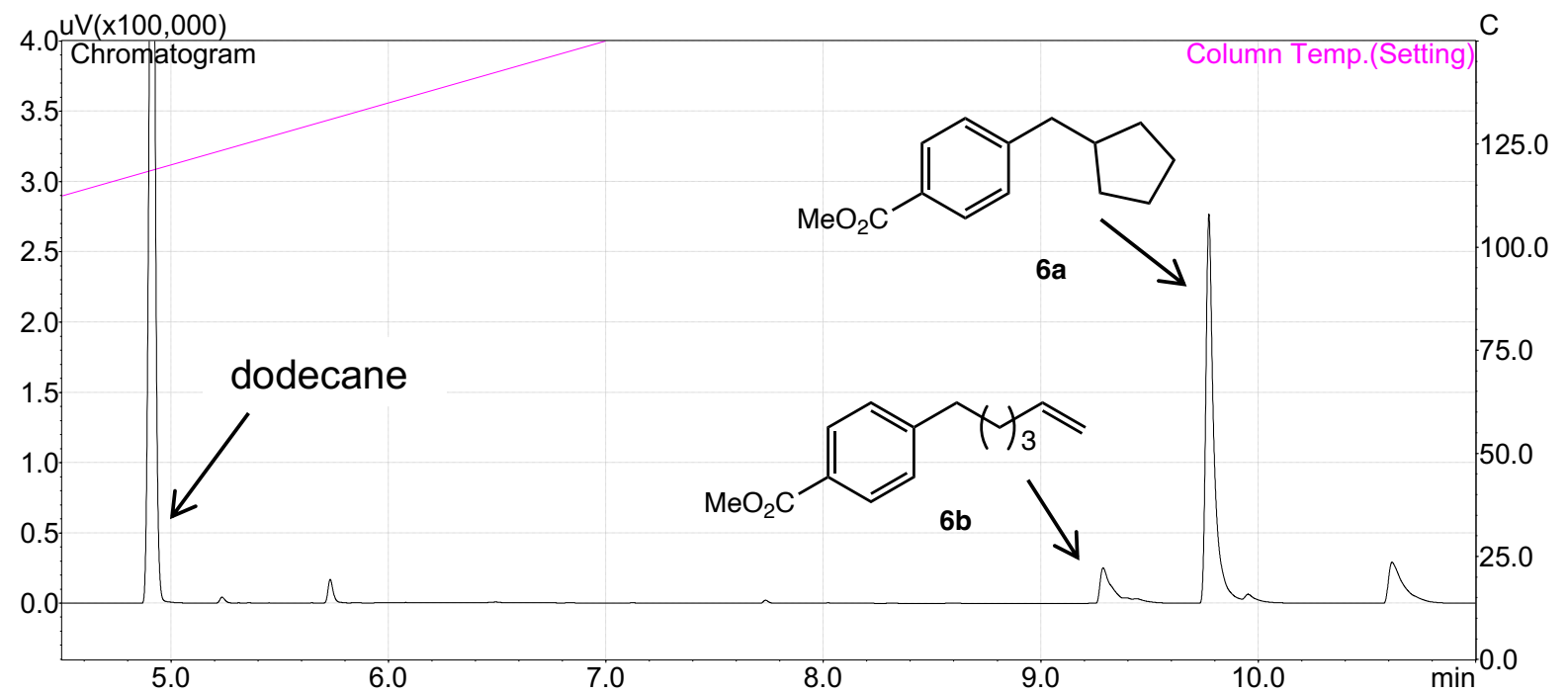

Figure S3. GC-FID analysis of the crude reaction mixture for Suzuki coupling of 4 and $\mathbf{5 .}$

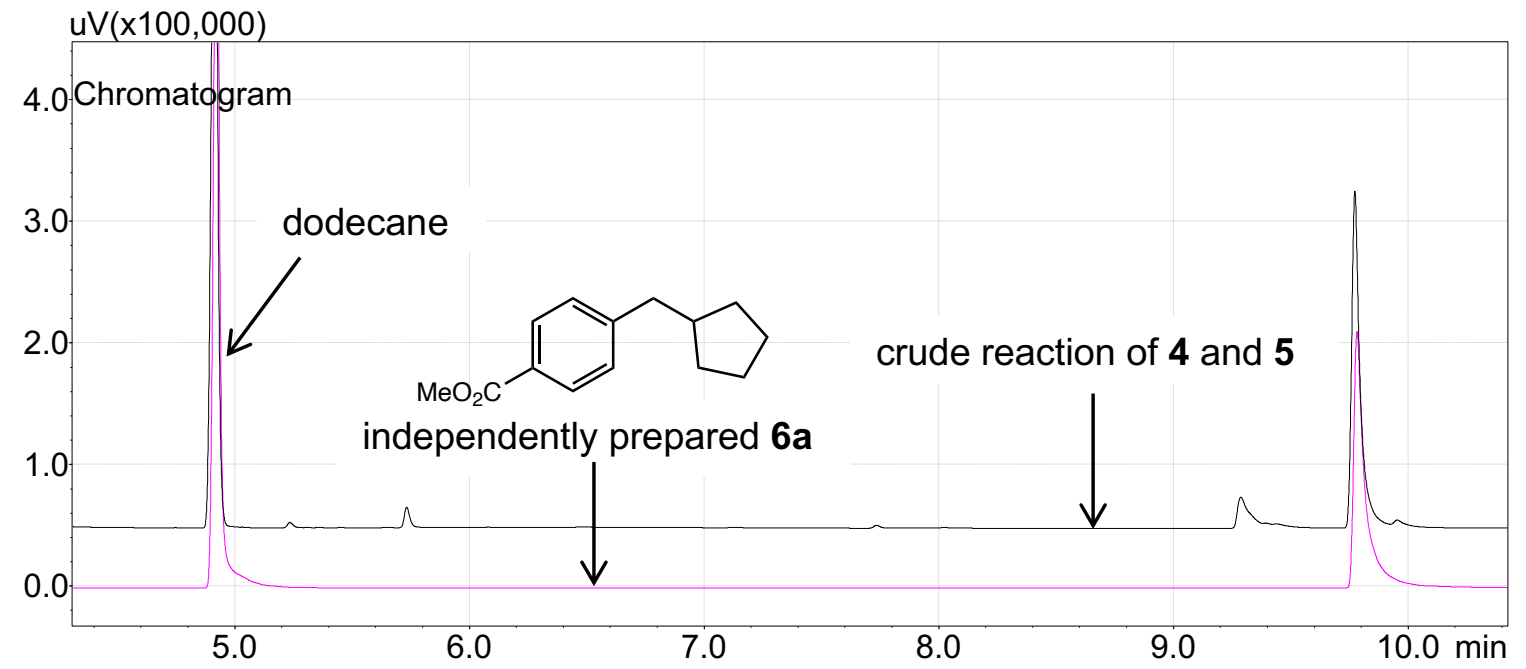

Figure S4. GC-FID chromatograms comparing the crude reaction mixture for Suzuki coupling of 4 and 5 (black line) with independently prepared 6 a (pink line). 


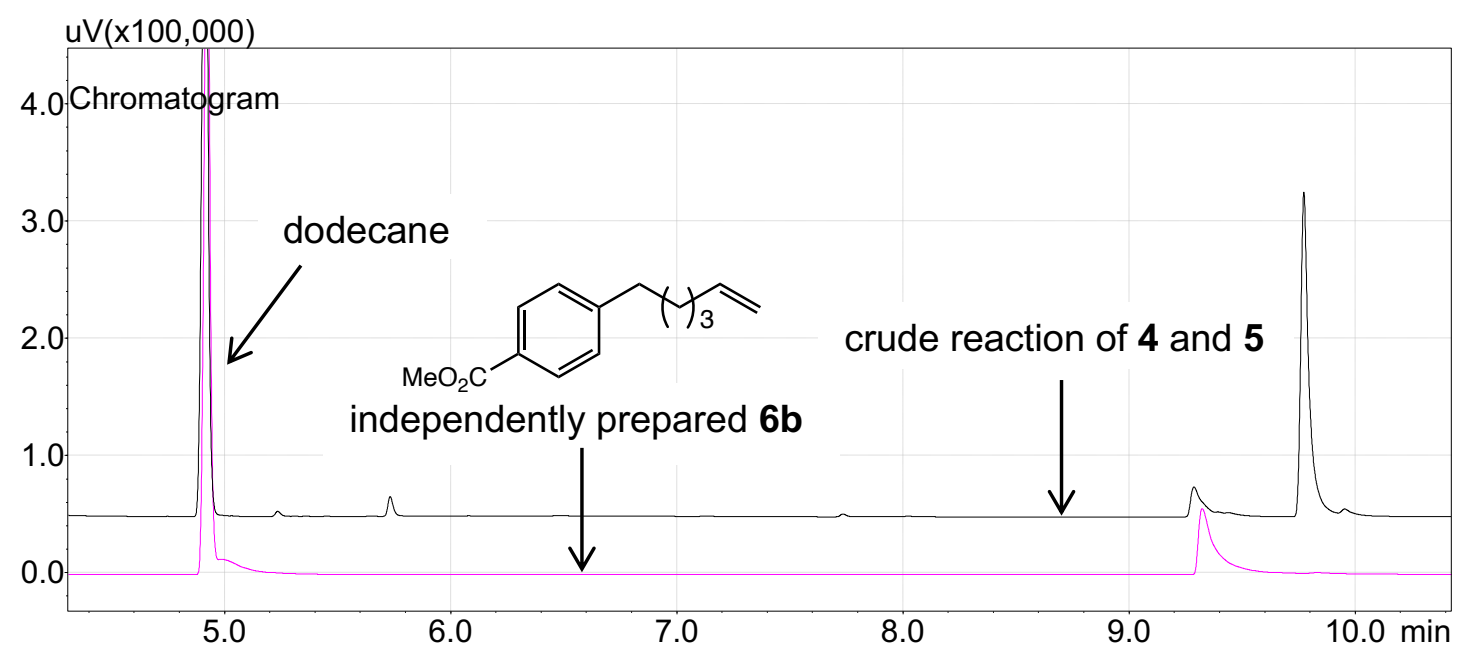

Figure S5. GC-FID chromatograms comparing the crude reaction mixture for Suzuki coupling of 4 and 5 (black line) with independently prepared 6b (pink line).

The leftover reaction volume $(\sim 4.5 \mathrm{~mL})$ was diluted with water and additional ethyl acetate. The layers were separated, and the aqueous layer was further extracted with ethyl acetate (x2). The combined organics were washed with brine, dried over sodium sulfate and concentrated. The resulting crude reaction mixture was then analyzed by ${ }^{1} \mathrm{H}$ NMR using mesitylene as an internal standard.

\section{Intermolecular radical trap (Scheme 3b)}

In an $\mathrm{N}_{2}$-filled glovebox, a $20 \mathrm{~mL}$ screw-capped scintillation vial equipped with a magnetic stir bar was charged with KOMe (22 mg, $0.31 \mathrm{mmol}),(\mathrm{DMCyDA}) \mathrm{CoBr}_{2}(13.5 \mathrm{mg}, 0.038 \mathrm{mmol})$, $\mathrm{PhB}(\mathrm{neo})(71 \mathrm{mg}, 0.375 \mathrm{mmol})$, and a solution of 1,1-diphenylethylene (66 $\mu \mathrm{L}, 0.375 \mathrm{mmol}$ ) DMA $(1.5 \mathrm{~mL})$. This mixture was allowed to stir for 5 minutes at room temperature before additional DMA (1 mL) and 1-bromo-2-methylpropane (2i, $27 \mu \mathrm{L}, 0.25 \mathrm{mmol})$ were added. The vial was capped, sealed with electrical tape, brought out of the glovebox, and placed in a preheated metal block set to $60^{\circ} \mathrm{C}$. After stirring at this temperature for $18 \mathrm{~h}$, the reaction was allowed to cool to room temperature, followed by subsequent addition of dodecane $(57 \mu \mathrm{L}, 0.25$ 
$\mathrm{mmol}$ ) and dilution with ethyl acetate to $5 \mathrm{~mL}$ using a volumetric flask. After adequate mixing, $0.5 \mathrm{~mL}\left(1 / 10^{\text {th }}\right.$ of the reaction mixture) was removed and passed over a silica gel pipette column using ether as the eluent. The pipette column was flushed with ether until approximately $5 \mathrm{~mL}$ of eluent accumulated, and the yield of isobutylbenzene $7 \mathrm{a}$ was measured to be $14 \%$ through direct analysis of this solution by GC-FID. The leftover reaction volume $(4.5 \mathrm{~mL}, 90 \%$ of the total reaction volume) was diluted with water and additional ethyl acetate. The layers were separated, and the aqueous layer was further extracted with ethyl acetate (x2). The combined organics were washed with brine, dried over sodium sulfate and concentrated. The resulting crude reaction mixture was then analyzed by ${ }^{1} \mathrm{H}$ NMR using mesitylene as an internal standard, where radical trap products $\mathbf{7 b}$ (18\% yield) and 7c $(7 \%$ yield) were observed (see Figures S6 \& S7 below).

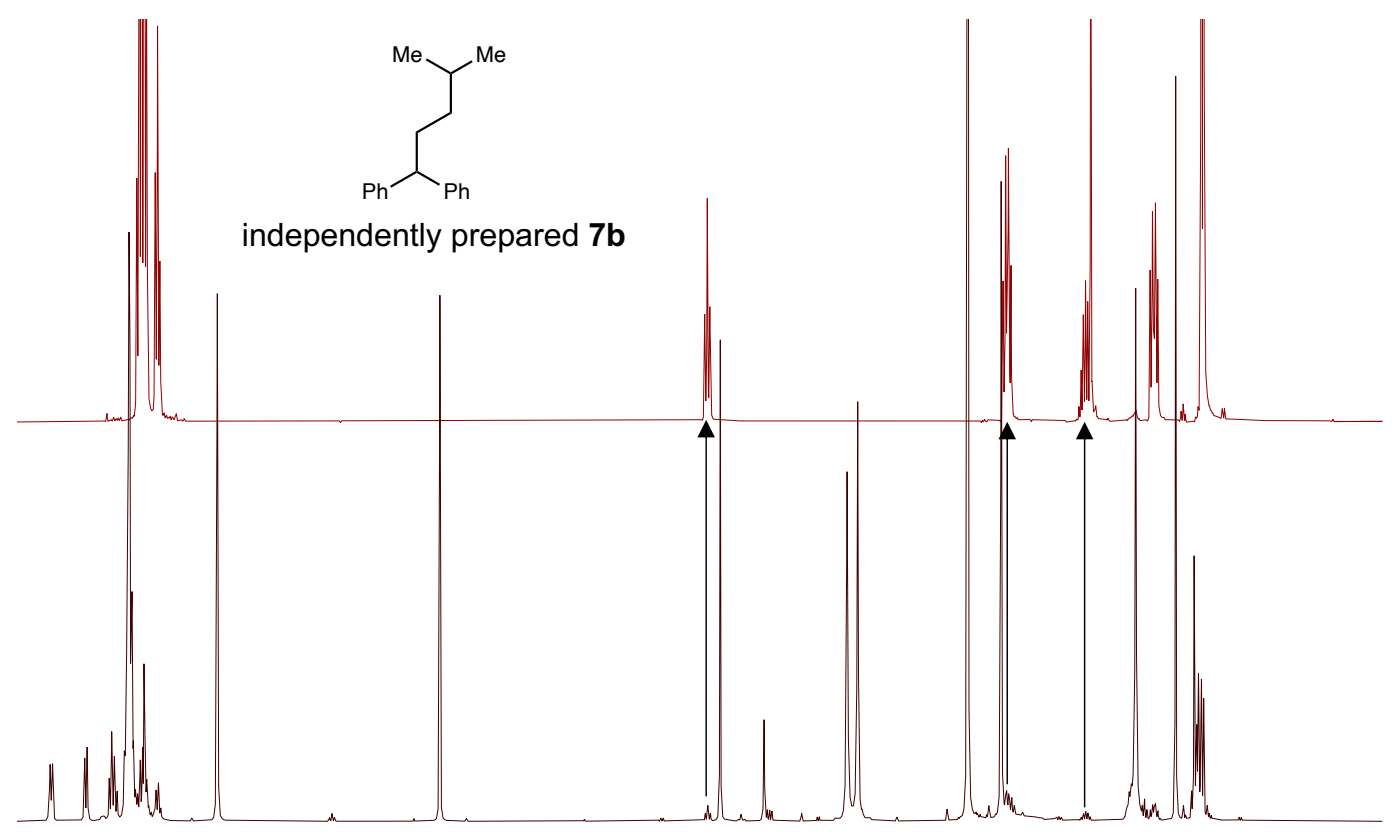

crude ${ }^{1} \mathrm{H}$ NMR of Suzuki coupling between $\mathrm{PhB}($ neo), $\mathrm{iBuBr}$, and 1,1-diphenylethylene

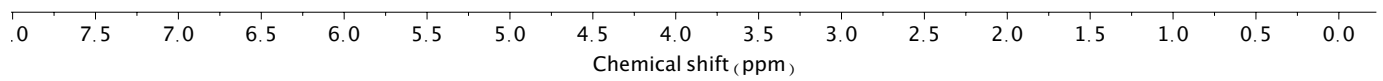

Figure S6. ${ }^{1} \mathrm{H}$ NMR comparison in $\mathrm{CDCl}_{3}$ of the crude intermolecular radical trap experiment (bottom) with independently prepared $\mathbf{7 b}$ (top). 


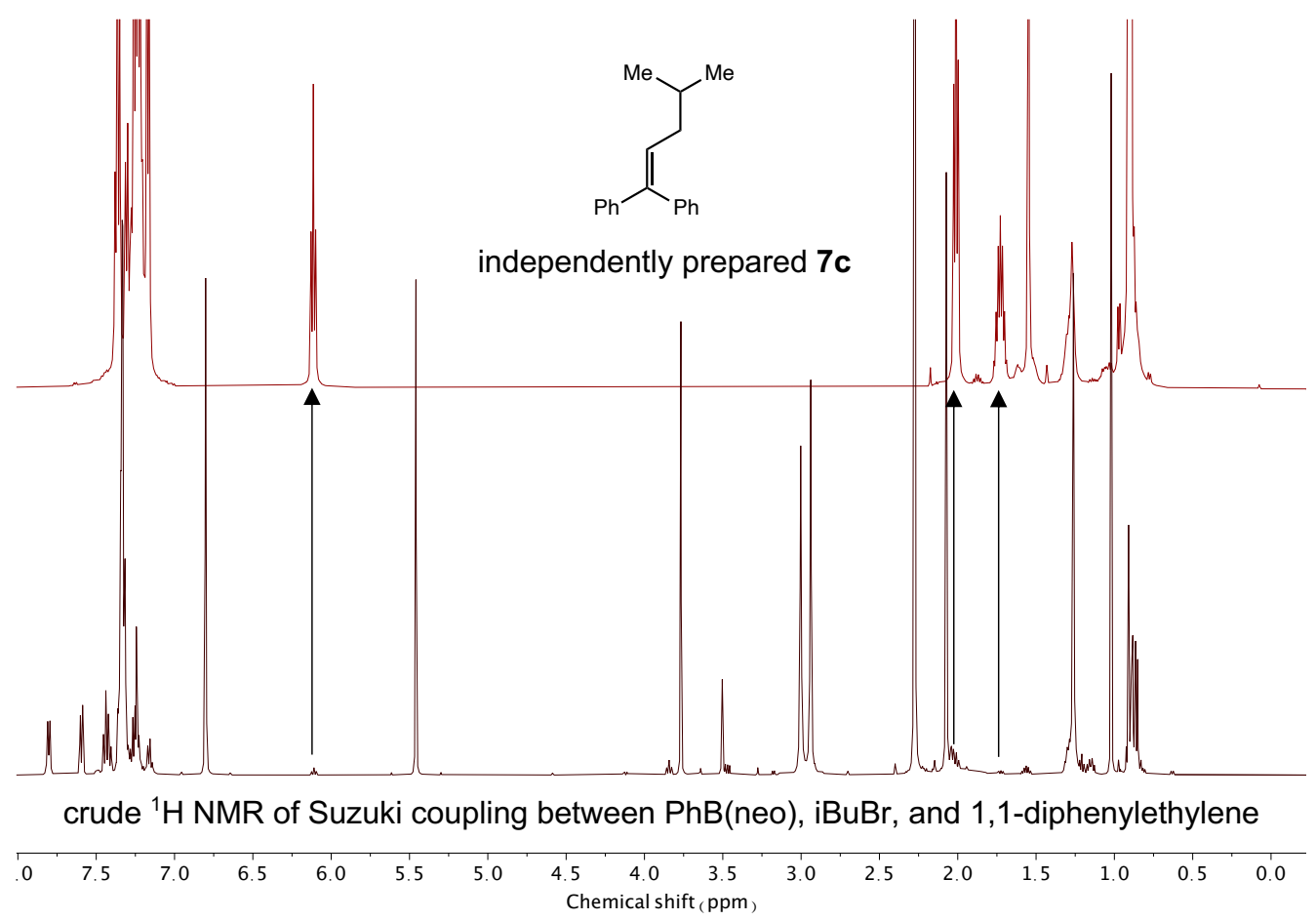

Figure S7. ${ }^{1} \mathrm{H}$ NMR comparison in $\mathrm{CDCl}_{3}$ of the crude intermolecular radical trap experiment (bottom) with independently prepared 7c (top).

\section{Borate Synthesis and Reactivity (Scheme 4) Synthesis of potassium aryl borates}

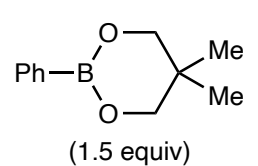

(1.5 equiv)

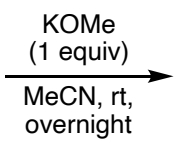

overnight

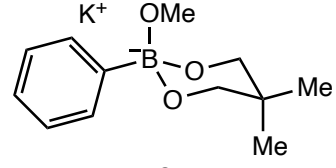

$8 \mathbf{a}$

potassium 2-methoxy-5,5-dimethyl-2-phenyl-1,3,2-dioxaborinan-2-uide (8a). In an $\mathrm{N}_{2}$-filled glovebox, a $20 \mathrm{~mL}$ scintillation vial equipped with a magnetic stir bar was charged with KOMe (70 mg, $1.0 \mathrm{mmol})$ and $\mathrm{PhB}(\mathrm{neo})(285 \mathrm{mg}, 1.5 \mathrm{mmol})$. Acetonitrile $(6 \mathrm{~mL})$ was added to the solid mixture, and the resulting suspension was allowed to stir overnight at room temperature. The next day, the reaction was filtered over celite, washed with acetonitrile, and concentrated under 
reduced pressure. Ether was added to the dried filtrate, and the resulting suspension was concentrated under reduced pressure. The resulting white solid was suspended in ether, filtered on a frit, and the collected precipitate was sequentially washed with ether and pentane to yield $120 \mathrm{mg}$ (46\% yield) of a white solid identified as potassium aryl borate salt $8 \mathbf{8}$. ${ }^{1} \mathbf{H}$ NMR (500 MHz, DMSO-d $\left.d_{6}, 23^{\circ} \mathrm{C}\right): \delta 7.36-7.30(\mathrm{~m}, 2 \mathrm{H}), 6.99(\mathrm{t}, J=7.4 \mathrm{~Hz}, 2 \mathrm{H}), 6.92-6.85(\mathrm{~m}, 1 \mathrm{H}), 3.31$ $(\mathrm{d}, J=9.6 \mathrm{~Hz}, 2 \mathrm{H}), 2.99(\mathrm{~d}, J=9.5 \mathrm{~Hz}, 2 \mathrm{H}), 2.90(\mathrm{~s}, 3 \mathrm{H}), 0.75(\mathrm{~s}, 3 \mathrm{H}), 0.73(\mathrm{~s}, 3 \mathrm{H}) .{ }^{13} \mathrm{C}\left\{{ }^{1} \mathrm{H}\right\}$ NMR (126 MHz, DMSO- $\left.d_{6}, 23^{\circ} \mathrm{C}\right)$ : (note: one aromatic carbon signal not observed, likely the carbon attached to boron) $\delta 132.8,125.6,123.4,71.5,48.7,32.4,23.5,23.3 .{ }^{11} \mathrm{~B}$ NMR (96 $\left.\mathrm{MHz}, \mathrm{DMSO}-d_{6}, 23^{\circ} \mathrm{C}\right): \delta 2.60$. IR (neat, $\left.\mathrm{cm}^{-1}\right): 3001,2948,2883,2847,1358,1080,1032,956$, $883,745,704,675$.
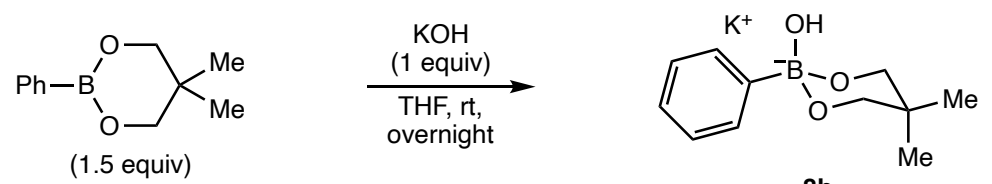

8b

potassium 2-hydroxy-5,5-dimethyl-2-phenyl-1,3,2-dioxaborinan-2-uide (8b). In an $\mathrm{N}_{2}$-filled glovebox, a $20 \mathrm{~mL}$ scintillation vial equipped with a magnetic stir bar was charged with $\mathrm{KOH}$ (132 $\mathrm{mg}, 2.0 \mathrm{mmol})$ and $\mathrm{PhB}(\mathrm{neo})(570 \mathrm{mg}, 3 \mathrm{mmol})$. THF $(10 \mathrm{~mL})$ was added to the solid mixture, and the resulting suspension was allowed to stir overnight at room temperature. The next day, the reaction was filtered over celite and washed with THF. Pentane was added the filtrate. The resulting precipitate was filtered, washed with pentane and dried under reduced pressure to yield $200 \mathrm{mg}$ ( $41 \%$ yield) of a white solid identified as potassium aryl borate salt $\mathbf{8 b}$. ${ }^{1} \mathrm{H}$ NMR $\left(500 \mathrm{MHz}, \mathrm{DMSO}-d_{6}, 23{ }^{\circ} \mathrm{C}\right): \delta \delta 7.41-7.31(\mathrm{~m}, 2 \mathrm{H}), 7.00(\mathrm{t}, J=7.3 \mathrm{~Hz}, 2 \mathrm{H}), 6.93-$ $6.86(\mathrm{~m}, 1 \mathrm{H}), 3.27(\mathrm{~d}, J=9.7 \mathrm{~Hz}, 2 \mathrm{H}), 3.05(\mathrm{~d}, J=9.7 \mathrm{~Hz}, 2 \mathrm{H}), 0.86(\mathrm{~s}, 3 \mathrm{H}), 0.61(\mathrm{~s}, 3 \mathrm{H})$. ${ }^{13} \mathrm{C}\left\{{ }^{1} \mathrm{H}\right\}$ NMR $\left(126 \mathrm{MHz}, \mathrm{DMSO}-d_{6}, 23{ }^{\circ} \mathrm{C}\right)$ : (note: one aromatic carbon signal not observed, likely the carbon attached to boron) $\delta 132.6,125.8,123.5,72.0,32.6,23.8,22.9 .{ }^{11} \mathrm{~B}$ NMR (96 
MHz, DMSO- $\left.d_{6}, 23^{\circ} \mathrm{C}\right): \delta 2.32$. IR (neat, $\left.\mathrm{cm}^{-1}\right): 3655,3058,2949,2876,2839,1471,1217$, $1165,1104,1038,971,957,910,893,756,707$.

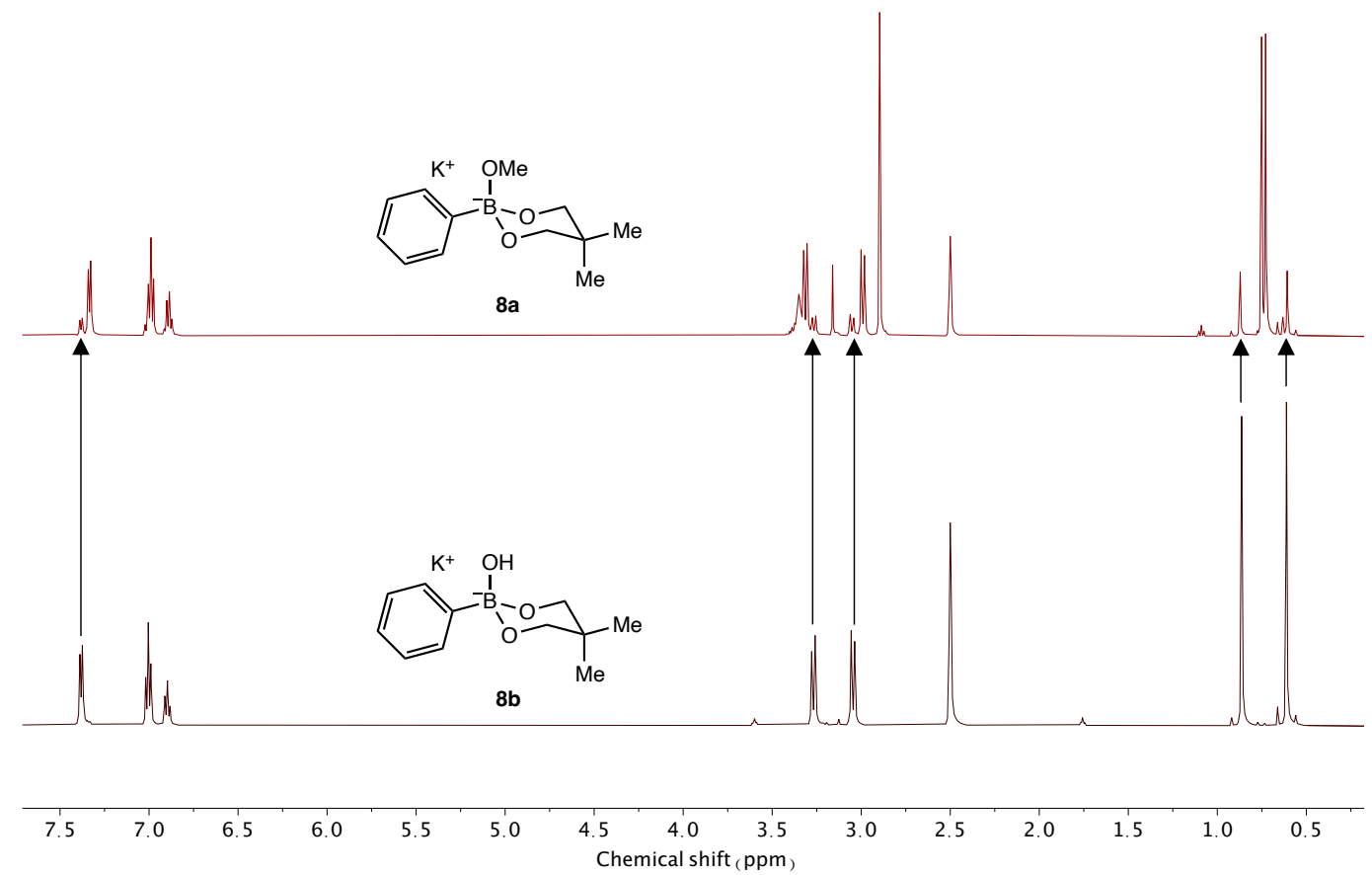

Figure S8. ${ }^{1} \mathrm{H}$ NMR comparison in DMSO- $d_{6}$ that shows hydroxy borate $\mathbf{8 b}$ (bottom) is a minor component in the ${ }^{1} \mathrm{H}$ NMR of methoxy borate $\mathbf{8 a}$ (top). Hydroxy borate $\mathbf{8 b}$ likely comes from deprotonation of water in the NMR solvent by methoxy borate $\mathbf{8 a}$. 


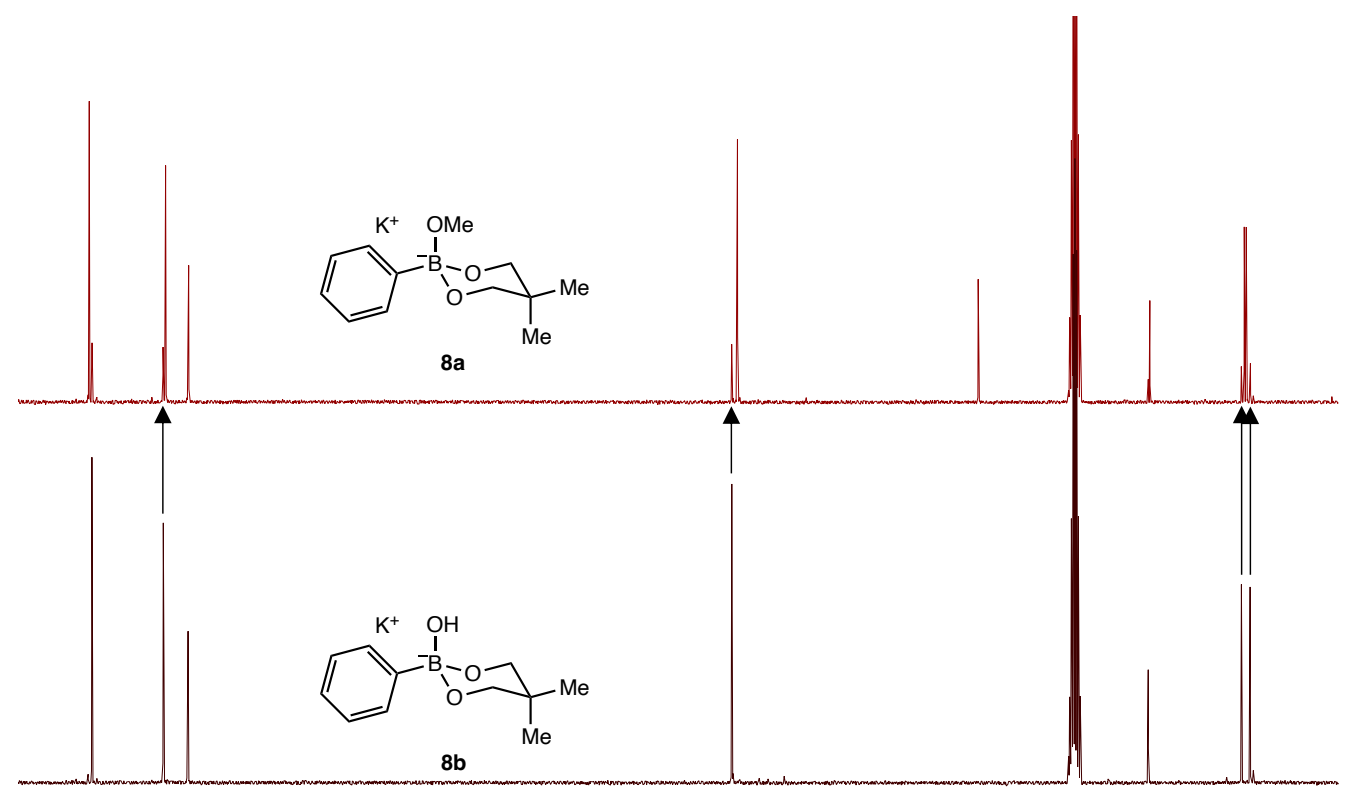

$\begin{array}{llllllllllllllllllllllllllllllll}135 & 130 & 125 & 120 & 115 & 110 & 105 & 100 & 95 & 90 & 85 & 80 & 75 & 70 & 65 & 60 & 55 & 50 & 45 & 40 & 35 & 30 & 25 & 20 & 1 ! \\ \text { Chemical shift (ppm) }\end{array}$

Figure S9. ${ }^{13} \mathrm{C}$ NMR comparison in DMSO- $d_{6}$ that shows hydroxy borate $\mathbf{8 b}$ (bottom) is a minor component in the ${ }^{13} \mathrm{C}$ NMR of methoxy borate $\mathbf{8 a}$ (top). Hydroxy borate $\mathbf{8 b}$ likely comes from deprotonation of water in the NMR solvent by methoxy borate $\mathbf{8 a}$.

\section{Use of potassium aryl borates in Co-catalyzed Suzuki coupling}
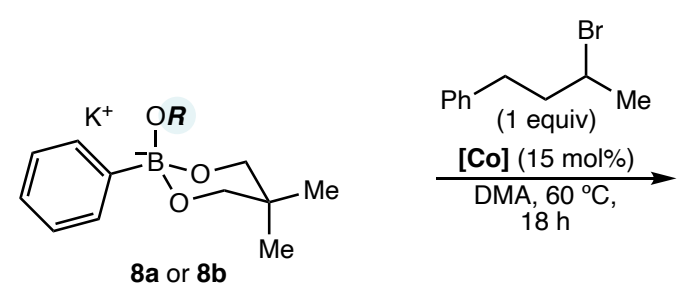

In an $\mathrm{N}_{2}$-filled glovebox, a $20 \mathrm{~mL}$ screw-capped scintillation vial equipped with a magnetic stir bar was charged with borate reagent $\mathbf{8 a}$ or $\mathbf{8 b}(0.375 \mathrm{mmol}),\left(\mathrm{DMCyDA} \mathrm{CoBr}_{2}(13.5 \mathrm{mg}\right.$, $0.038 \mathrm{mmol})$ and DMA $(1.5 \mathrm{~mL})$. This mixture was allowed to stir for 5 minutes at room temperature before (3-bromobutyl)benzene $(2 \mathbf{e}-\mathbf{g}, 53 \mathrm{mg}, 0.25 \mathrm{mmol}$ ) was added as a solution in DMA (1 mL). The vial was capped, sealed with electrical tape, brought out of the glovebox, 
and placed in a preheated metal block on a hotplate set to $60{ }^{\circ} \mathrm{C}$. After stirring at this temperature for $18 \mathrm{~h}$, the reaction was allowed to cool to room temperature, followed by subsequent dilution with ethyl acetate and water. The layers were separated, and the aqueous layer was extracted with ethyl acetate two more times. The combined organics were washed with brine, dried over sodium sulfate, and concentrated. When 8a was used, purification of the crude reaction mixture by column chromatography (hexanes as eluent) gave $26 \mathrm{mg}$ (49\% yield) of a clear oil that was identified as $\mathbf{3 e}$ (see section $\mathrm{V}$ for characterization data). When $\mathbf{8 b}$ was used, only trace quantities of $\mathbf{3 e}$ were observed by GC-MS analysis of the crude reaction mixture. 


\section{References}

1. Pangborn, A. B.; Giardello, M. A.; Grubbs, R. H.; Rosen, R. K.; Timmers, F. J. Safe and Convenient Procedure for Solvent Purification. Organometallics 1996, 15, 1518-152.

2. Peacock, D. M.; Roos, C. B.; Hartwig, J. F. Palladium-Catalyzed Cross Coupling of Secondary and Tertiary Alkyl Bromides with a Nitrogen Nucleophile. ACS Cent. Sci. 2016, 2, 647-652.

3. Wang, J.; Hanan, G. S. A Facile Route to Sterically Hindered and Non-Hindered 4'-Aryl2,2':6',2"-Terpyridines. Synlett 2005, 1251-1254.

4. Semproni, S. P.; Atienza, C. C. H.; Chirik, P. J. Oxidative Addition and C-H Activation Chemistry with a PNP Pincer-Ligated Cobalt Complex. Chem. Sci. 2014, 5, 1956-1960.

5. Merchant, R. R.; Lopez, J. A. A General C(Sp3)-C(Sp3) Cross-Coupling of Benzyl Sulfonylhydrazones with Alkyl Boronic Acids. Org. Lett. 2020, 22, 2271-2275.

6. Fürstner, A.; Leitner, A.; Méndez, M.; Krause, H. Iron-Catalyzed Cross-Coupling Reactions. J. Am. Chem. Soc. 2002, 124, 13856-13863.

7. Tobisu, M.; Zhao, J.; Kinuta, H.; Furukawa, T.; Igarashi, T.; Chatani, N. Nickel-Catalyzed Borylation of Aryl and Benzyl 2-Pyridyl Ethers: A Method for Converting a Robust OrthoDirecting Group. Adv. Synth. Catal. 2016, 358, 2417-2421.

8. Wilson, D. A.; Wilson, C. J.; Moldoveanu, C.; Resmerita, A.-M.; Corcoran, P.; Hoang, L. M.; Rosen, B. M.; Percec, V. Neopentylglycolborylation of Aryl Mesylates and Tosylates Catalyzed by Ni-Based Mixed-Ligand Systems Activated with Zn. J. Am. Chem. Soc. 2010, 132, 1800-1801.

9. Shi, B.; Boyle, R. W. Synthesis of Unsymmetrically Substituted Meso-Phenylporphyrins by Suzuki Cross Coupling Reactions. J. Chem. Soc., Perkin Trans. 1 2002, 1397-1400.

10. Podichetty, A. K.; Faust, A.; Kopka, K.; Wagner, S.; Schober, O.; Schäfers, M.; Haufe, G. Fluorinated Isatin Derivatives. Part 1: Synthesis of New N-Substituted (S)-5-[1-(2Methoxymethylpyrrolidinyl)Sulfonyl]Isatins as Potent Caspase-3 and -7 Inhibitors. Bioorg. Med. Chem. 2009, 17, 2680-2688.

11. Zhou, Q.-Q.; Düsel, S. J. S.; Lu, L.-Q.; König, B.; Xiao, W.-J. Alkenylation of Unactivated Alkyl Bromides through Visible Light Photocatalysis. Chem. Commun. 2018, 55, 107-110.

12. Crockett, M. P.; Wong, A. S.; Li, B.; Byers, J. A. Rational Design of an Iron-Based Catalyst for Suzuki-Miyaura Cross-Couplings Involving Heteroaromatic Boronic Esters and Tertiary Alkyl Electrophiles. Angew. Chem. Int. Ed. 2020, 59, 5392-5397.

13. Ghorai, S. K.; Jin, M.; Hatakeyama, T.; Nakamura, M. Cross-Coupling of Non-Activated Chloroalkanes with Aryl Grignard Reagents in the Presence of Iron/N-Heterocyclic Carbene Catalysts. Org. Lett. 2012, 14, 1066-1069. 
14. Green, S. A.; Matos, J. L. M.; Yagi, A.; Shenvi, R. A. Branch-Selective Hydroarylation: lodoarene-Olefin Cross-Coupling. J. Am. Chem. Soc. 2016, 138, 12779-12782.

15. Bonet, A.; Odachowski, M.; Leonori, D.; Essafi, S.; Aggarwal, V. K. Enantiospecific Sp 2 Sp 3 Coupling of Secondary and Tertiary Boronic Esters. Nat. Chem. 2014, 6, 584-589.

16. Wolfe, J. P.; Singer, R. A.; Yang, B. H.; Buchwald, S. L. Highly Active Palladium Catalysts for Suzuki Coupling Reactions. J. Am. Chem. Soc. 1999, 121, 9550-9561.

17. Degani, I.; Dughera, S.; Fochi, R.; Gazzetto, S. Isomerization of Trimethyl a-Keto Trithioorthocarboxylates into $\alpha, \alpha-B i s(M e t h y l t h i o)$ Thiolcarboxylates. A New Rearrangement of Synthetic Interest. J. Org. Chem. 1997, 62, 7228-7233.

18. Phapale, V. B.; Guisán-Ceinos, M.; Buñuel, E.; Cárdenas, D. J. Nickel-Catalyzed CrossCoupling of Alkyl Zinc Halides for the Formation of $\mathrm{C}(\mathrm{Sp} 2)-\mathrm{C}(\mathrm{Sp} 3)$ Bonds: Scope and Mechanism. Chem. - Eur. J.I 2009, 15, 12681-12688.

19. Yan, X.-B.; Li, C.-L.; Jin, W.-J.; Guo, P.; Shu, X.-Z. Reductive Coupling of Benzyl Oxalates with Highly Functionalized Alkyl Bromides by Nickel Catalysis. Chem. Sci. 2018, 9, 45294534.

20. Patel, N. R.; Molander, G. A. Phenol Derivatives as Coupling Partners with Alkylsilicates in Photoredox/Nickel Dual Catalysis. J. Org. Chem. 2016, 81, 7271-7275.

21. Yang, Y.; Zhou, Q.; Cai, J.; Xue, T.; Liu, Y.; Jiang, Y.; Su, Y.; Chung, L.; Vicic, D. A. Exploiting the Trifluoroethyl Group as a Precatalyst Ligand in Nickel-Catalyzed SuzukiType Alkylations. Chem. Sci. 2019, 10, 5275-5282.

22. Barré, B.; Gonnard, L.; Campagne, R.; Reymond, S.; Marin, J.; Ciapetti, P.; Brellier, M.; Guérinot, A.; Cossy, J. Iron- and Cobalt-Catalyzed Arylation of Azetidines, Pyrrolidines, and Piperidines with Grignard Reagents. Org. Lett. 2014, 16, 6160-6163.

23. Ackermann, L.; Kapdi, A. R.; Schulzke, C. Air-Stable Secondary Phosphine Oxide or Chloride (Pre)Ligands for Cross-Couplings of Unactivated Alkyl Chlorides. Org. Lett. 2010, 12, 2298-2301. 
IX. NMR Spectra 


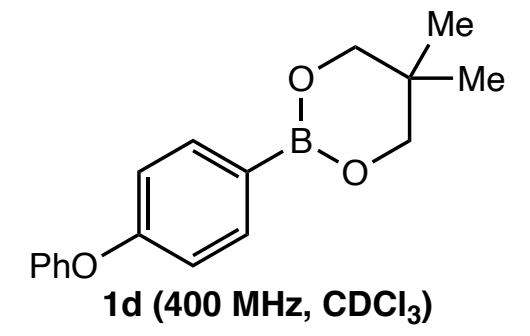

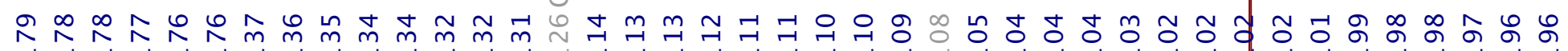

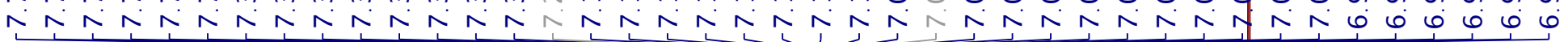

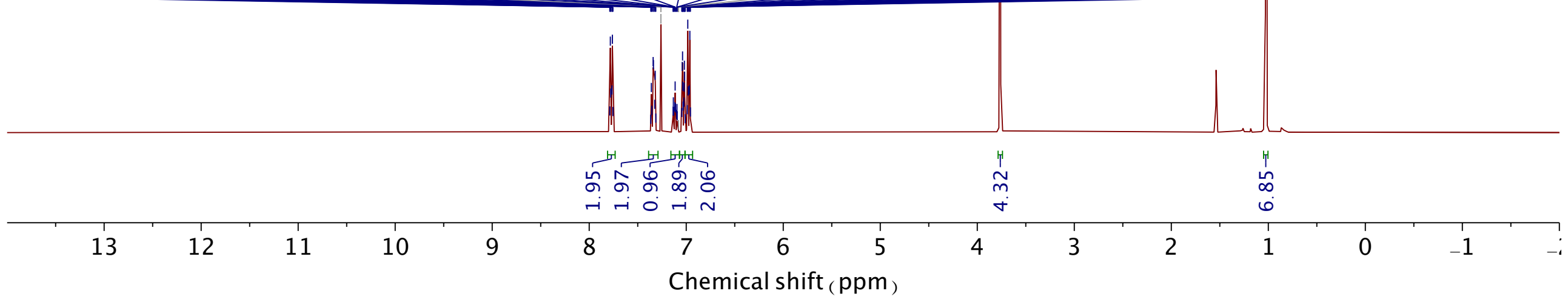




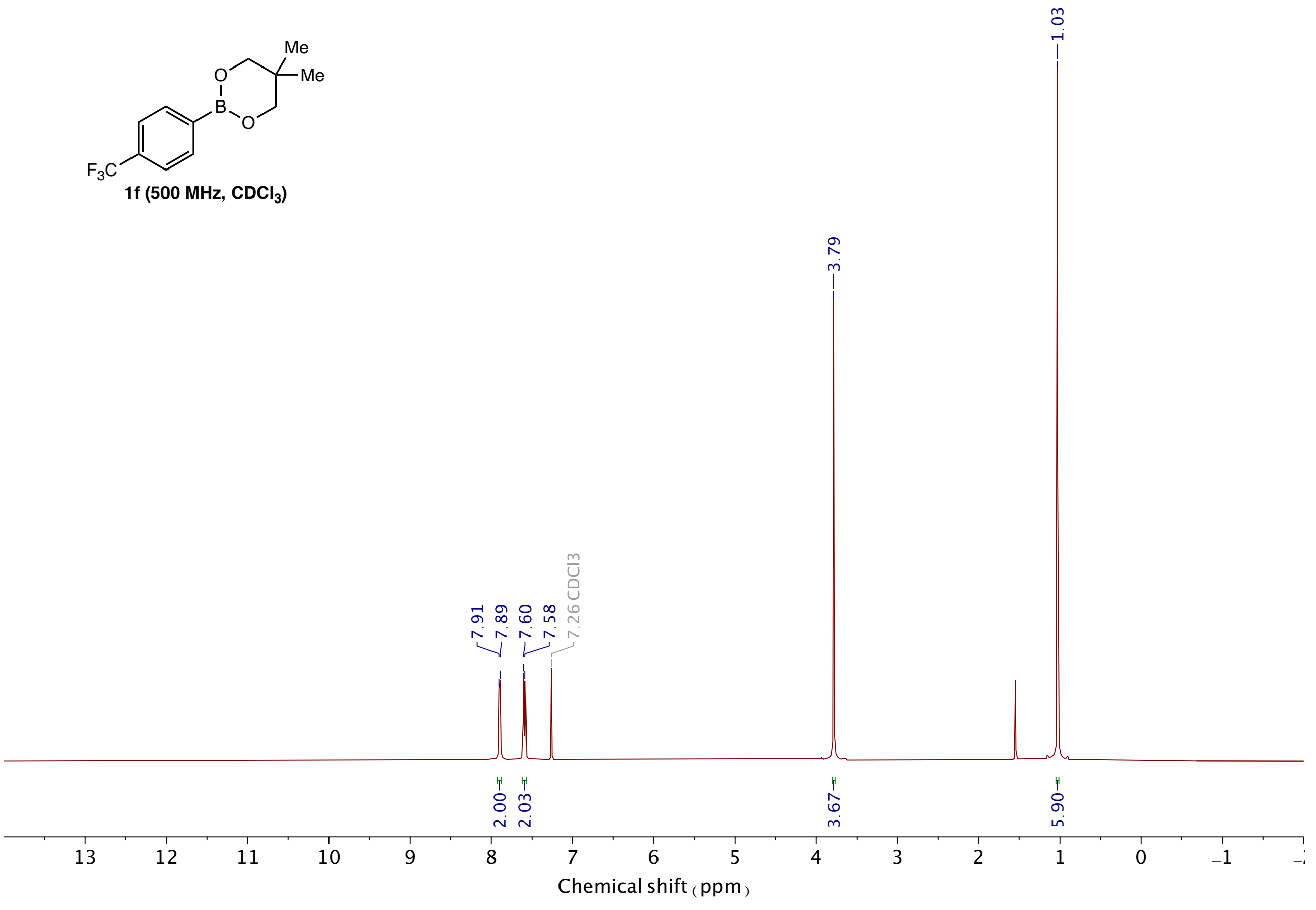


<smiles>[Y6]C1(C)COB(c2cccc(OC)c2)OC1</smiles>

$1 \mathrm{~g}\left(500 \mathrm{MHz}, \mathrm{CDCl}_{3}\right)$

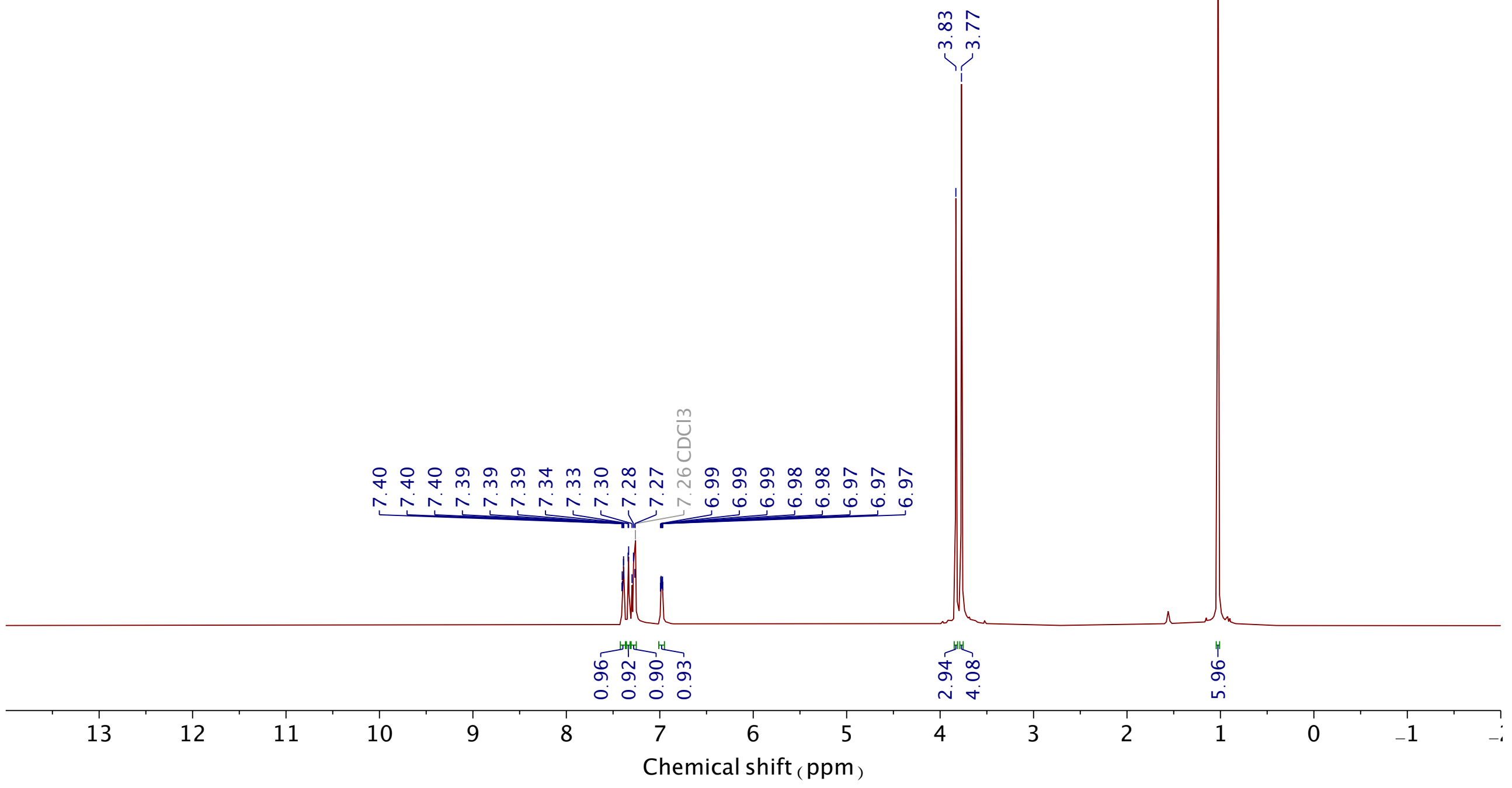




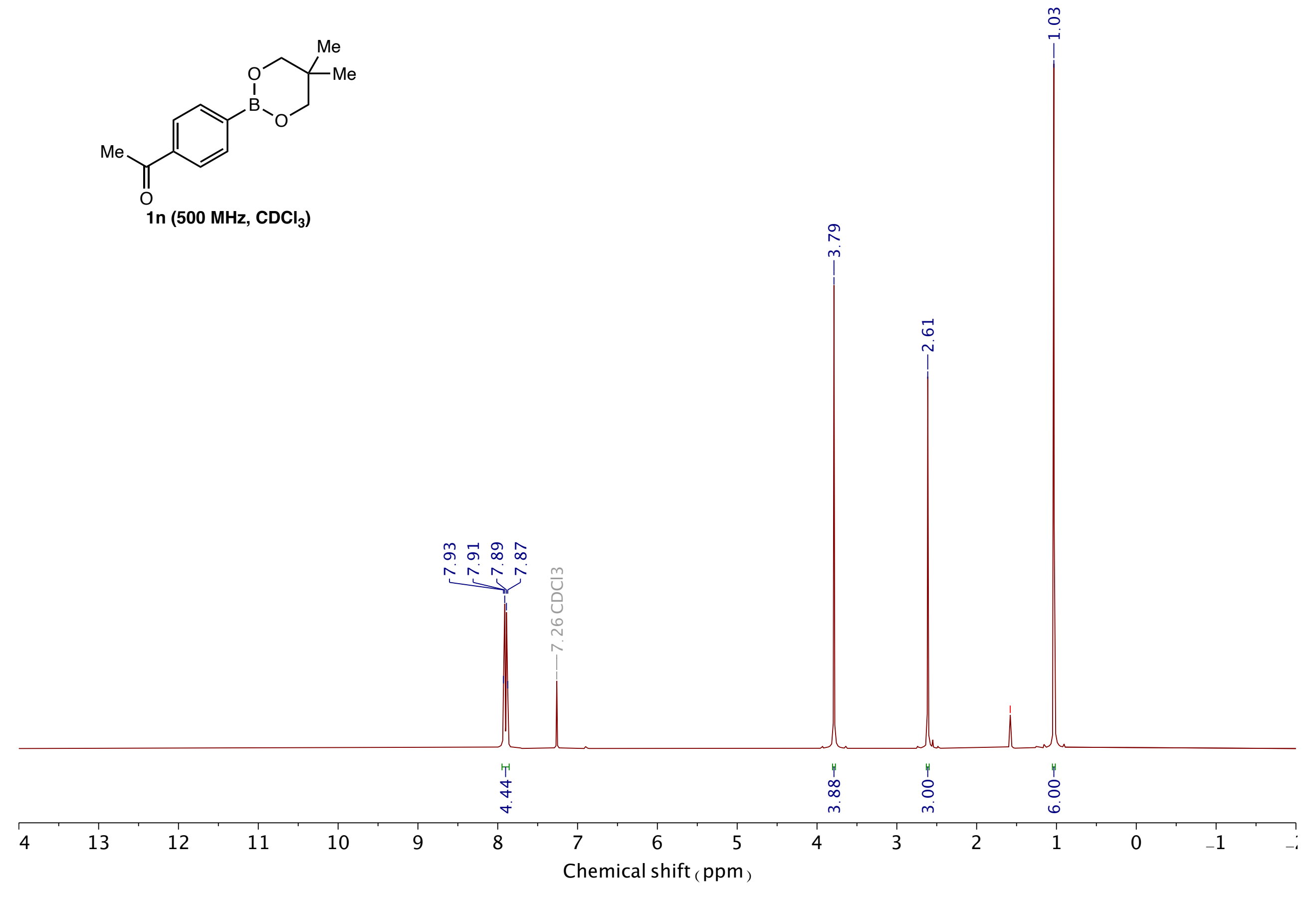



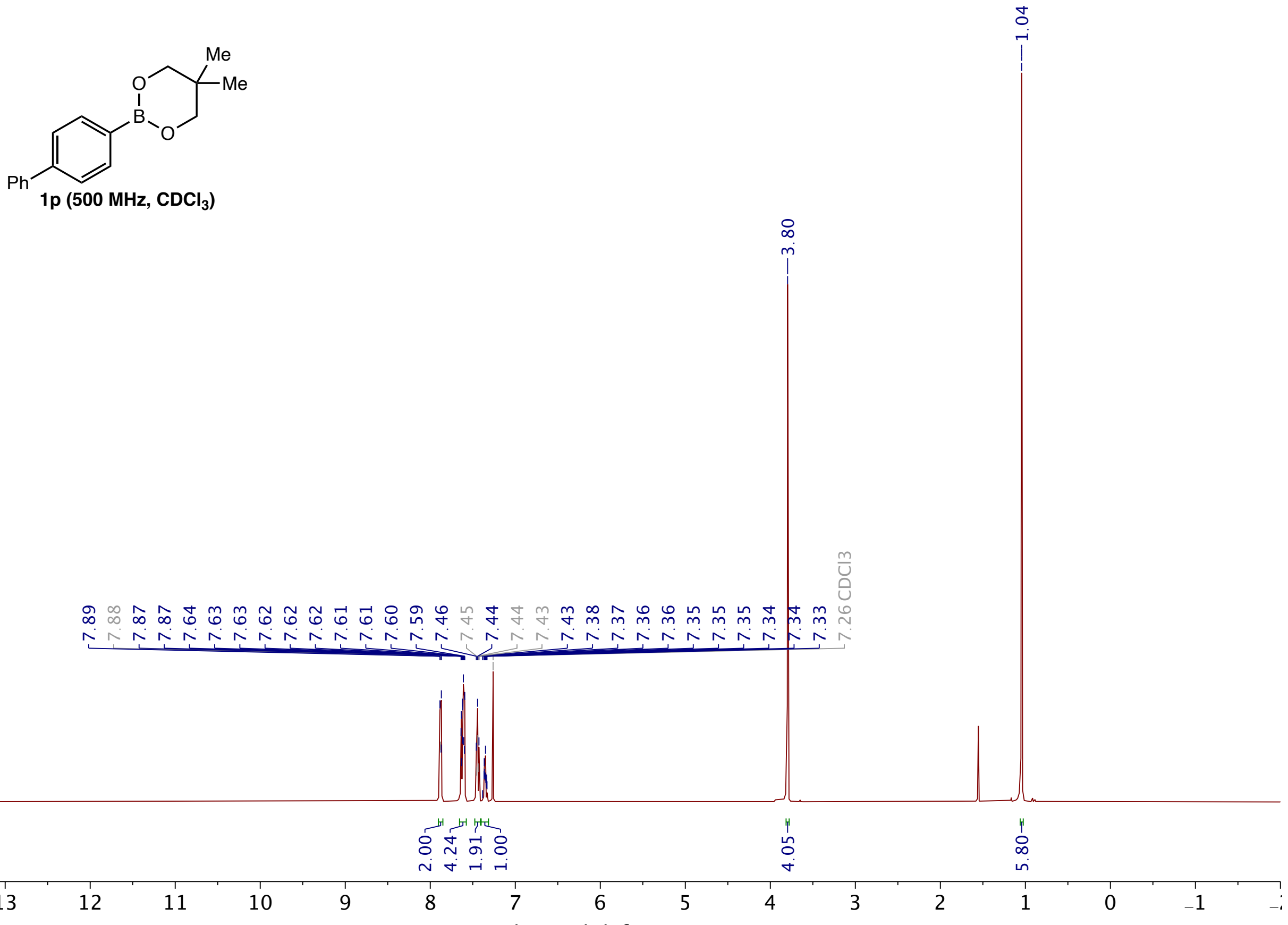

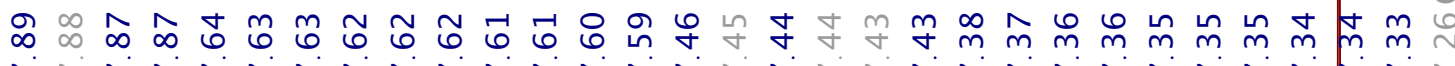

N N

$12 \quad 11$

10

9

Chemical shift (ppm) 

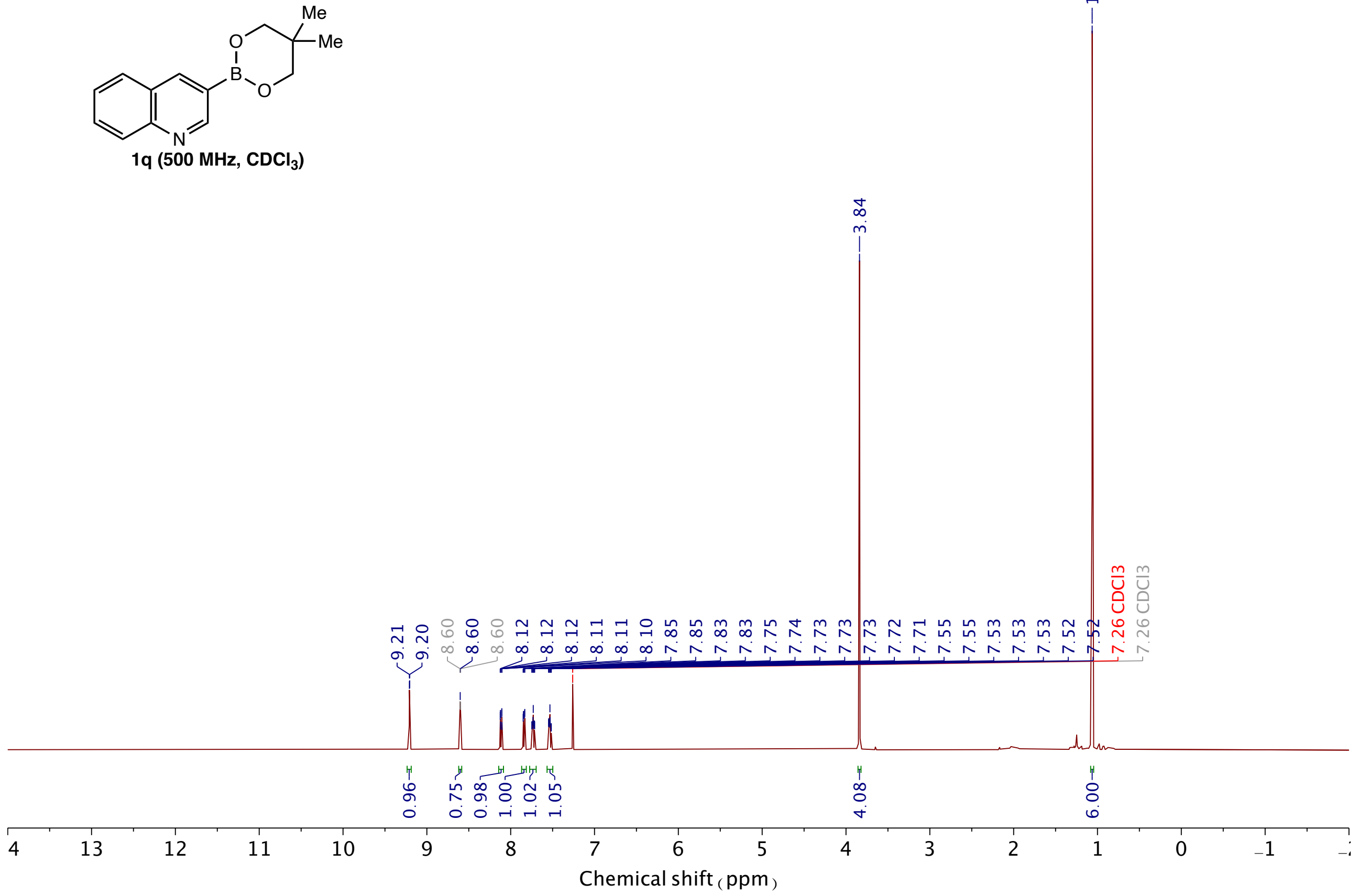

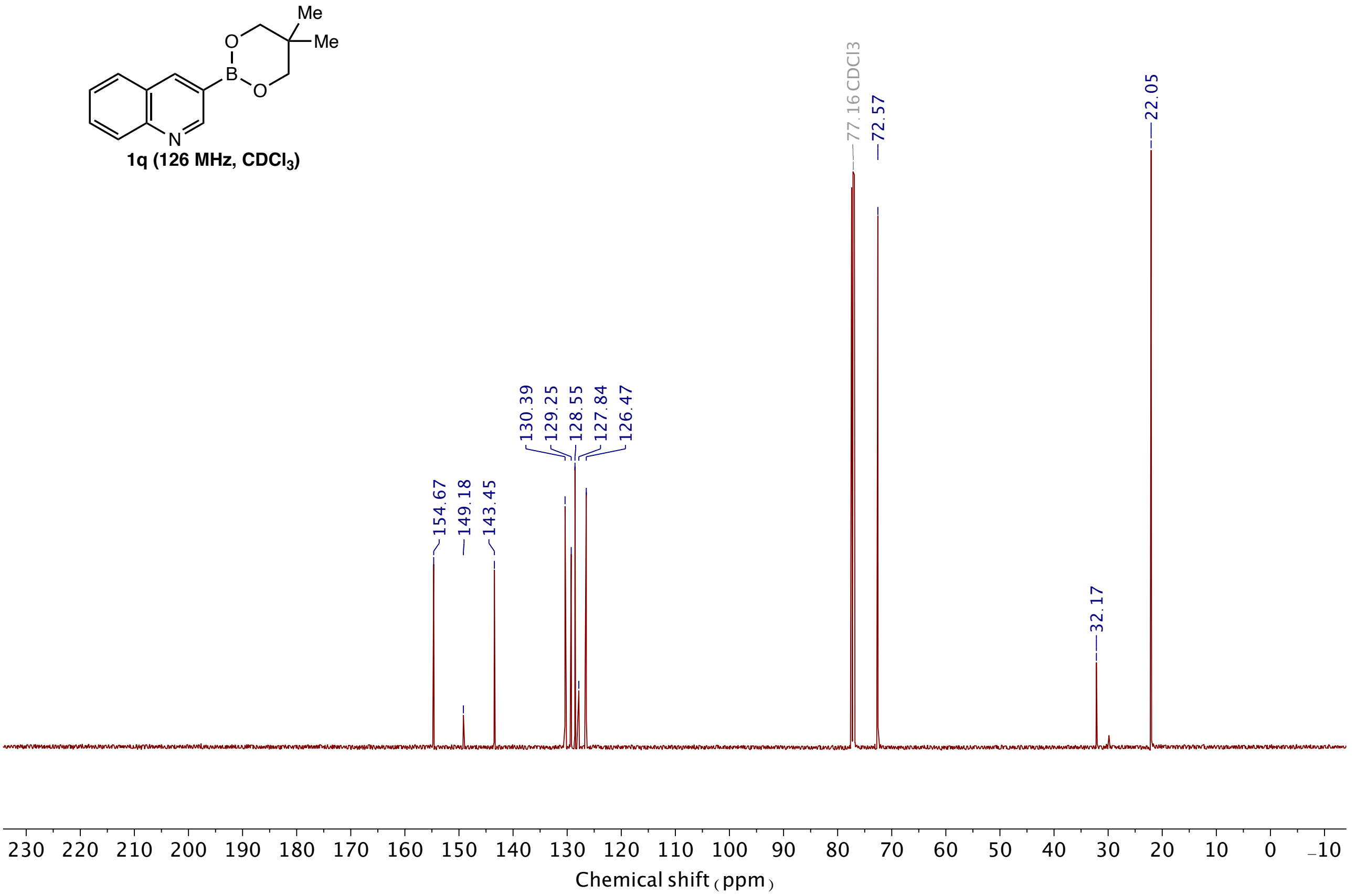

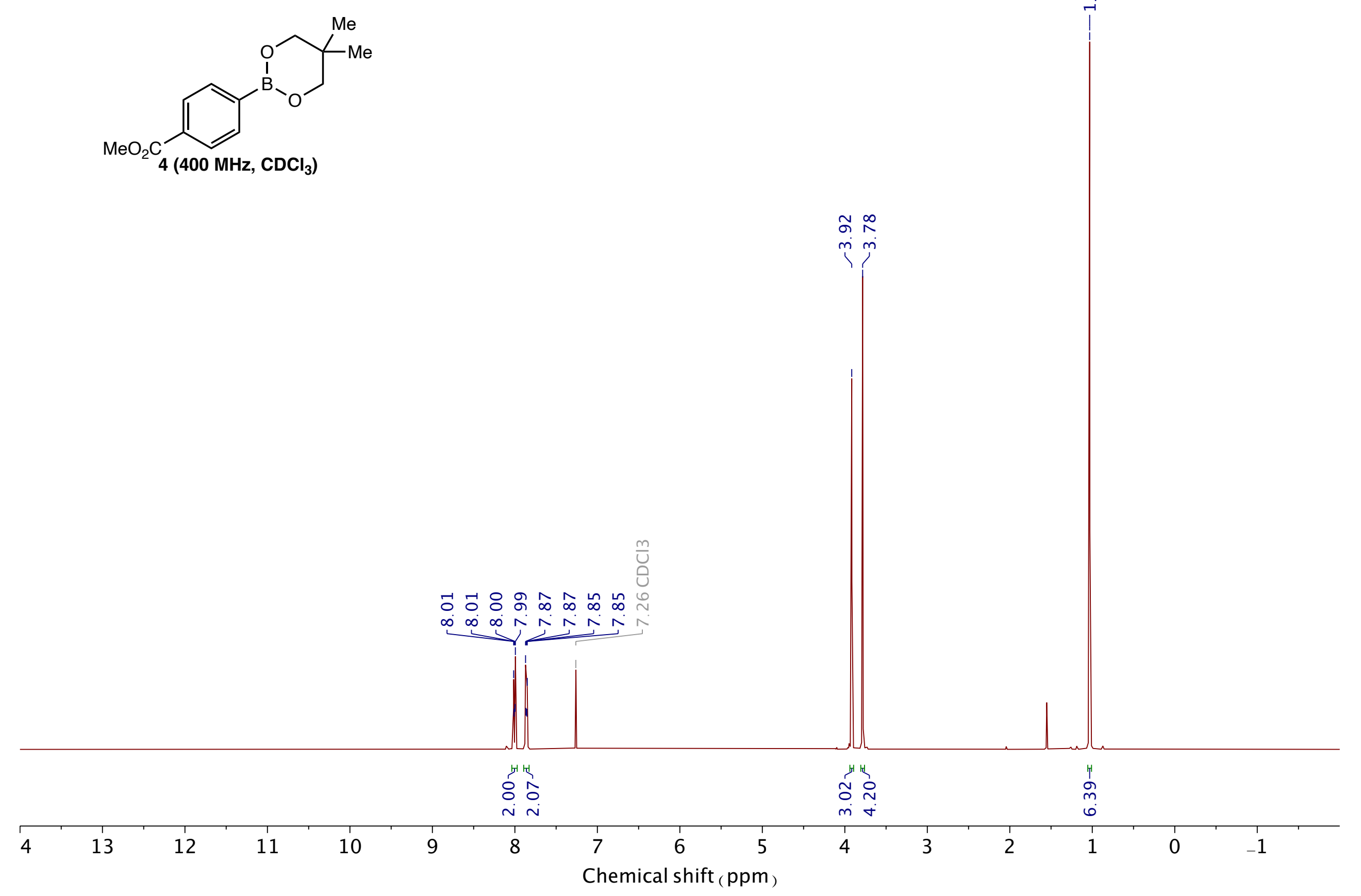


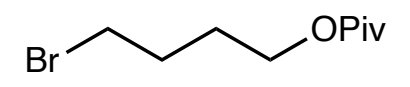

2 (500 MHz, $\left.\mathrm{CDCl}_{3}\right)$

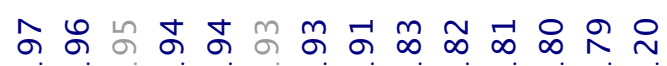

-i $-r i$

암요

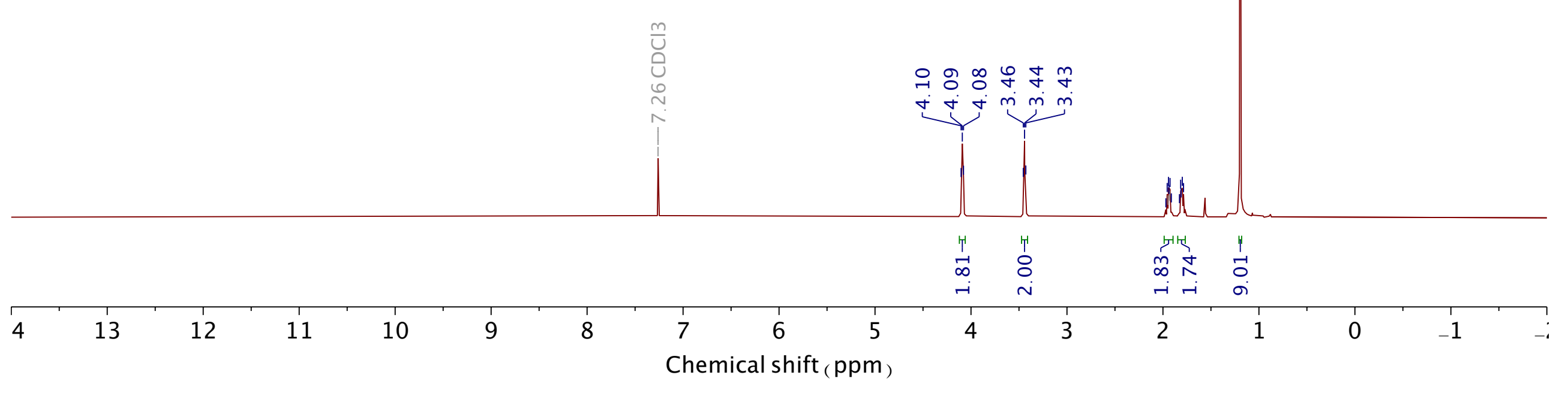




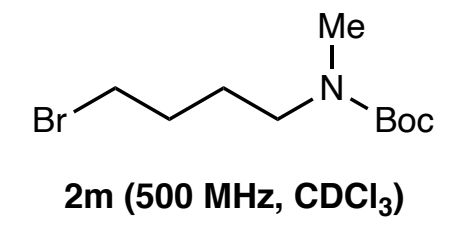

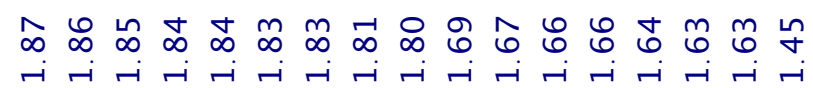

rirr

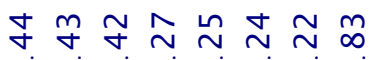

$\dot{m} \dot{m} \dot{m} \dot{m} \sim$

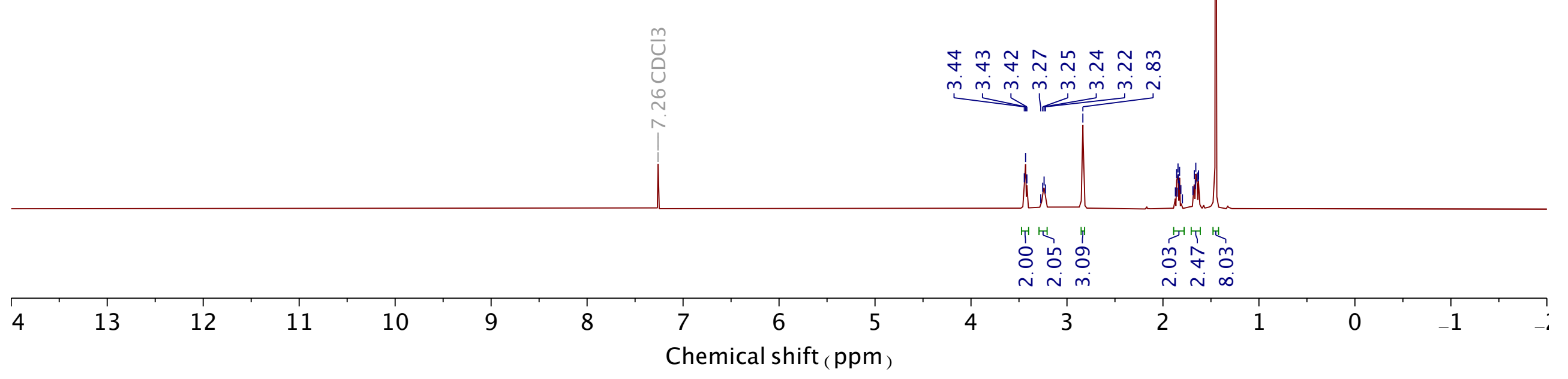




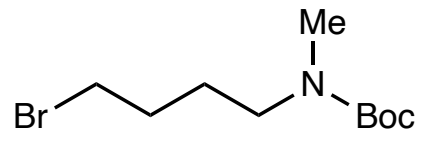

2m (126 MHz, $\left.\mathrm{CDCl}_{3}\right)$

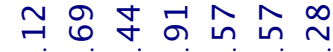

$\underbrace{m} m \dot{m} \sim \underbrace{\infty} \stackrel{i}{\sim}$
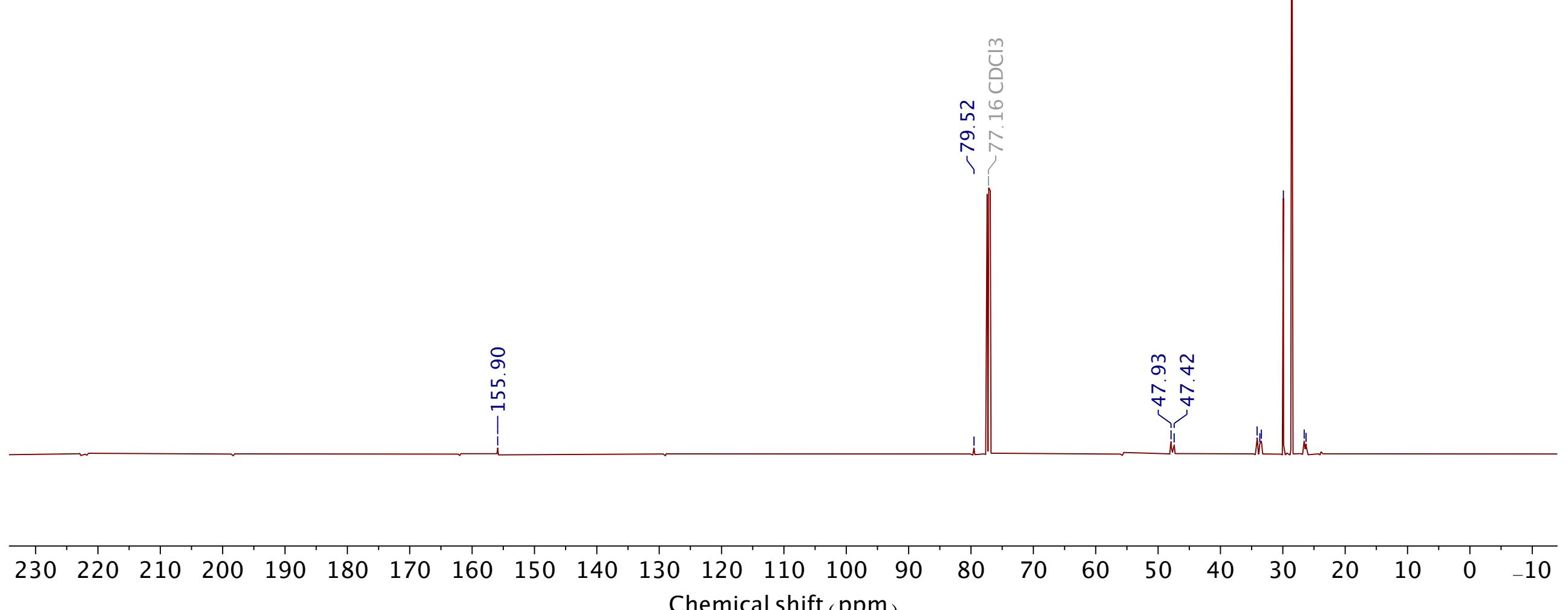

Chemical shift ( ppm) 


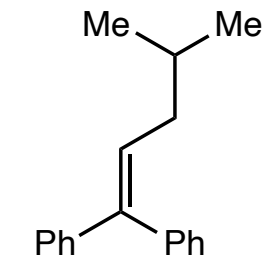

7c $\left(500 \mathrm{MHz}, \mathrm{CDCl}_{3}\right)$
नेळ

이

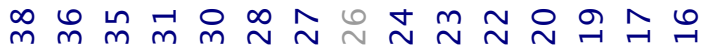

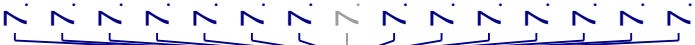

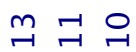

00
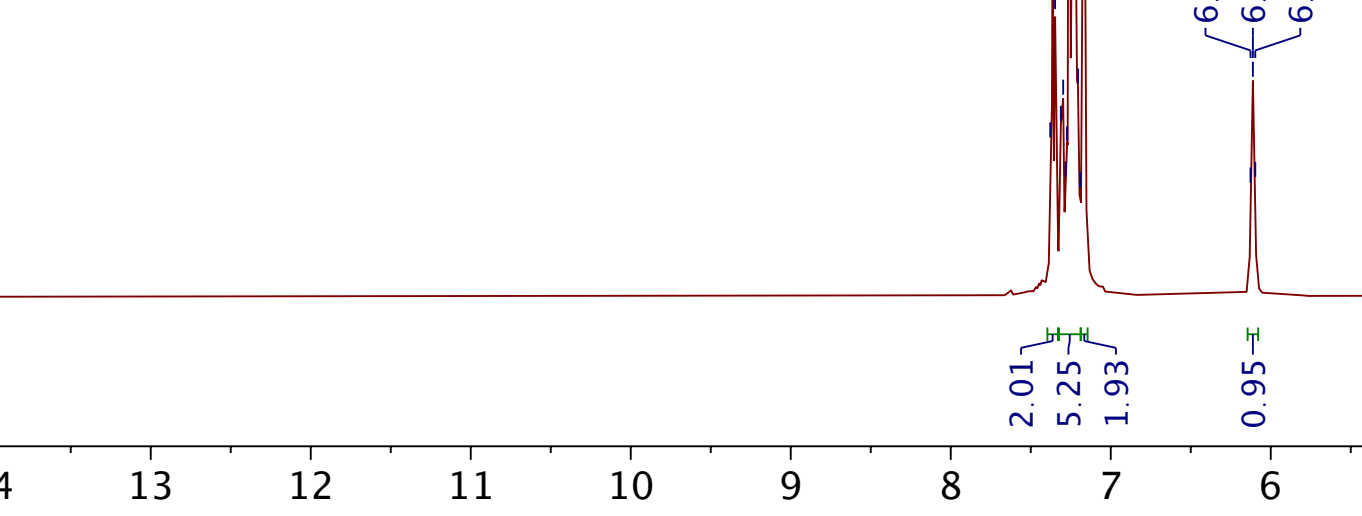

Chemical shift (ppm) 


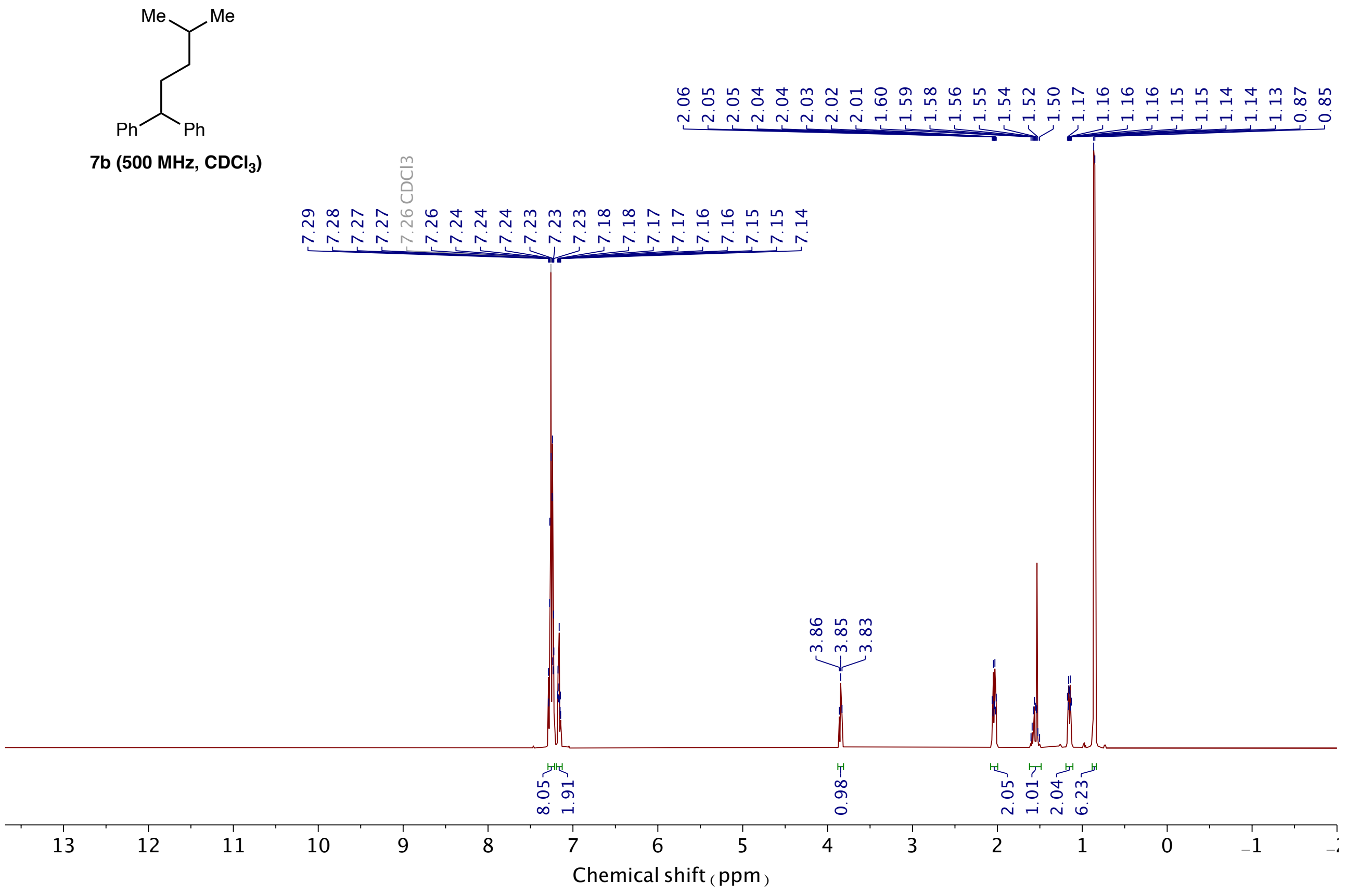




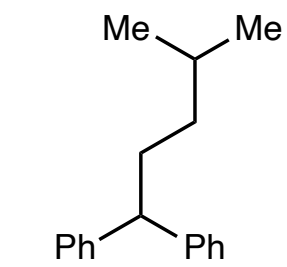

ㄷำ

$\stackrel{\infty}{\sim} \stackrel{0}{\sim}$$$
\text { P }
$$

7b (126 MHz, $\left.\mathrm{CDCl}_{3}\right)$
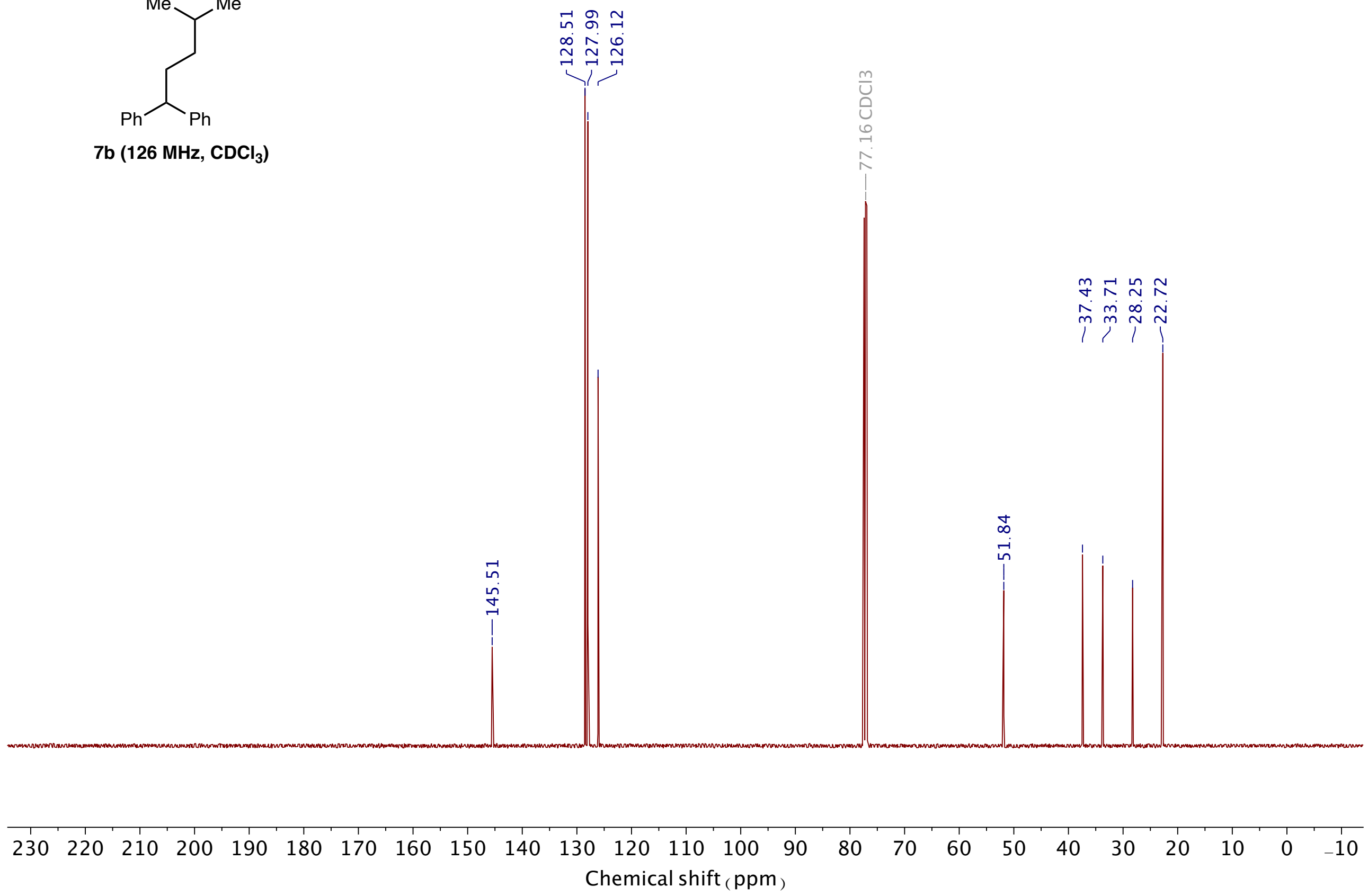


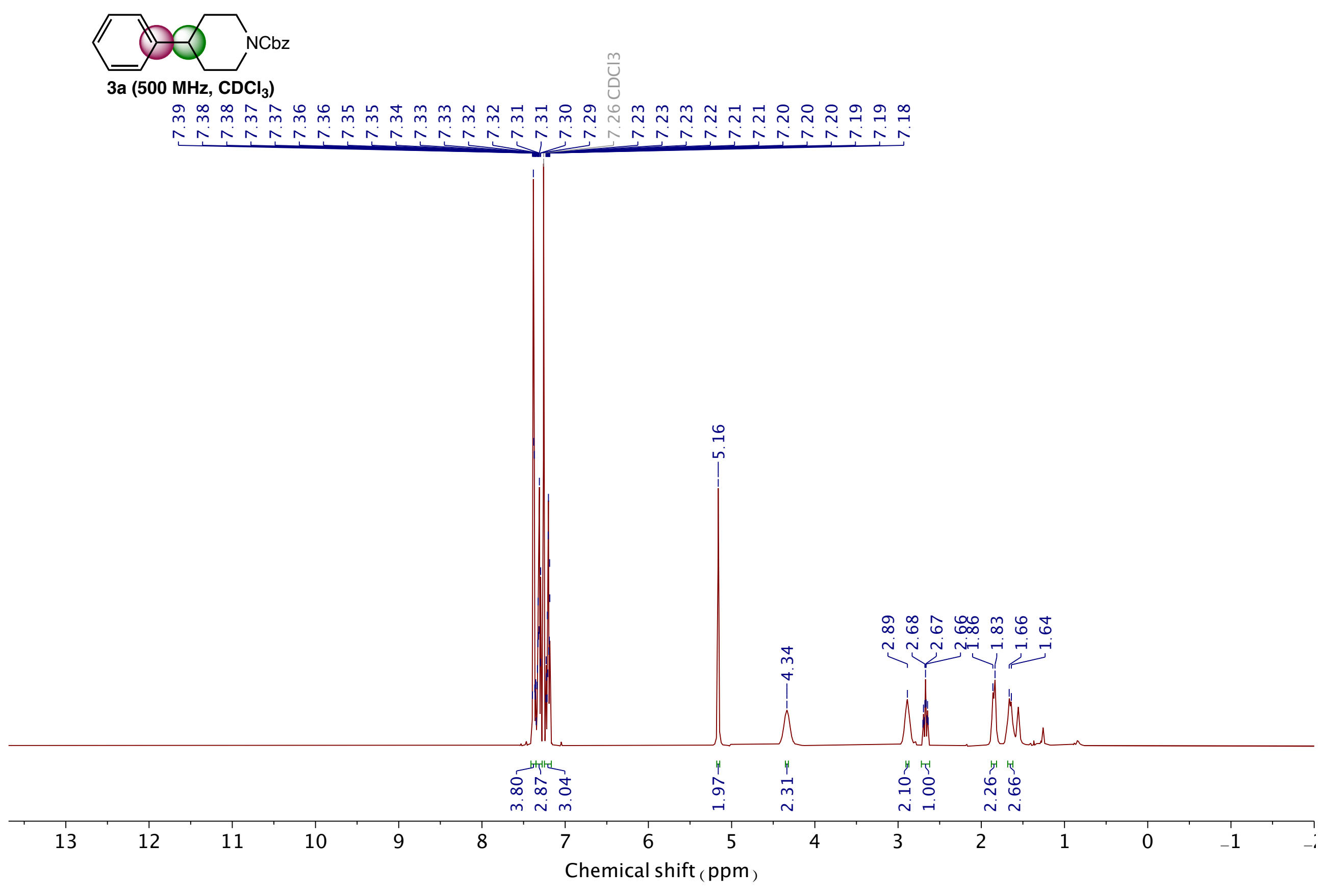




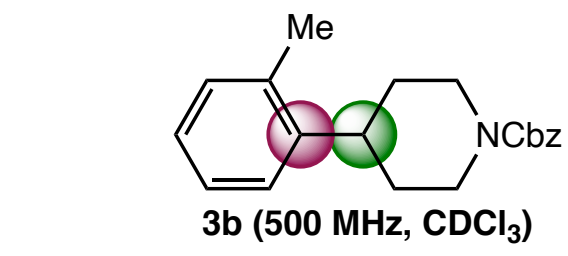

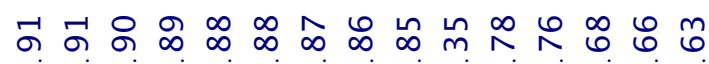

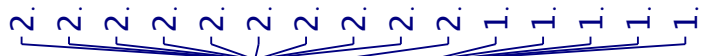

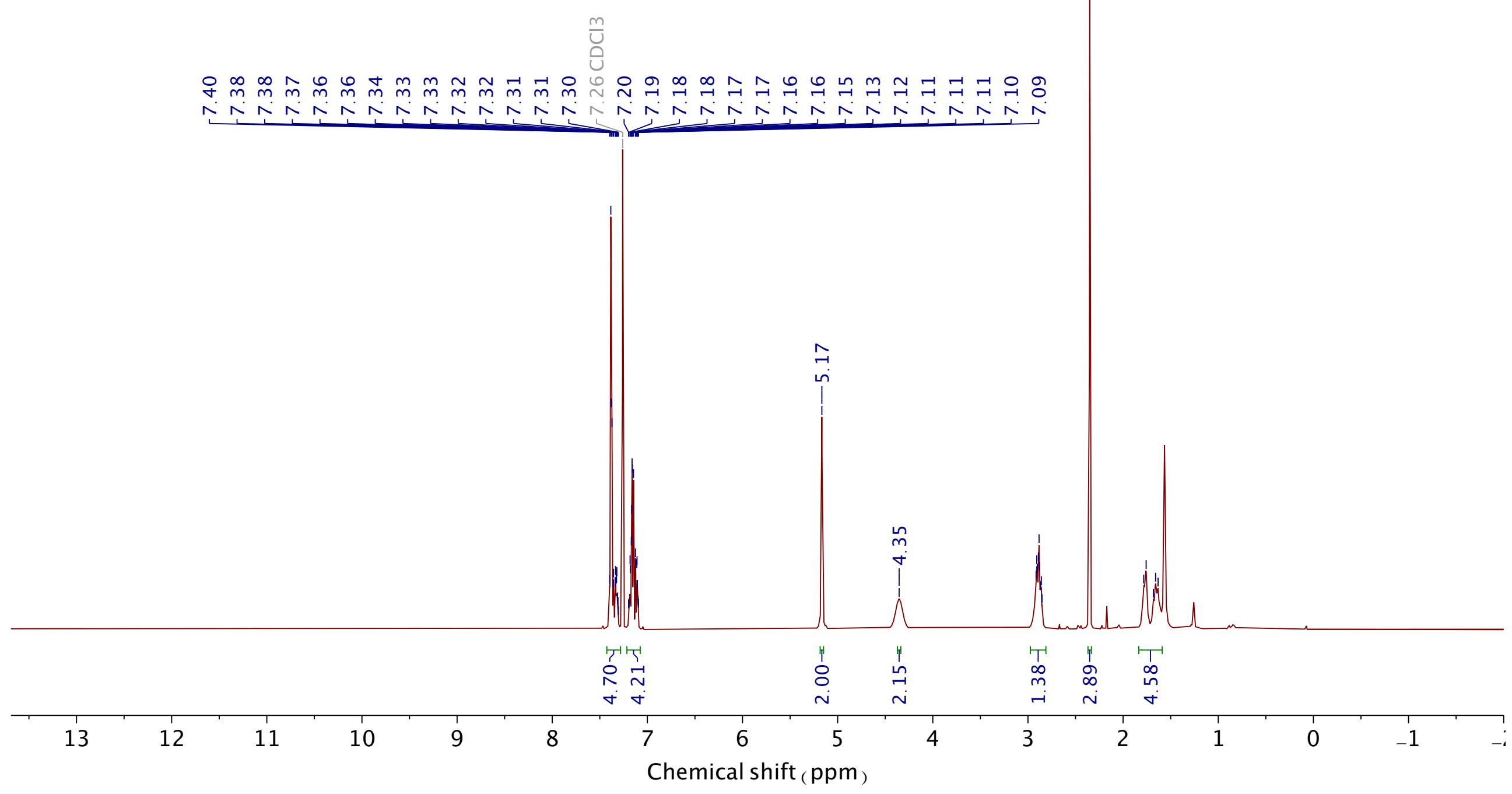




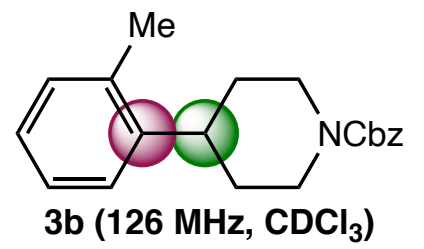

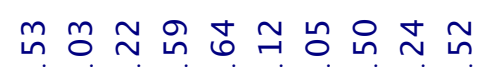

离

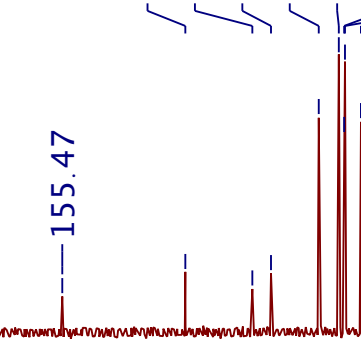

당

หู $\infty \tilde{m}$
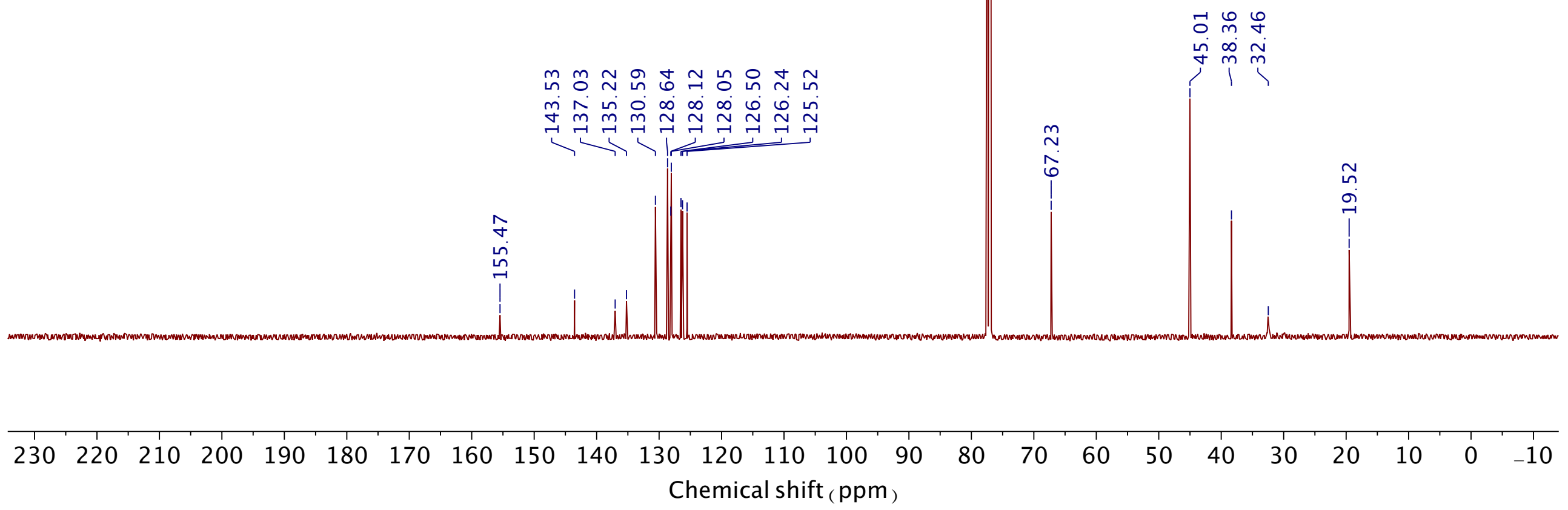


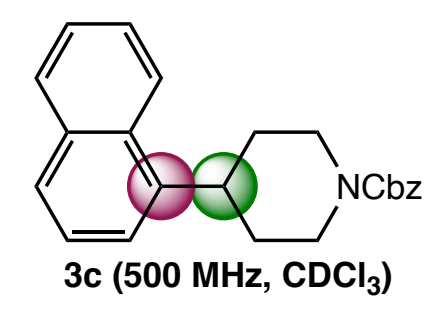

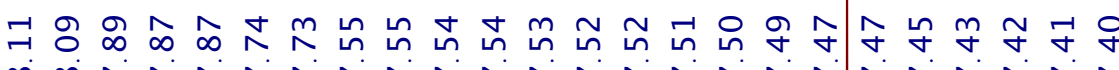

$\stackrel{\infty}{m} \stackrel{\sim}{m} \stackrel{\sim}{m} \stackrel{m}{m} \sim \tilde{m} \tilde{m} \vec{m}$

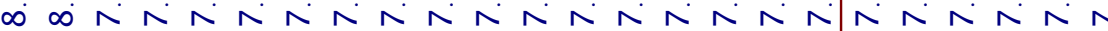

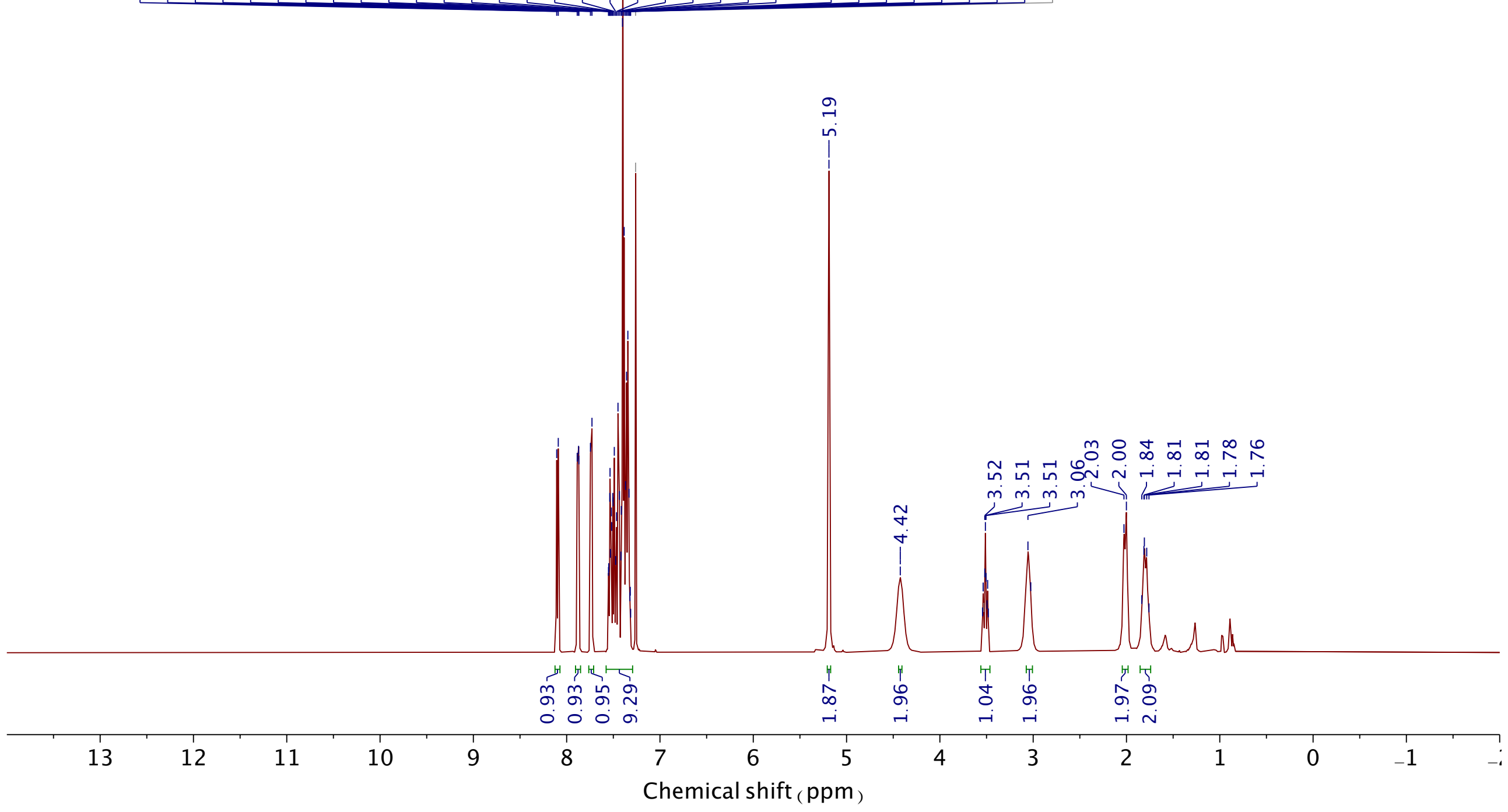




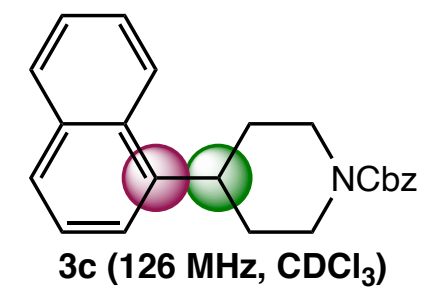

ஸे \&

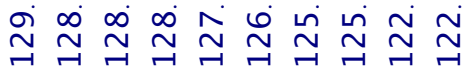

ஃ

म่

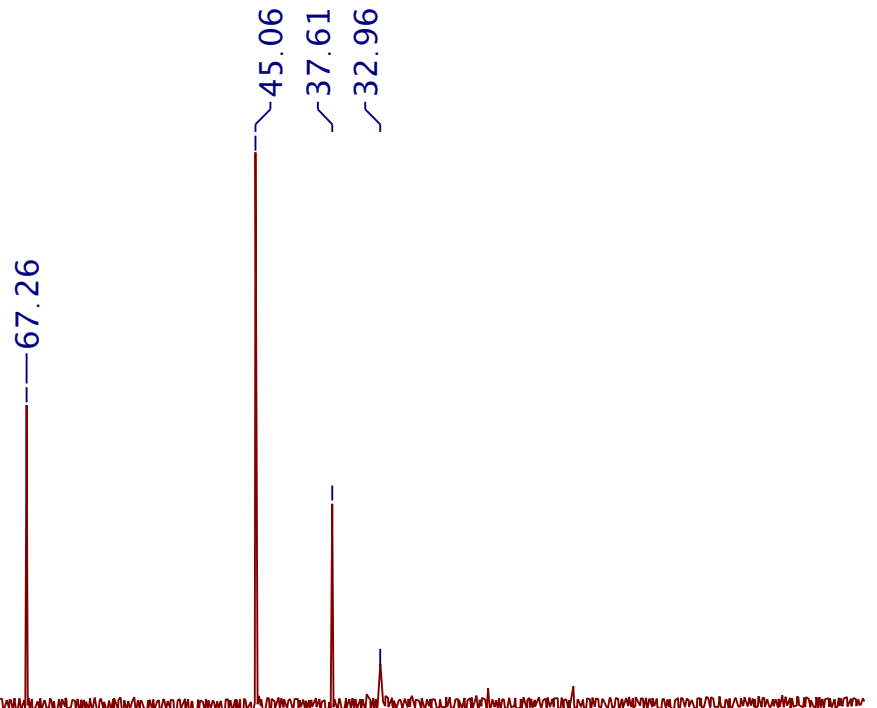

$\begin{array}{rrrrrrrrrrrrrrrrrrrrrrrrrr}230 & 220 & 210 & 200 & 190 & 180 & 170 & 160 & 150 & 140 & 130 & 120 & 110 & 100 & 90 & 80 & 70 & 60 & 50 & 40 & 30 & 20 & 10 & 0 & -10\end{array}$




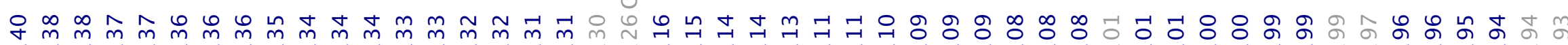

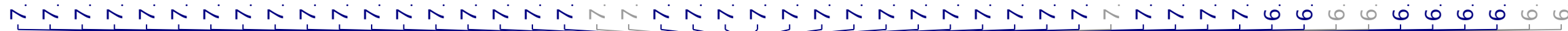
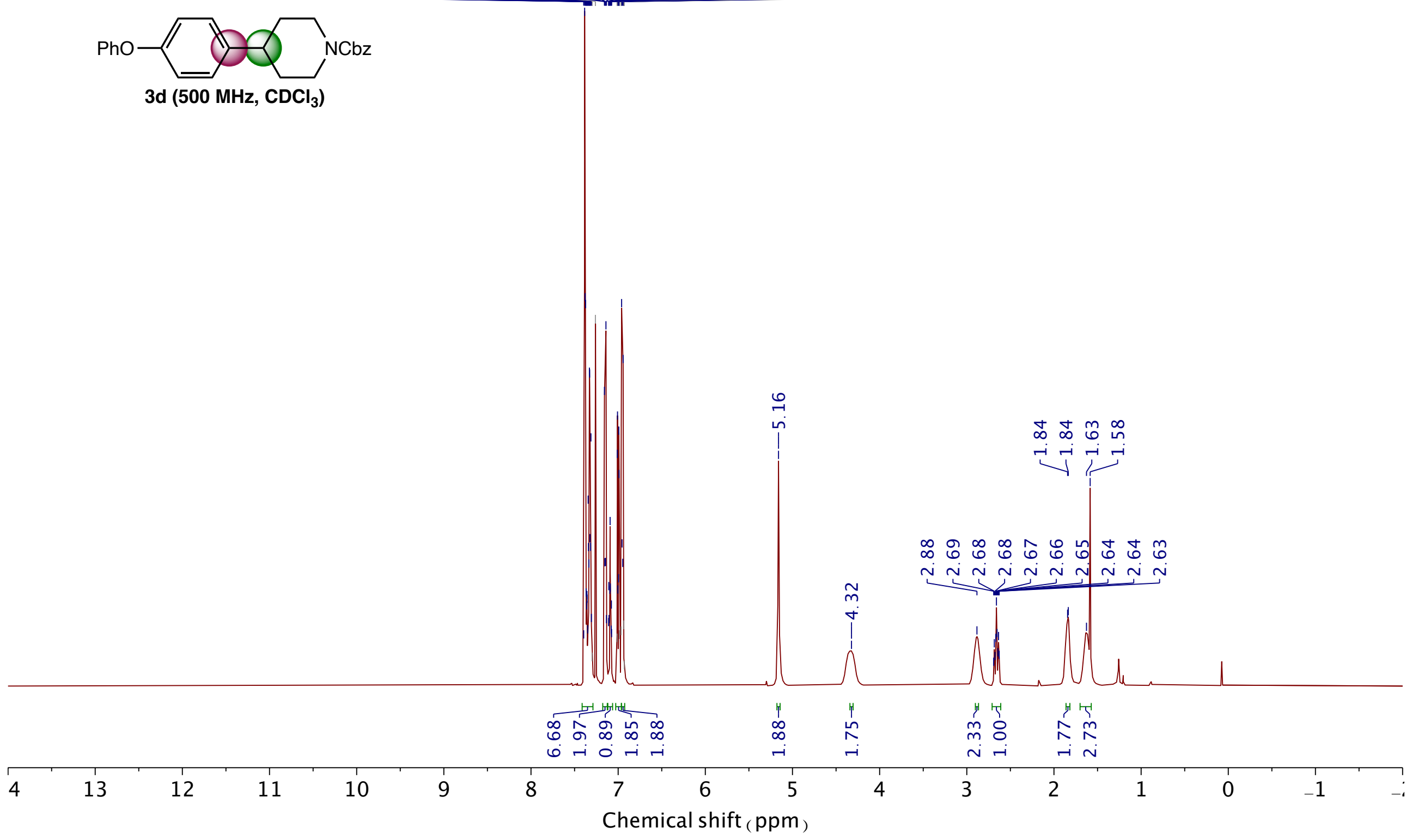


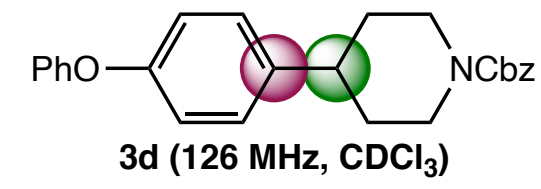

웅요

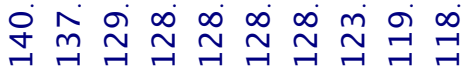

3d (126 MHz, $\left.\mathrm{CDCl}_{3}\right)$

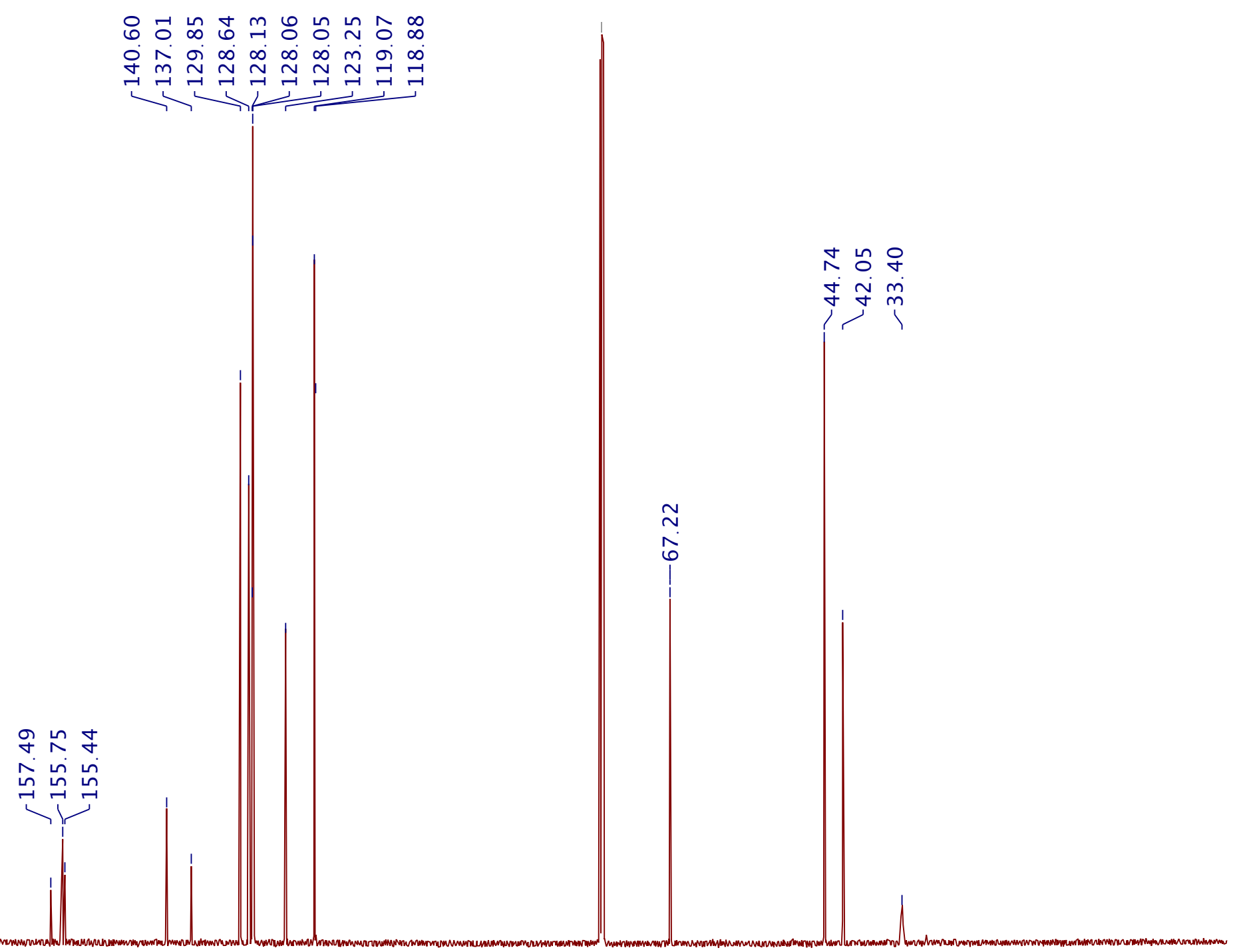

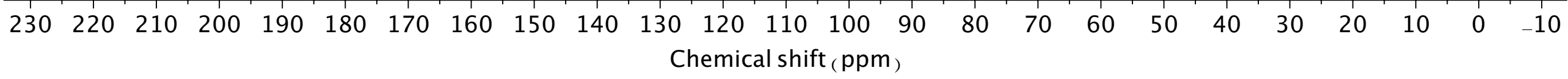




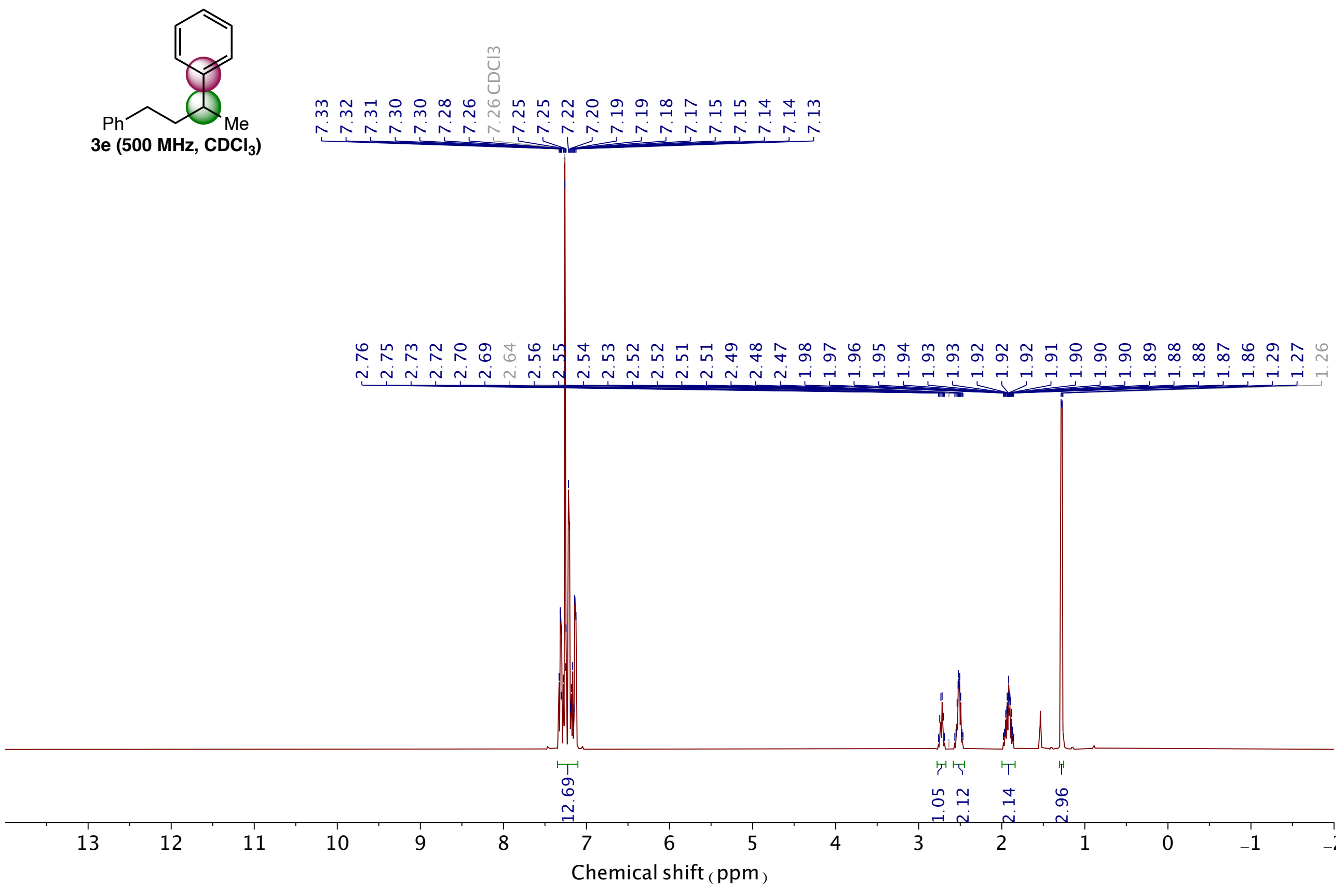




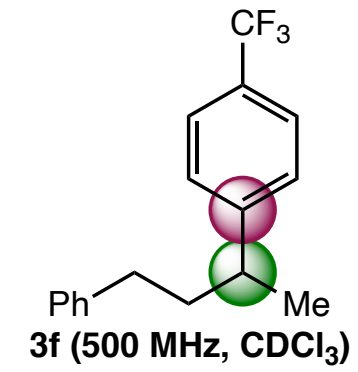

in

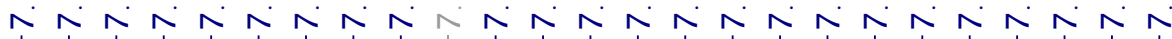

3f $\left(500 \mathrm{MHz}, \mathrm{CDCl}_{3}\right)$

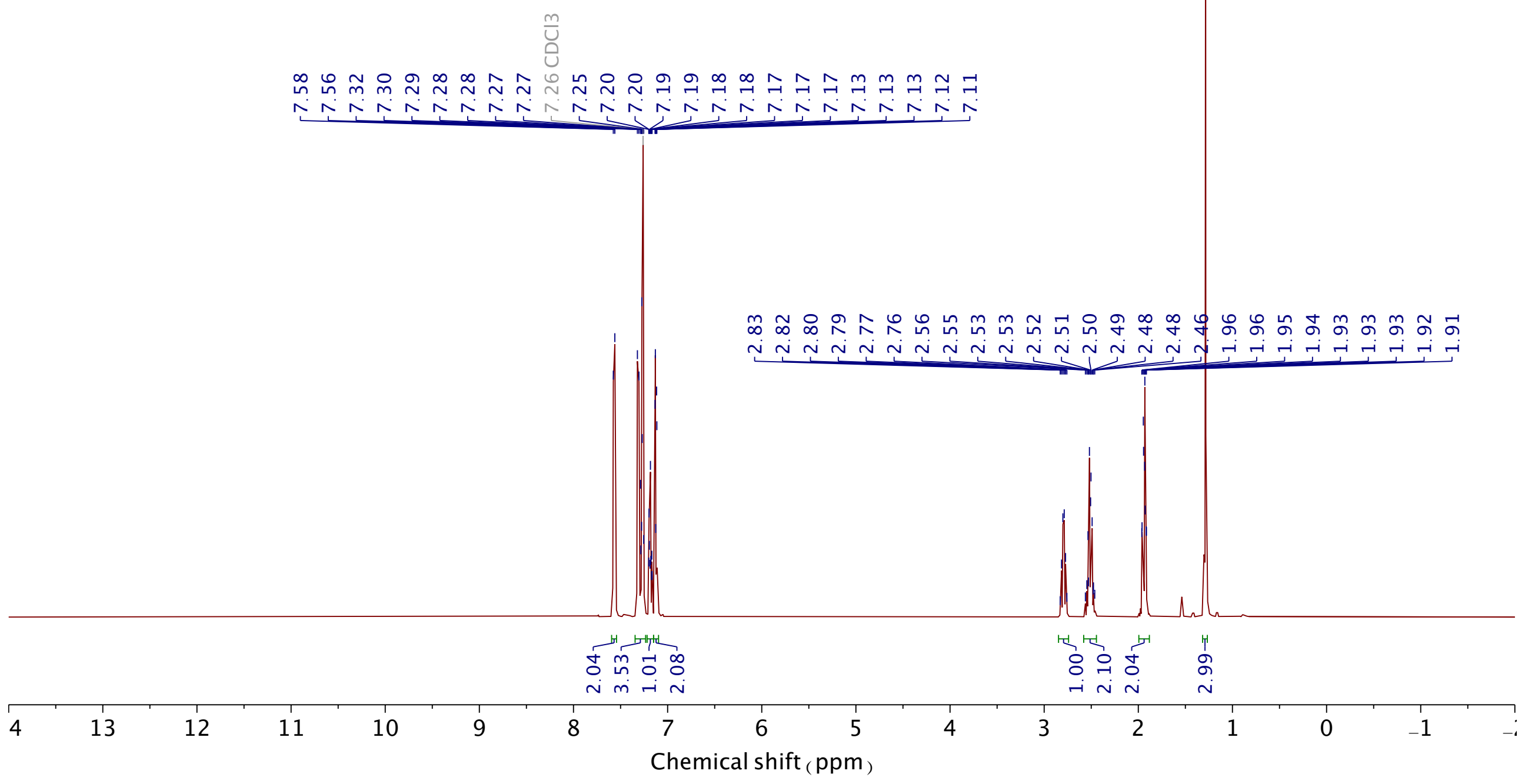




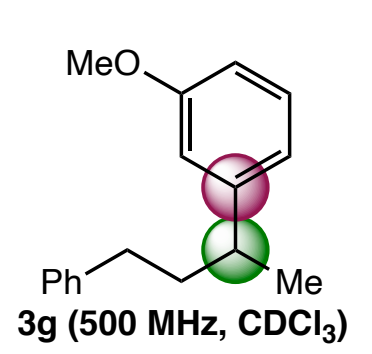

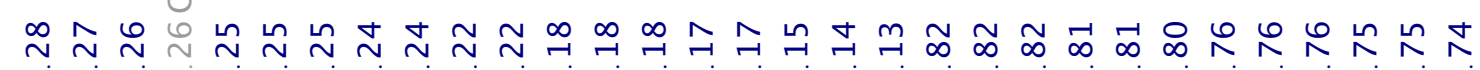
allo

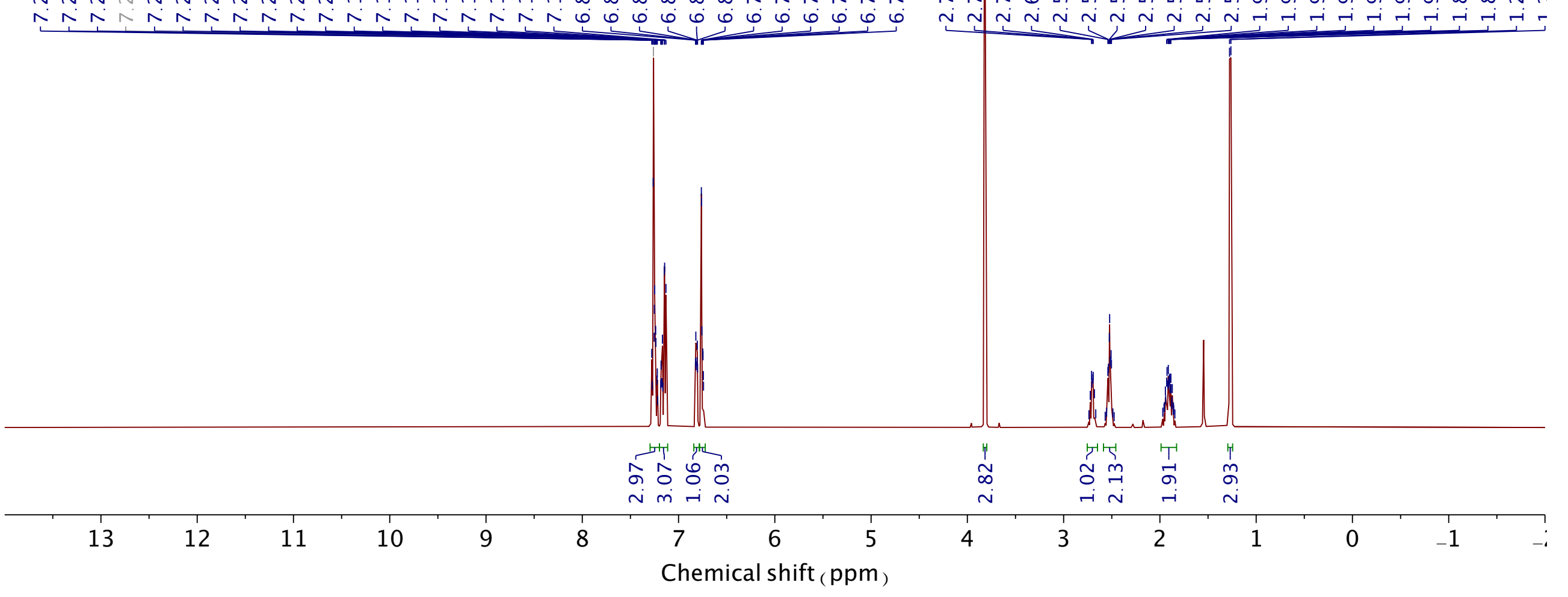



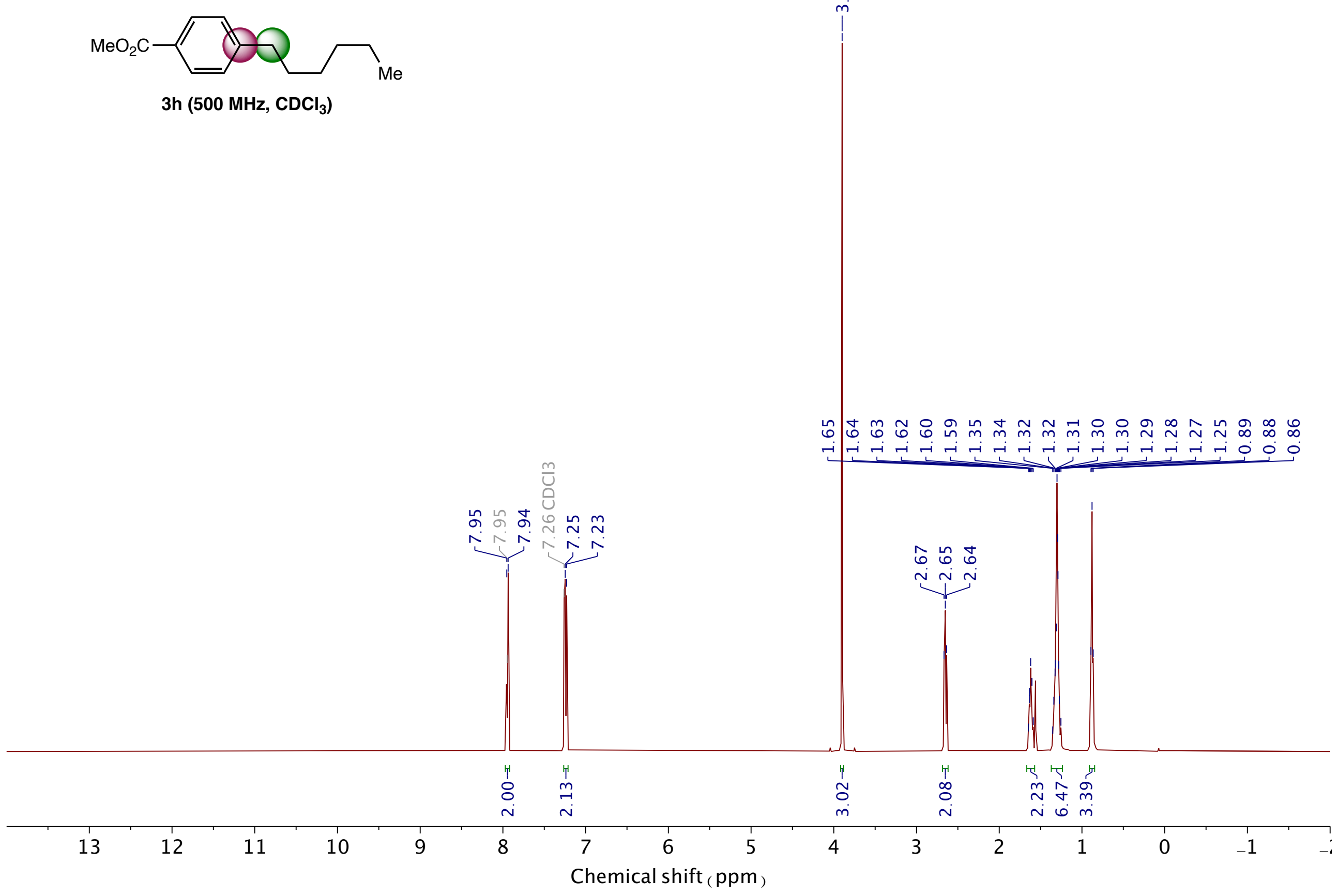

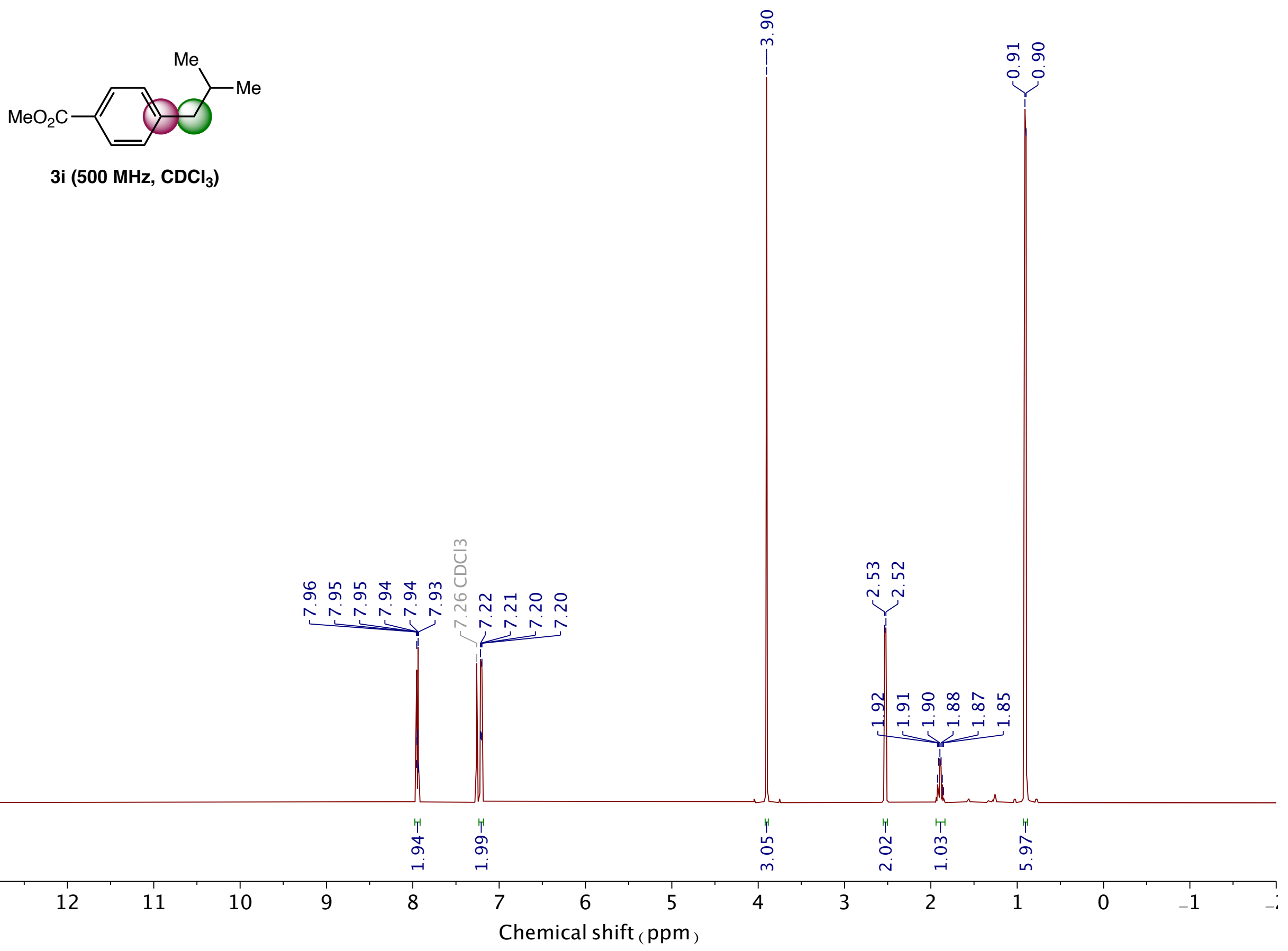

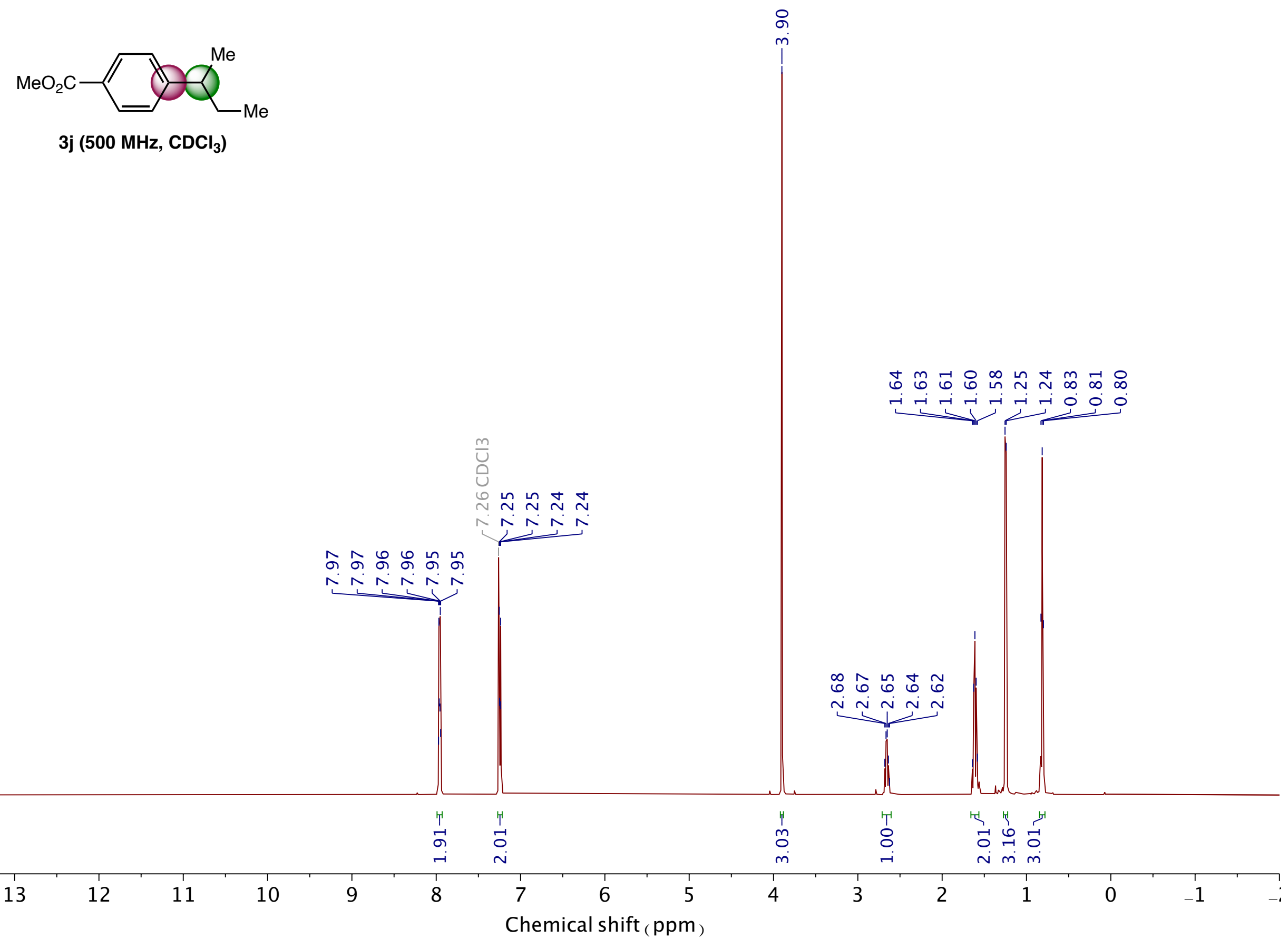


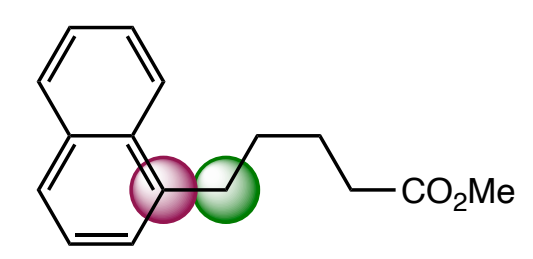

3k (500 $\left.\mathrm{MHz}, \mathrm{CDCl}_{3}\right)$

흑ㅋ우우 웅

$\underbrace{n i m m}$

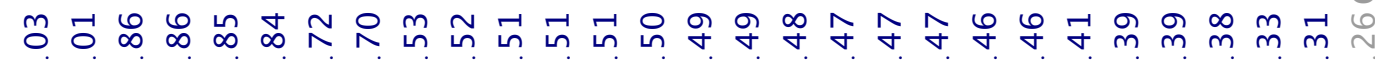

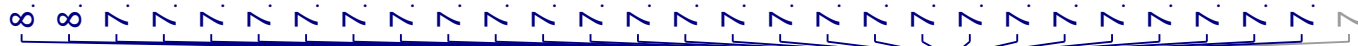

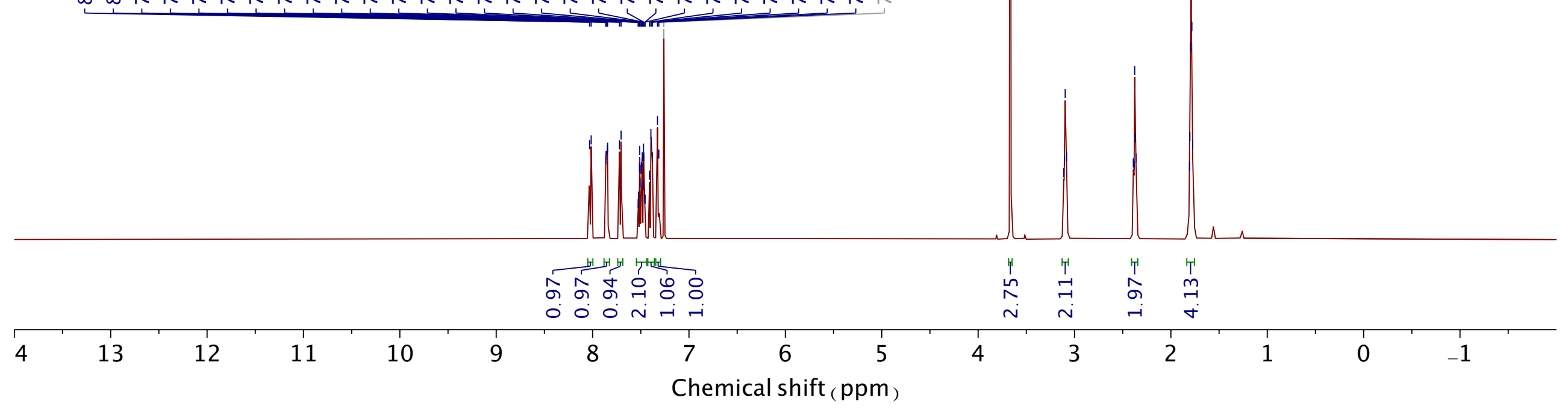




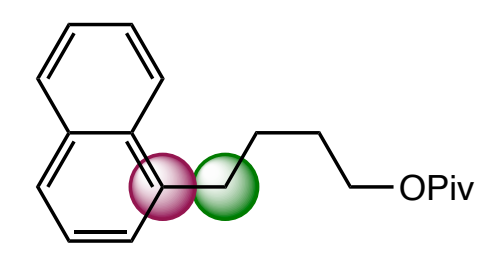

3I $\left(500 \mathrm{MHz}, \mathrm{CDCl}_{3}\right)$

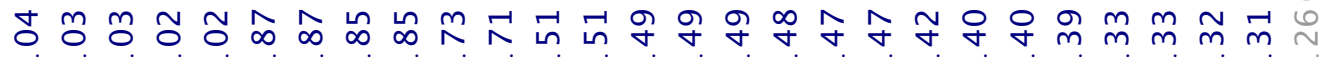

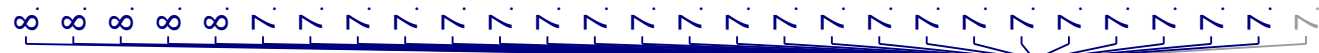

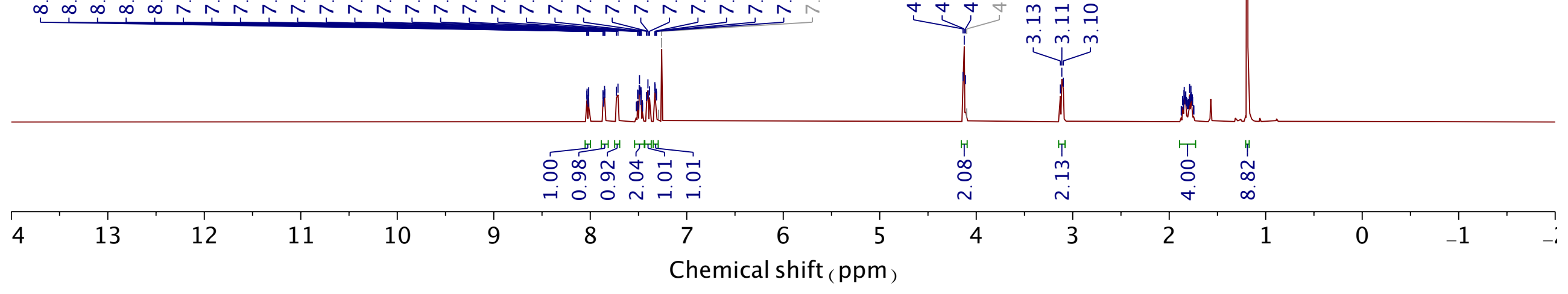




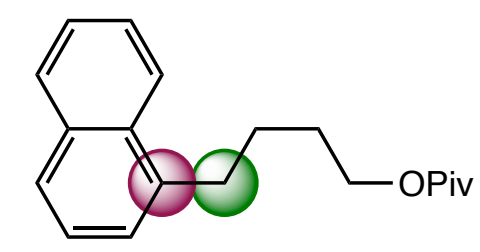

3I (126 MHz, $\left.\mathrm{CDCl}_{3}\right)$

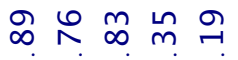

$\infty \sim \infty \sim \infty \sim$

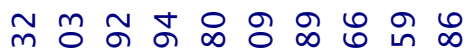

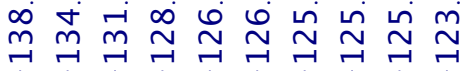

$\infty$

$\stackrel{\infty}{\rightarrow}$

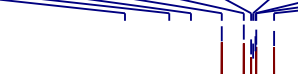

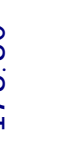

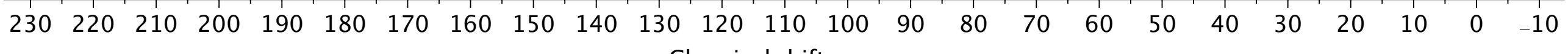

Chemical shift (ppm) 


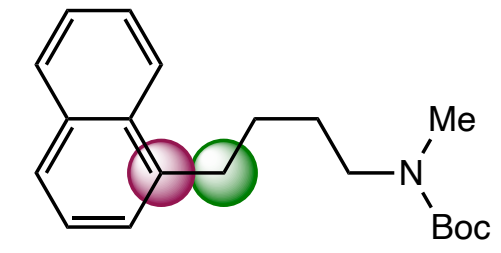

$3 \mathrm{~m}\left(500 \mathrm{MHz}, \mathrm{CDCl}_{3}\right)$

ఫ 0 ○

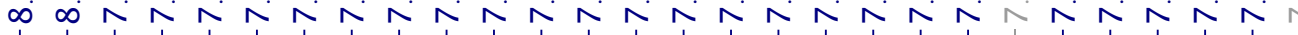

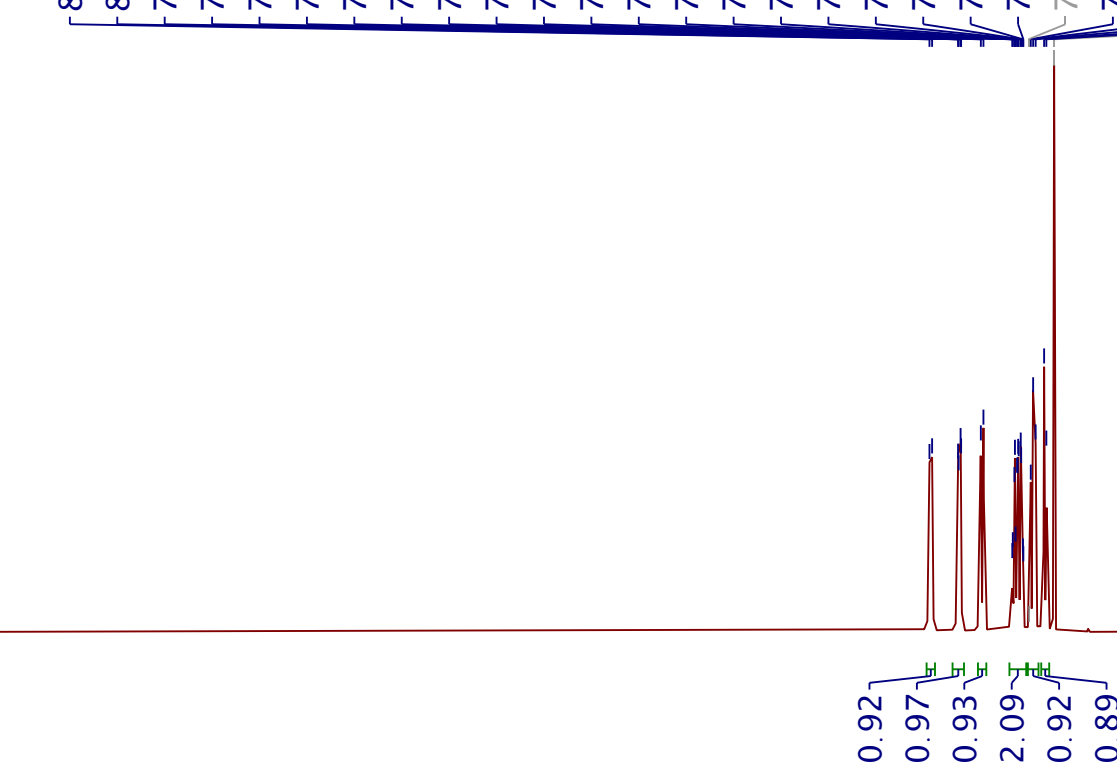

13

(1)

$8+7$

$12 \quad 11$

10

9

Chemical shift (ppm)

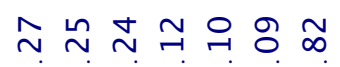

$\underbrace{n \dot{n} m i n}$

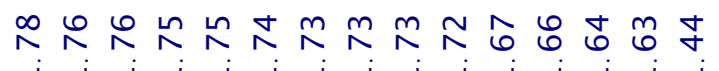

-i -i ri ri 


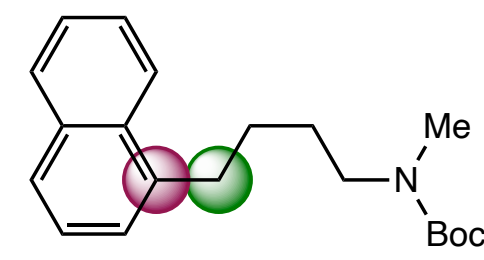

3m (126 MHz, $\mathrm{CDCl}_{3}$ )

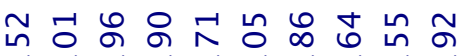

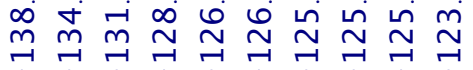

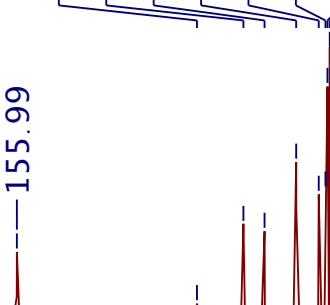

효 8 \&

+ $\sim$

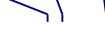

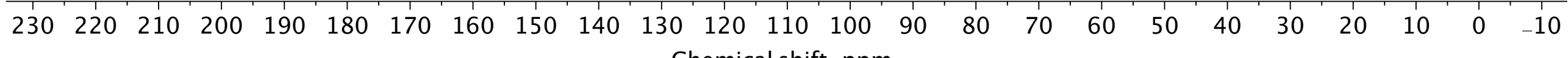




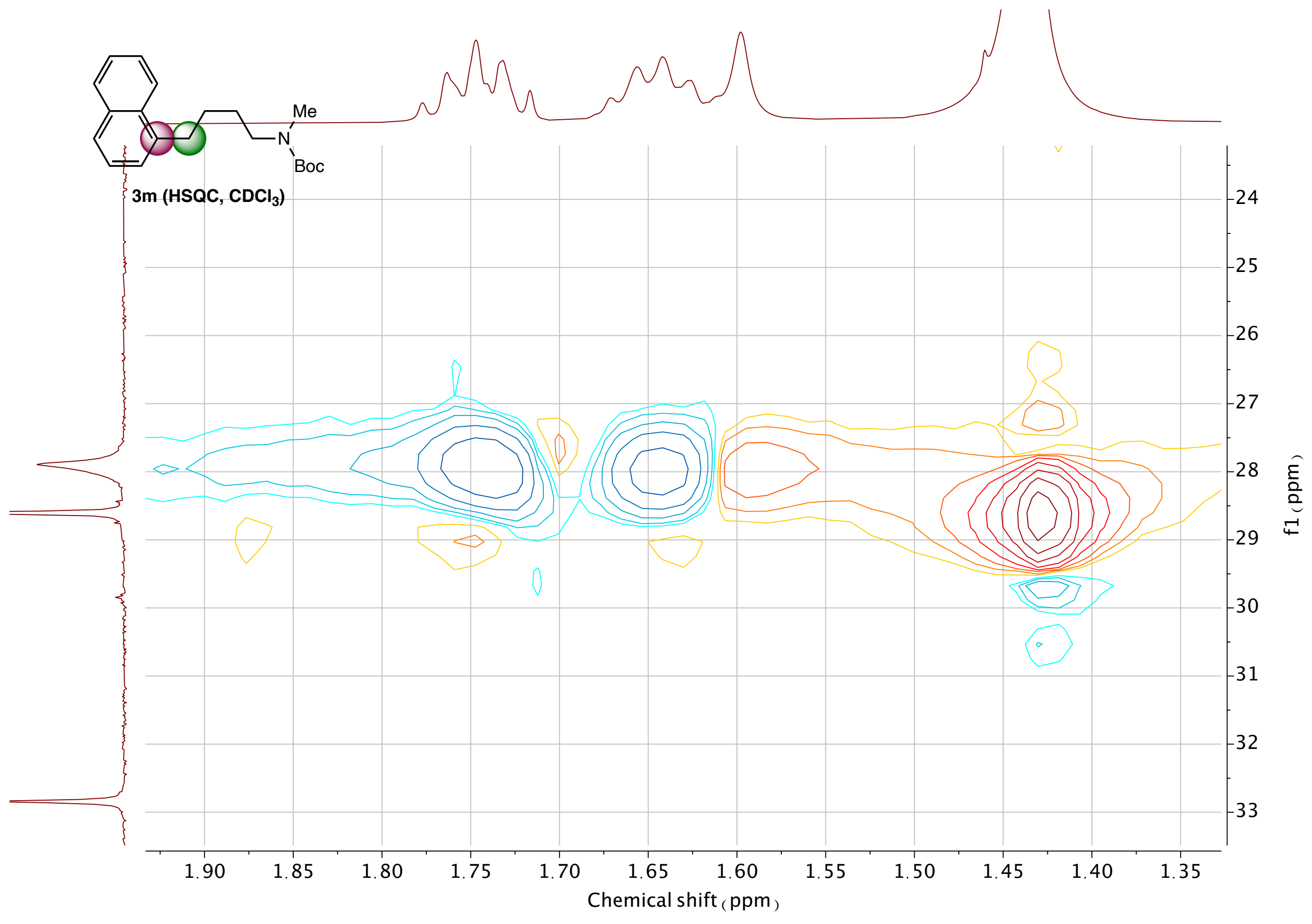




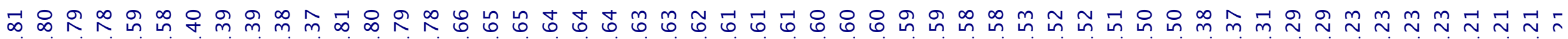

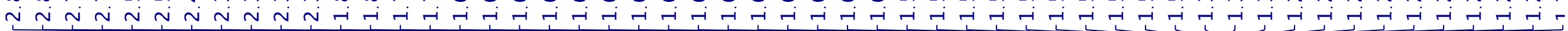

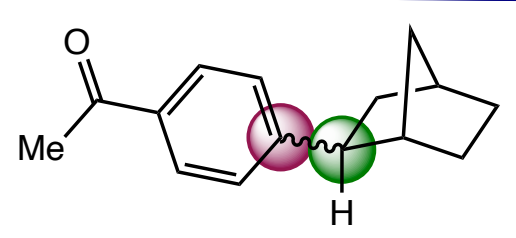

3n $\left(500 \mathrm{MHz}, \mathrm{CDCl}_{3}\right)$

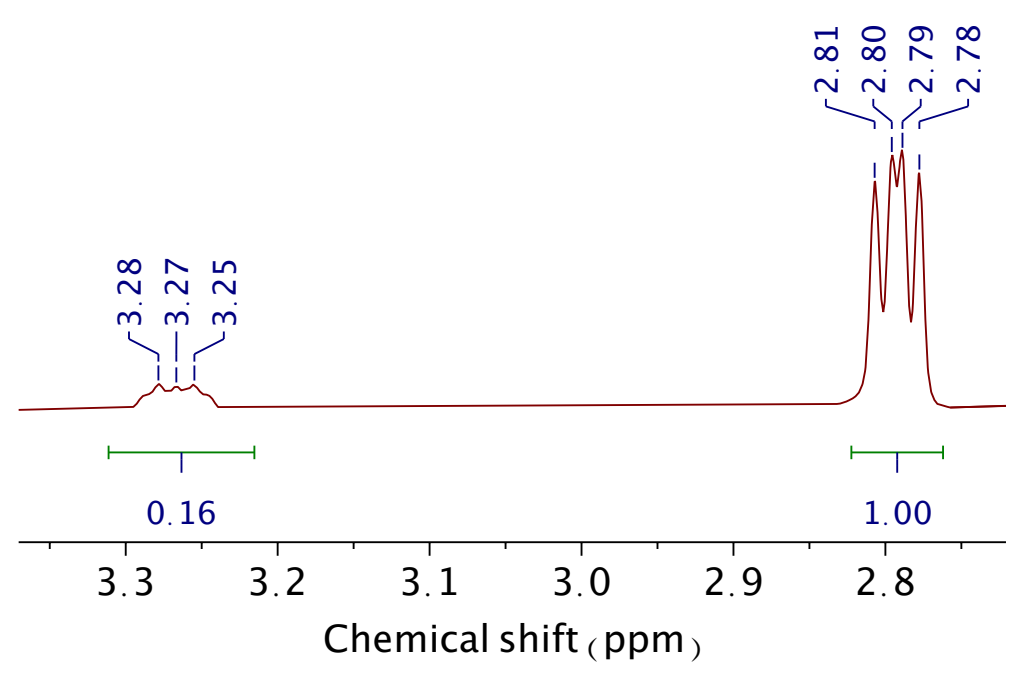

नु

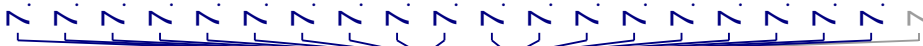

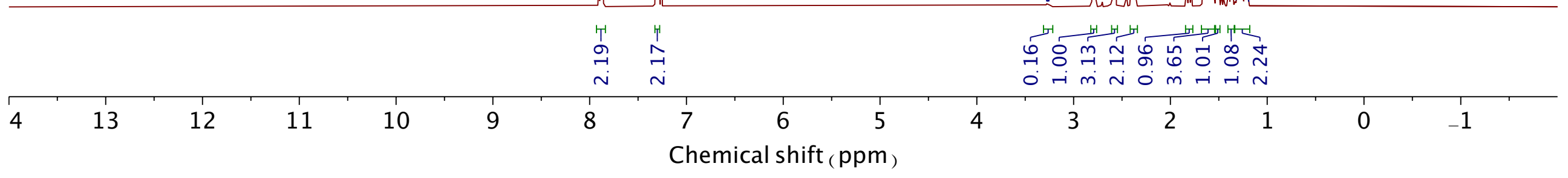




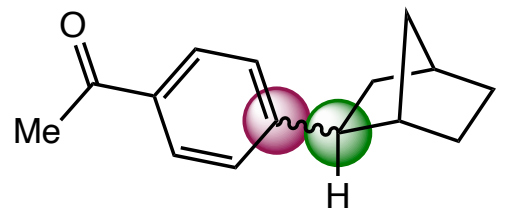

3n (126 $\left.\mathrm{MHz}, \mathrm{CDCl}_{3}\right)$

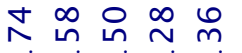

$\stackrel{+}{\rightarrow} \stackrel{\infty}{\sim} \stackrel{\infty}{\sim} \underset{\sim}{\stackrel{\infty}{\sim}} \stackrel{\sim}{\sim}$

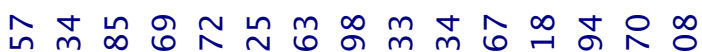

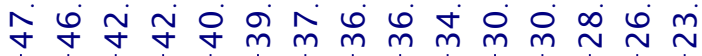

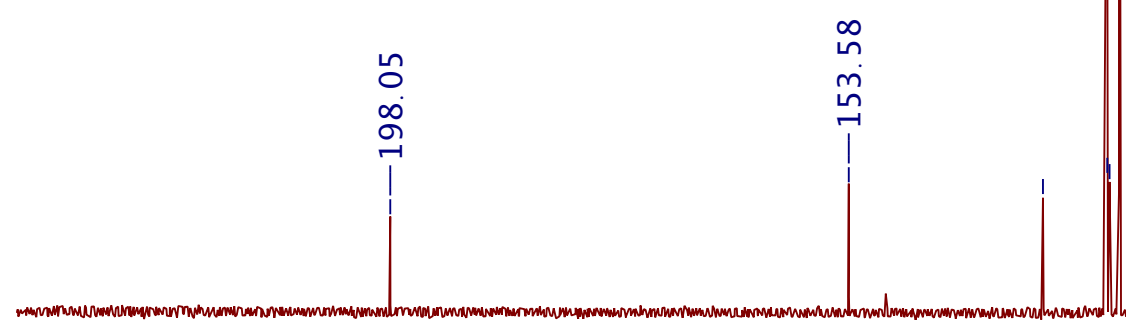

$\begin{array}{rrrrrrrrrrrrrrrrrrrrrrrrrr}230 & 220 & 210 & 200 & 190 & 180 & 170 & 160 & 150 & 140 & 130 & 120 & 110 & 100 & 90 & 80 & 70 & 60 & 50 & 40 & 30 & 20 & 10 & 0 & -10\end{array}$




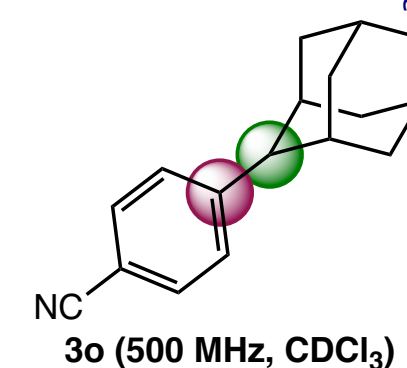

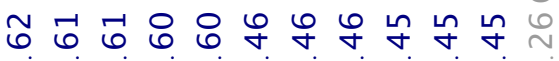

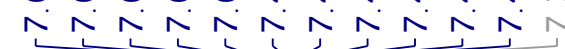
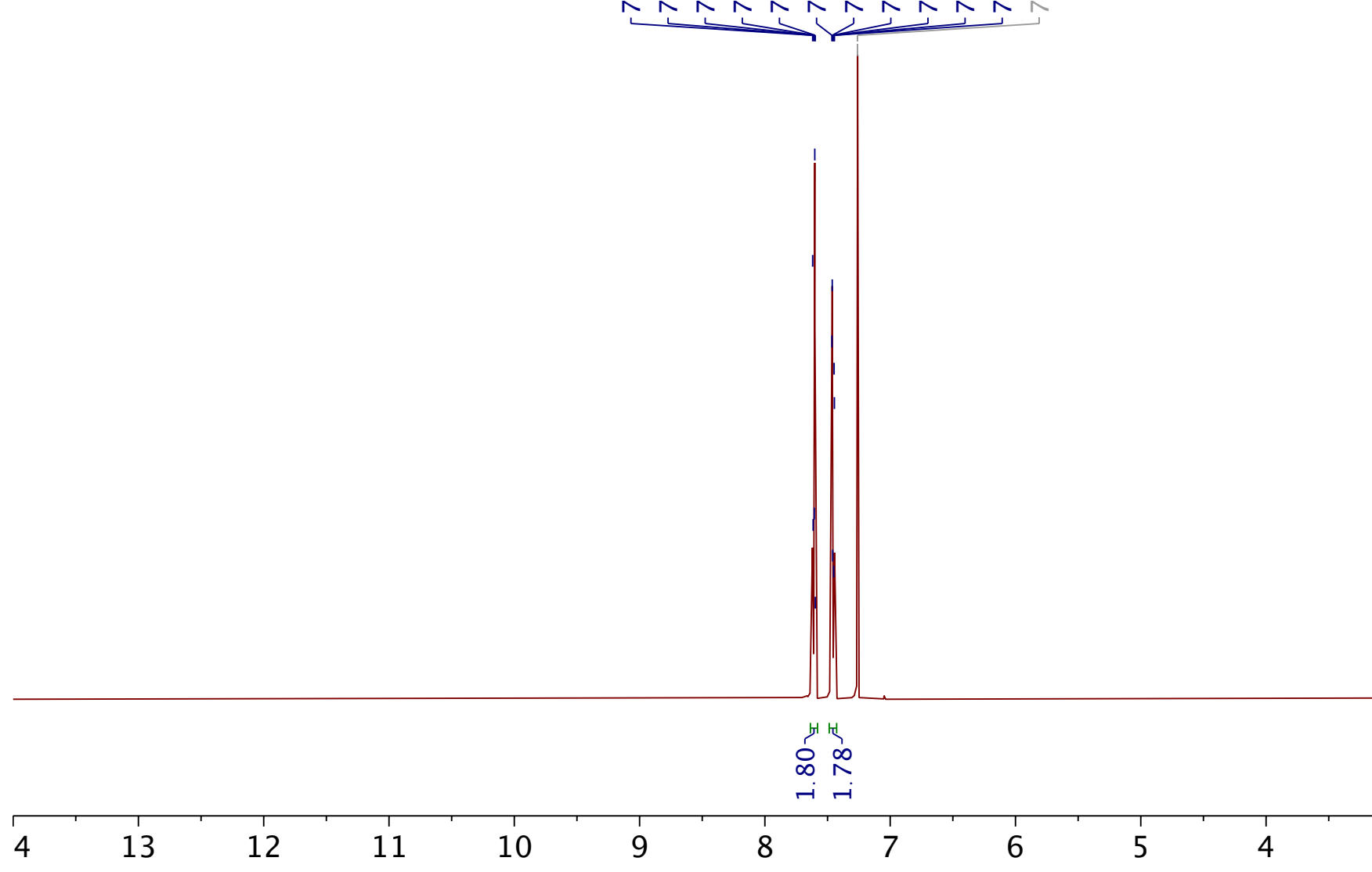

$\int^{1} \infty$

4 H

の

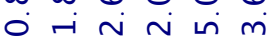

12

11

Chemical shift $(\mathrm{ppm})$ 


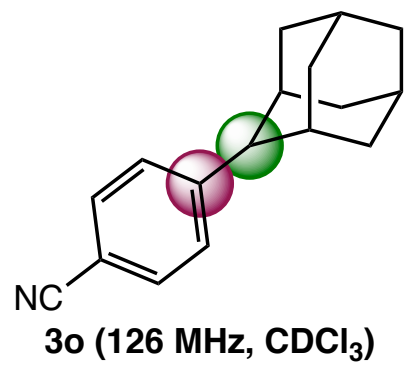

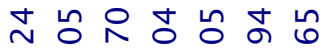

fं

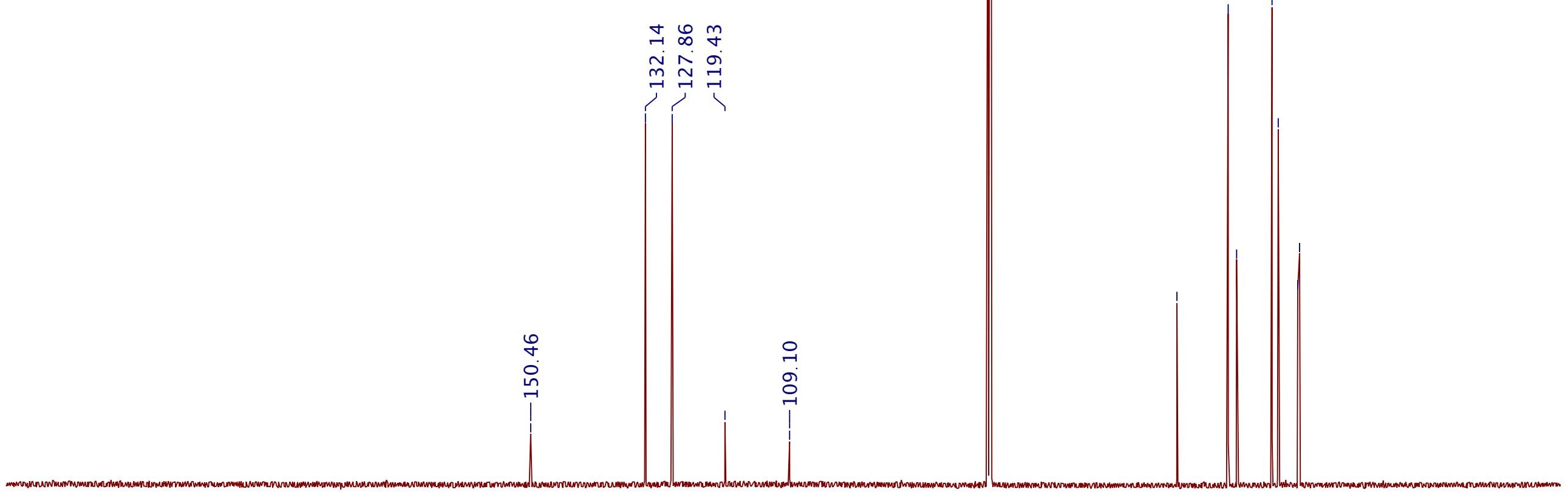

$\begin{array}{rrrrrrrrrrrrrrrrrrrrrrrrrr}230 & 220 & 210 & 200 & 190 & 180 & 170 & 160 & 150 & 140 & 130 & 120 & 110 & 100 & 90 & 80 & 70 & 60 & 50 & 40 & 30 & 20 & 10 & 0 & -10\end{array}$




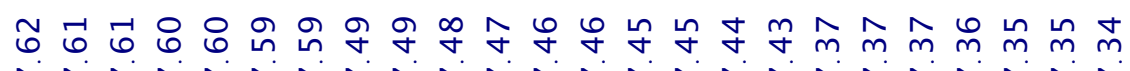

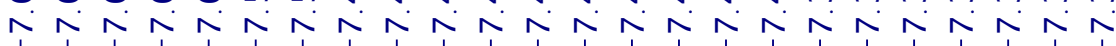

$\mathrm{Ph}$

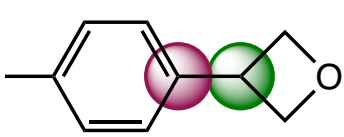

$3 p\left(500 \mathrm{MHz}, \mathrm{CDCl}_{3}\right)$

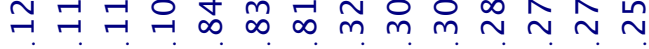

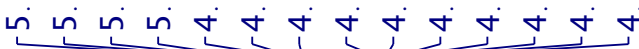

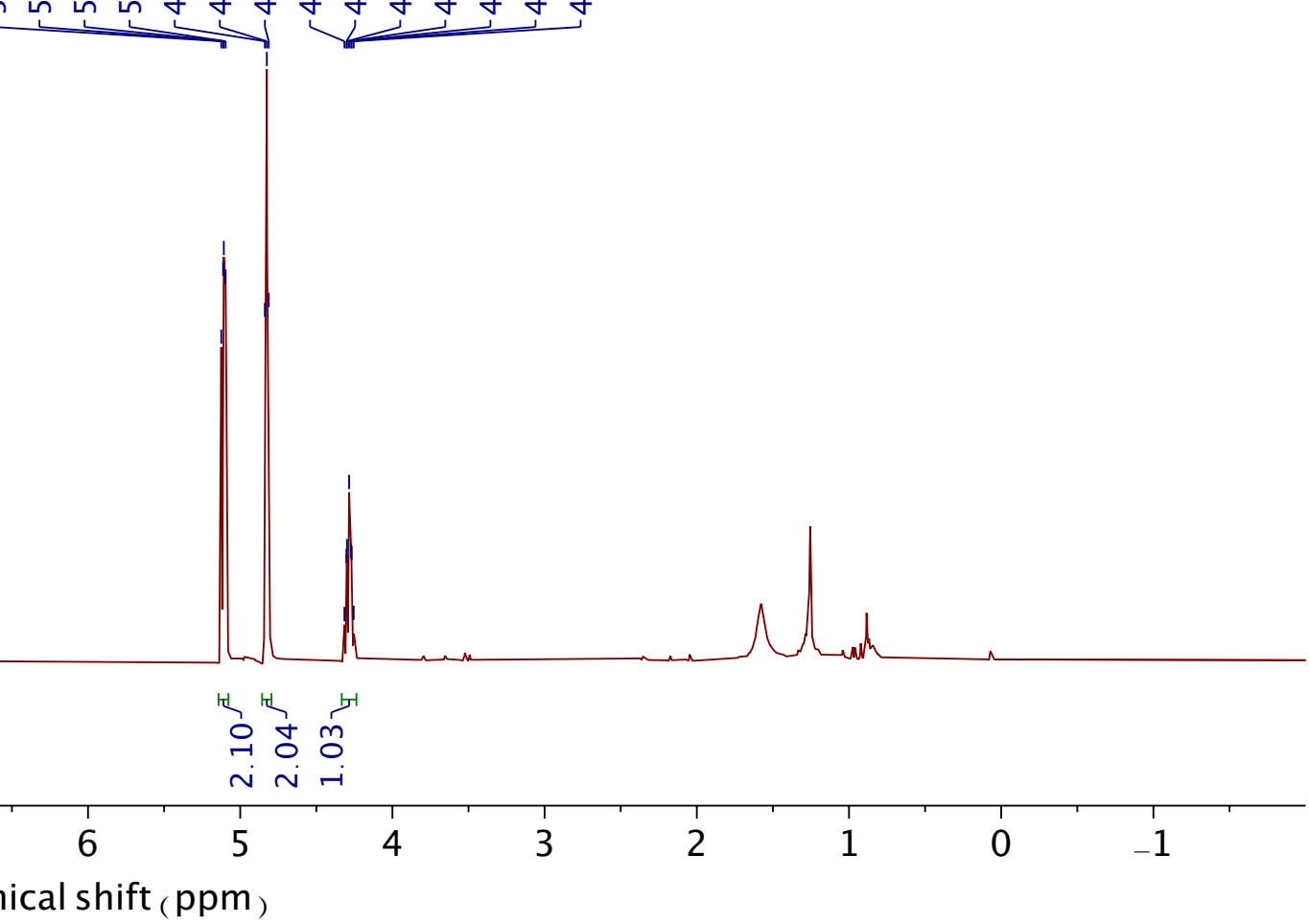




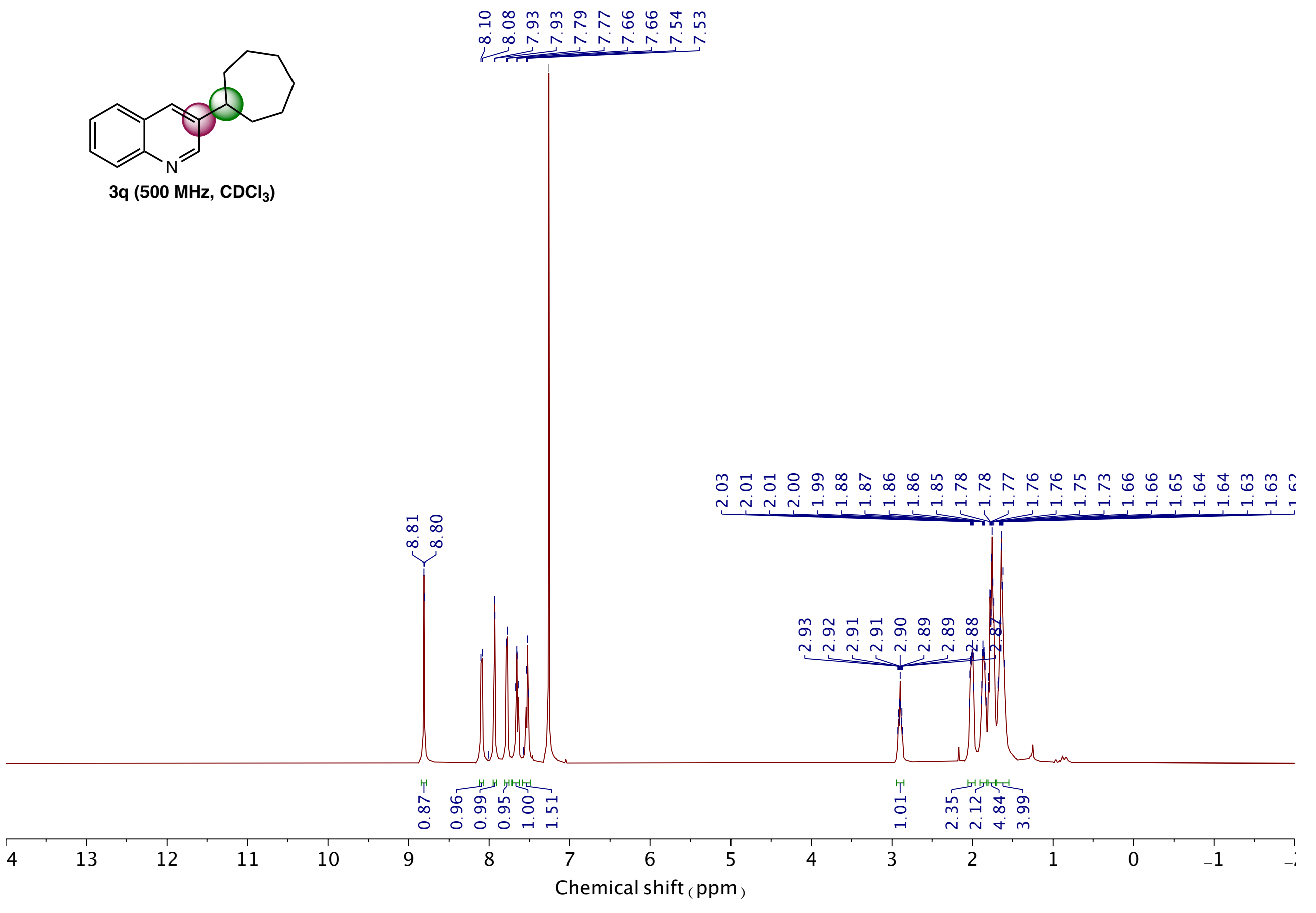




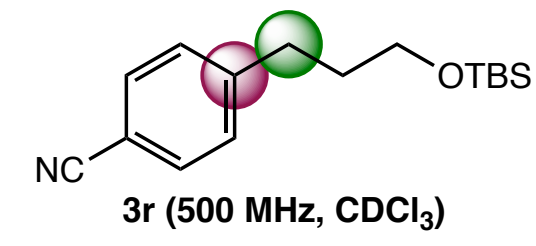

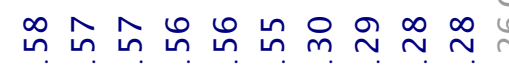

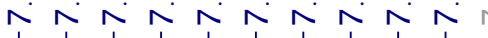

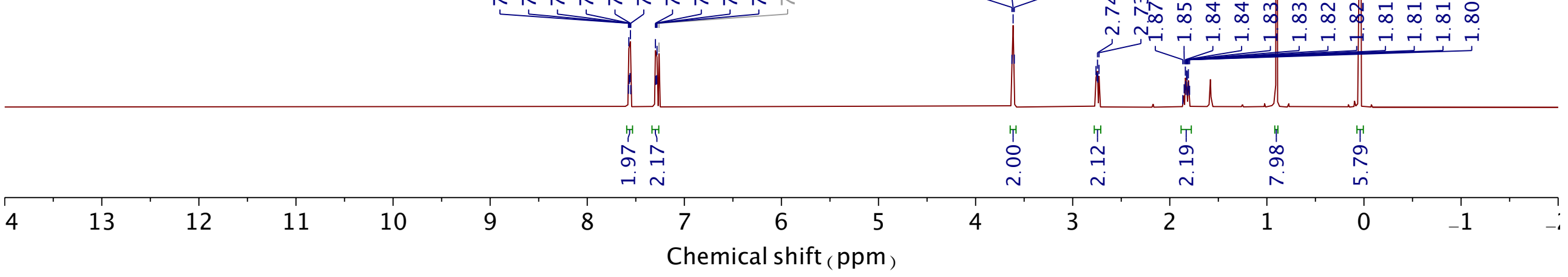

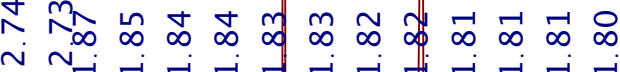




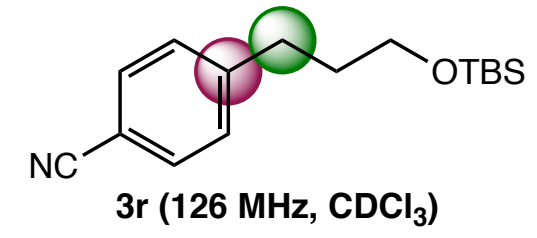

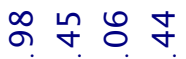

$m i \infty$

$3 r\left(126 \mathrm{MHz}, \mathrm{CDCl}_{3}\right)$
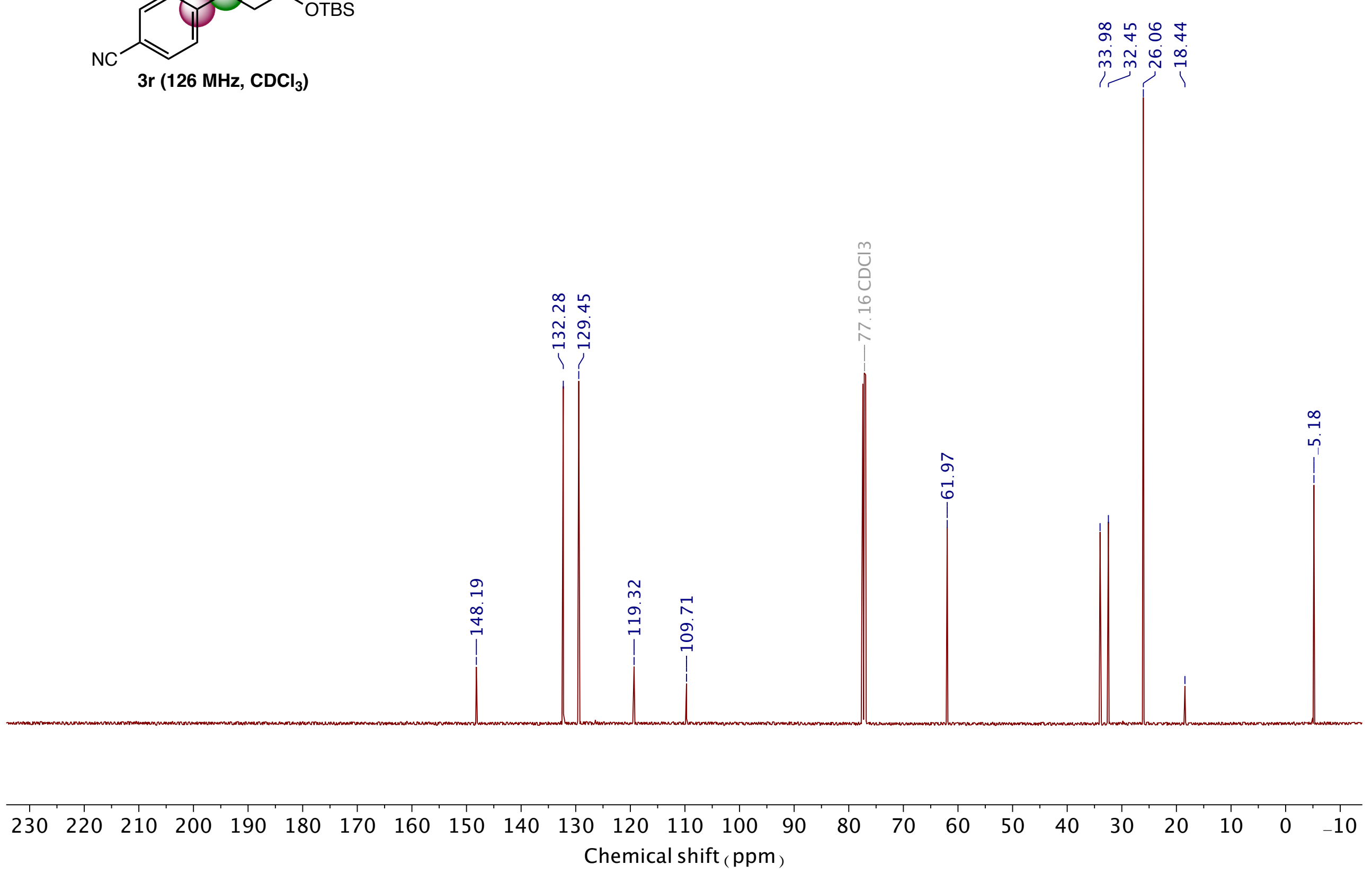


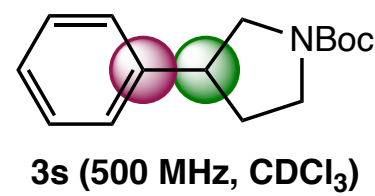

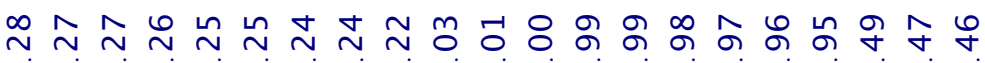

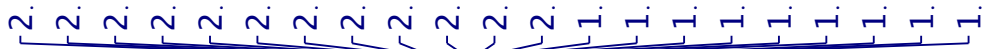

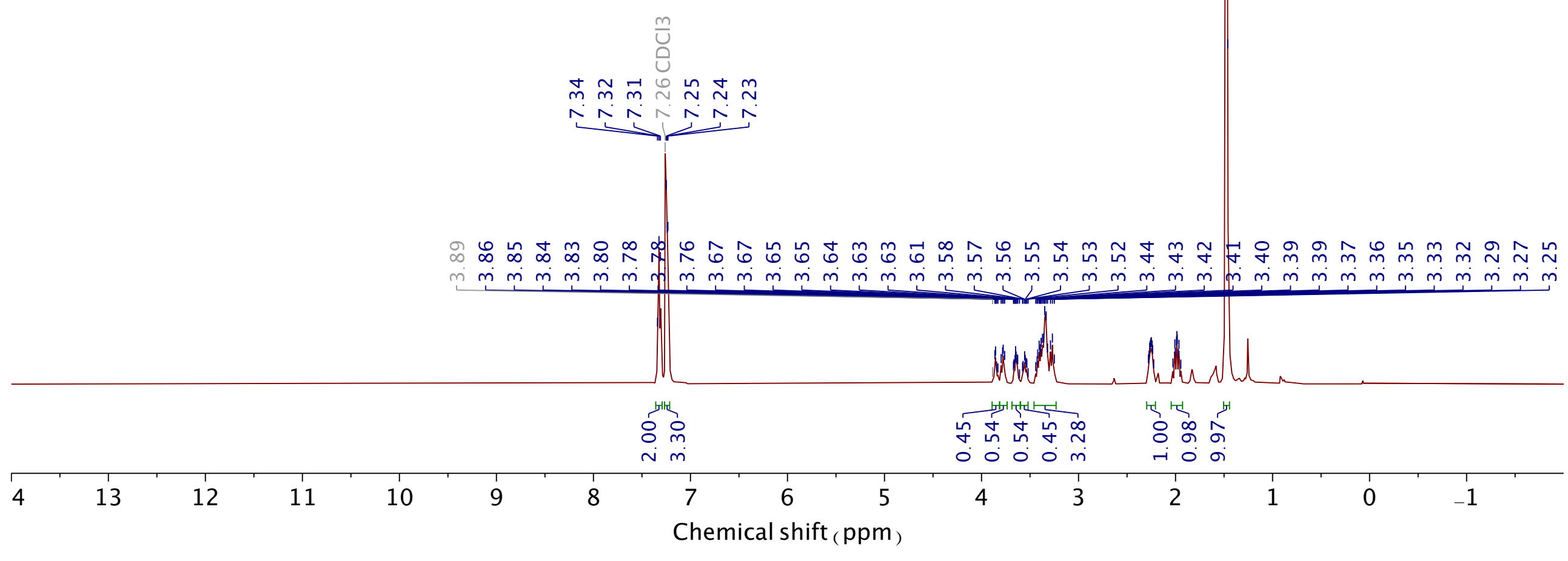




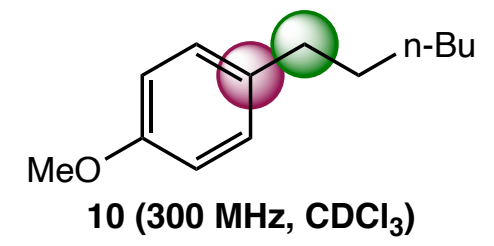

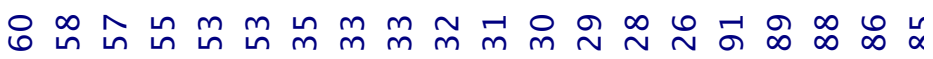

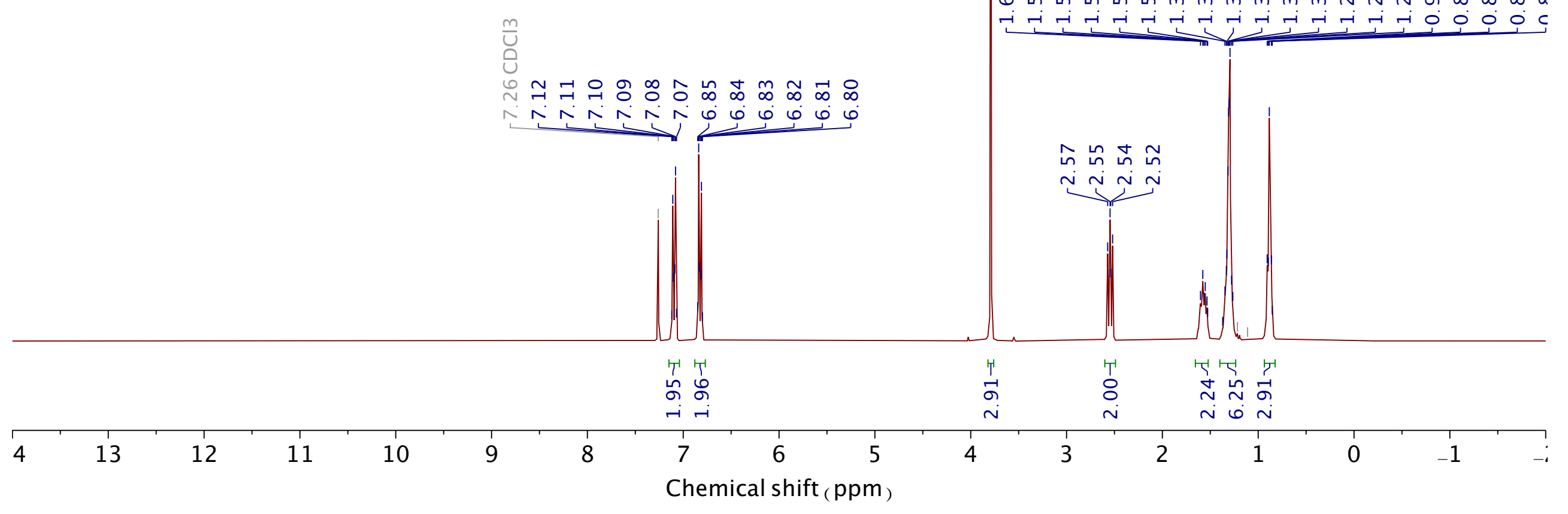




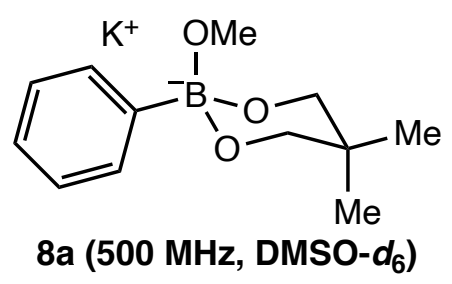

मे $m m m$ r

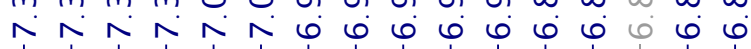

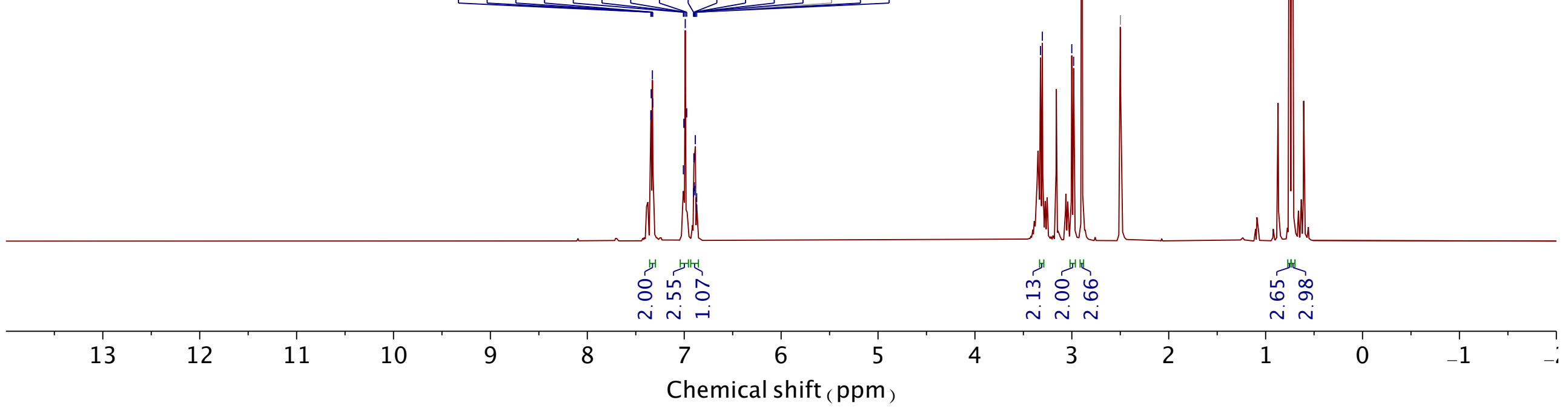




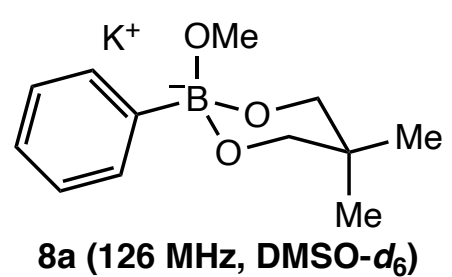

๙

$\tilde{m} \stackrel{m}{\sim}$

각

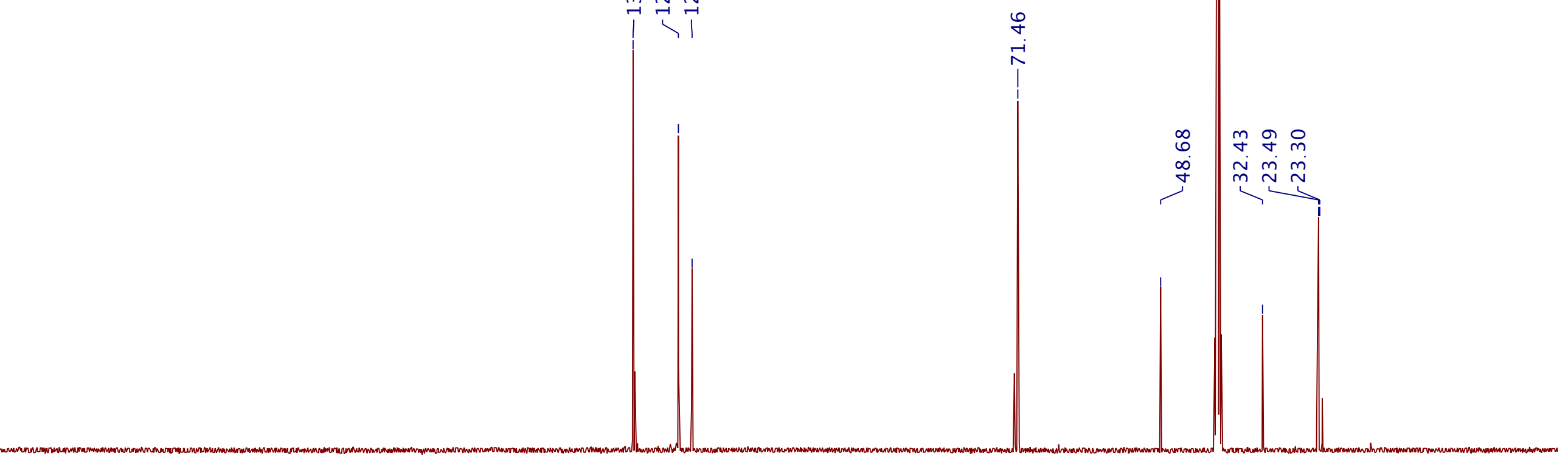

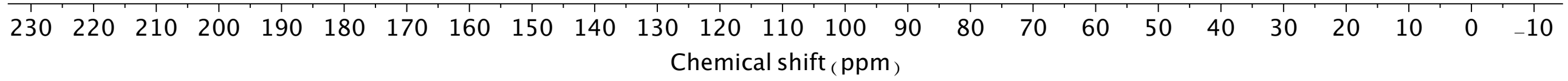




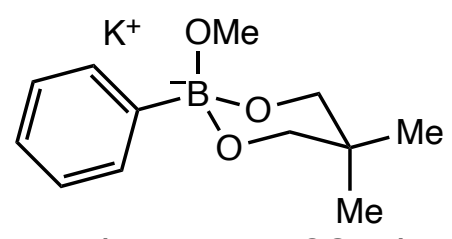

8a (96 MHz, DMSO- $d_{6}$ )

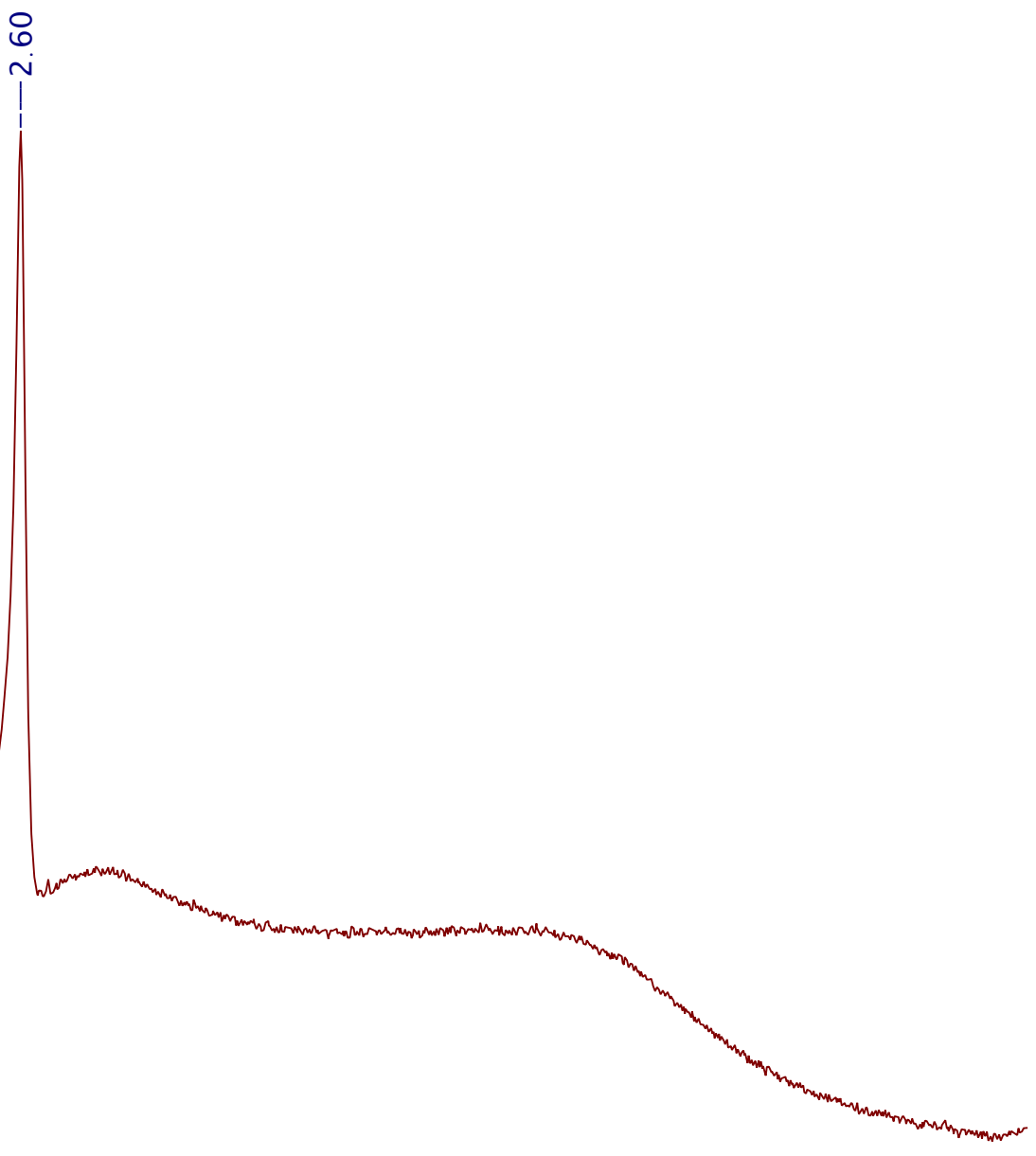

70

$60 \quad 50$

40 Chemical shift ( $\mathrm{ppm}$ 

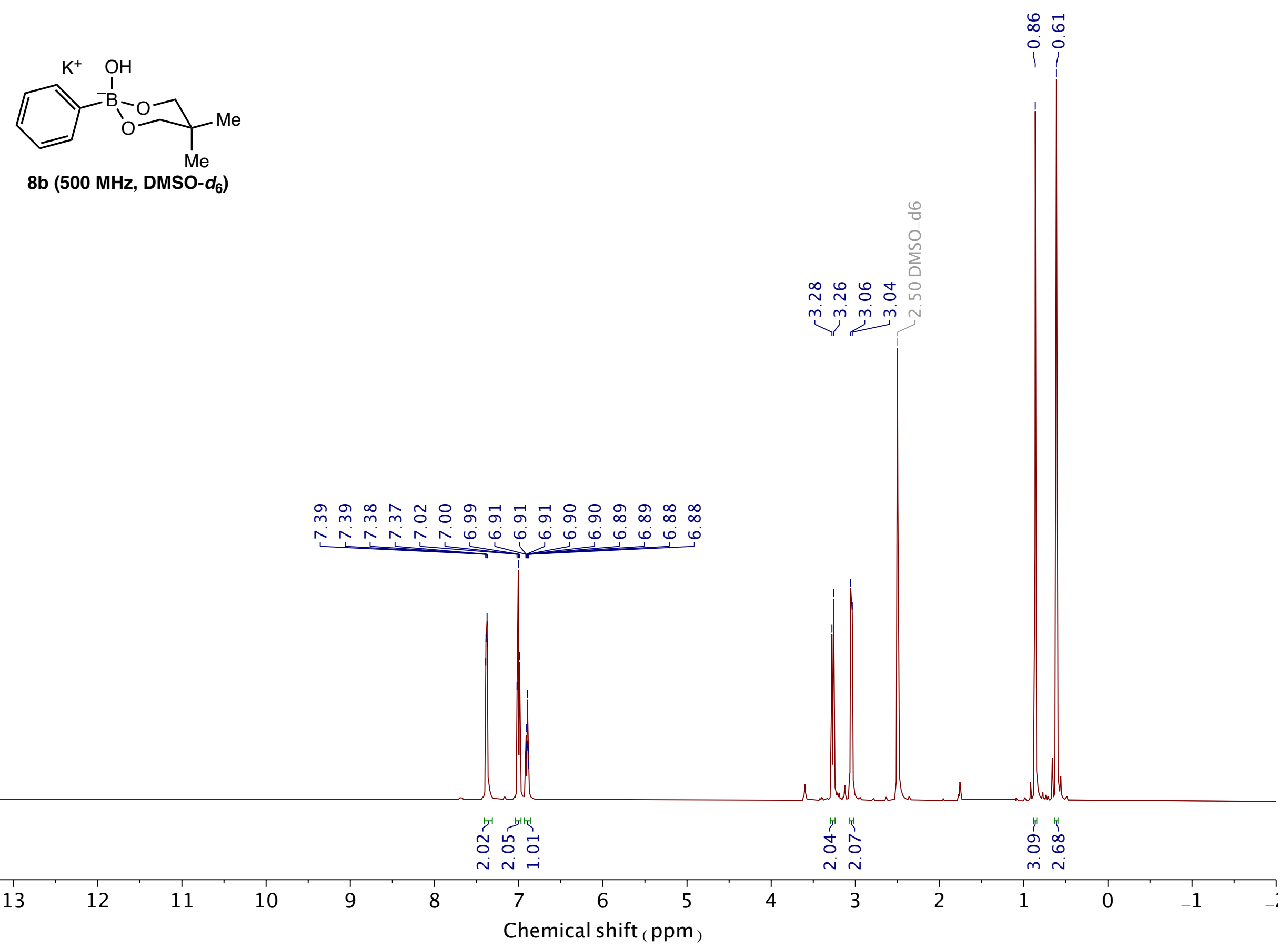


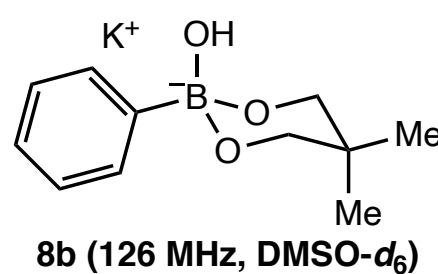

กิ

m $\stackrel{m}{\sim}$

m

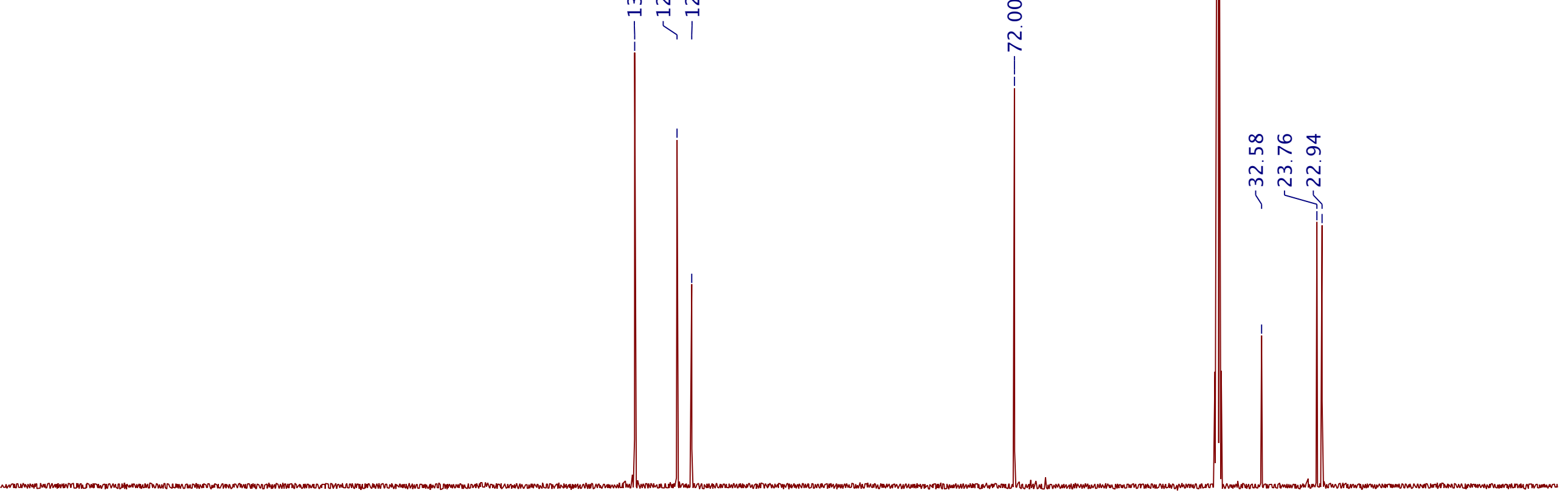

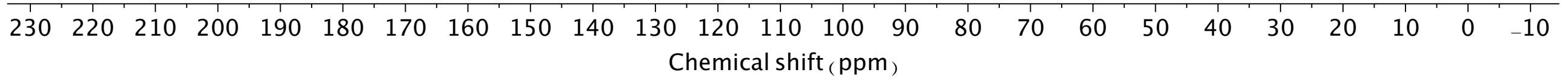




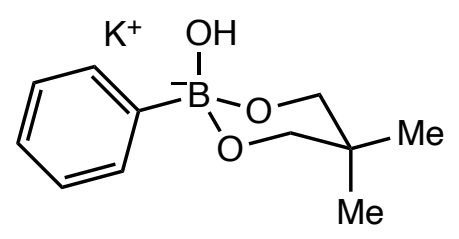

8b (96 MHz, DMSO- $d_{6}$ )

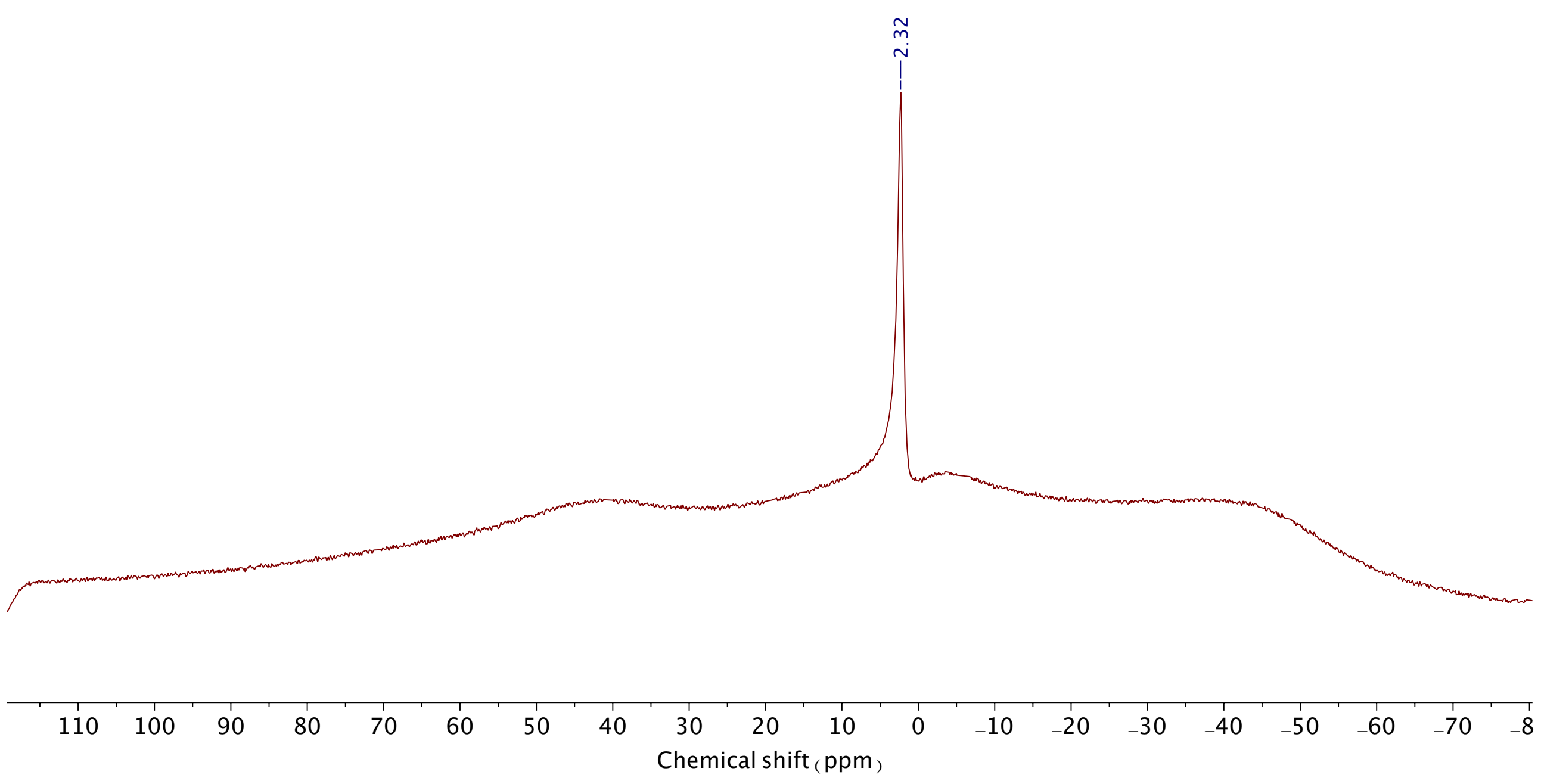

